\title{
Kernos
}

Revue internationale et pluridisciplinaire de religion grecque antique

25 | 2012

Varia

\section{Epigraphic Bulletin for Greek Religion 2009}

(EBGR 2009)

\section{Angelos Chaniotis}

\section{Q OpenEdition \\ 1 Journals}

\section{Electronic version}

URL: http://journals.openedition.org/kernos/2117

DOI: 10.4000/kernos.2117

ISSN: 2034-7871

\section{Publisher}

Centre international d'étude de la religion grecque antique

\section{Printed version}

Date of publication: 26 October 2012

Number of pages: 185-232

ISSN: 0776-3824

\section{Electronic reference}

Angelos Chaniotis, « Epigraphic Bulletin for Greek Religion 2009 », Kernos [Online], 25 | 2012, Online since 20 November 2014, connection on 15 September 2020. URL : http://journals.openedition.org/ kernos/2117 


\section{Epigraphic Bulletin for Greek Religion 2009 (EBGR 2009)}

The 22nd issue of the Epigraphic Bulletin for Greek Religion presents a selection of the epigraphic publications of 2009 and some additions to earlier issues. Following the practice of the most recent issues, emphasis was placed on the presentation of new corpora and editions of new texts, rather than on summarizing books or articles that use epigraphic material. Due to demanding research and administrative duties, this year I have been unable to complete the survey of journals on time. In order to avoid delays in the publication of Kernos, I could only present part of 2009's publications. This issue contains several very interesting new epigraphic finds. I would like to highlight the new fragments that have been added to the philosophical inscription of Diogenes of Oinoanda (65). They make possible the reconstruction of a large passage, in which the Epicurean philosopher rejects the idea that the fear of the gods prevents mortals from committing acts of injustice. Two very important new finds come from Aigai in Aiolis (98). One of them provides details on the cult of Seleukos I and Antiochos I, the other is the first attestation of an agonistic festival in Thessaly: the Olympia (98). A new copy of the Isis aretalogy was found in Kassandreia (70). Thanks to epigraphic finds the cult of Apollon Meleatas is now attested in Messenia (Asine?, 95) and that of Asklepios in Phthiotis (46); the sanctuary of Herakles in Thebes has now been identified, near the Elektrian Gates (11). New epigraphic material from Metropolis in Ionia provides information on the organization of the cult of Ares, which may be of local origin (53). The number of inscriptions from the sanctuary of Apollon Lairbenos, recording the dedication of slaves and free individuals by members of their family has been increased (4; cf. EBGR 2008, 1). One of the texts records the dedication of a man by his brother upon a dream. From this sanctuary we also have a new record of divine punishment. New texts are added to the increasing corpus of epigraphic visions of the afterlife. The most interesting, and at the same time most puzzling, comes from Athens (121): according to the most likely explanation of the verses, a woman met her dead daughter in the Elysium after her own death and thanks to her initiation in the Eleusinian mysteries. A funerary epigram from Crete (10) asks 'Diogenes', the son of Zeus (Hermes?), to send a woman to the place of the pious in the underworld because of her virtuous life (10; see also 26).

The principles explained in Kernos 4 (1991), p. 287-288, and Kernos 7 (1994), p. 287, also apply to this issue. Abbreviations that are not included in the list are those of L'Année Philologique and J.H.M. STRUBBe (ed.), Supplementum Epigraphicum Graecum. Consolidated Index for Volumes XXXVI-XLV (1986-1995), Amsterdam, 1999, as well as of later volumes of the SEG. If not otherwise specified, dates are BCE. Michael Anthony Fowler (Columbia University) has improved the English text. 


\section{Abbreviations}

AST 24

AST 25

Donateur, offrande, déesse

Estudios de Epigrafía Griega

Festschrift Schwertheim

Greek History and Epigraphy

KST 28

KST 29

KST 30

Meletes Habicht

Norme - - religieuse

Pathways to Power

Sacrifice antique
Arastirma Sonuclari Toplantisi, 29 Mayis-2 Hąiran 2007, Canakkale 2006, Ankara, 2007.

Arastirma Sonuçlari Toplantisi, 28 Mayis-1 Haziran 2007, Ankara, 2008.

C. PrÊTRE (ed.), Le donateur, l'offrande et la déesse. Systèmes votifs dans les sanctuaires de déesses du monde grec. Actes du 31e colloque international organisé par l'UMR Halma-Ipel (Université Charles-deGaule/Lille 3, 13-15 décembre 2007), Liège, 2009 (Kernos, Suppl. 23).

A. Martínez Fernández (ed.), Estudios de Epigrafía Griega, La Laguna, 2009.

E. WINTER (ed.), Vom Euphrat bis zum Bosporus. Kleinasien in der Antike. Festschrift für Elmar Schwertheim zum 65. Geburtstag (Asia Minor Studien, 65), Bonn, 2008.

L. Mitchell - L. Rubinstein (eds.), Greek History and Epigraphy. Essays in Honour of P.J. Rhodes, Swansea, 2009.

28. Kazı Sonuclar Toplantısı, 29 Mayis - 2 Haziran 2006, Canakkale, Ankara, 2007.

29. Kaz̨ Sonuclar Toplantısı, 28 Mayis - 1 Haziran 2007, Kocaeli, Ankara, 2008.

30. Ką̧ Sonuçlari Toplantısı, 26-30 Mayis 2008, Ankara, Ankara, 2009.

N. Themos - N. Papazarkas (eds), 'A

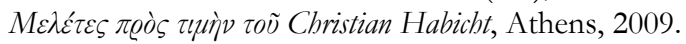

P. BRULÉ (ed.), La norme en matière religieuse en Grèce ancienne (Kernos, suppl. 21), Liège, 2009.

A.D. RizAKIS - F. CAMia (eds), Pathways to Power. Civic Elites in the Eastern Part of the Roman Empire. Proceedings of the International Workshop Held at Athens, Scuola Archeologica Italiana di Atene, 19 December 2005, Athens, 2008.

V. MEHL - P. BRULÉ (eds), Le sacrifice antique : vestiges, procédures et stratégies, Rennes, 2008.

\section{Selected Topics}

Geographical areas (in the sequence adopted by SEG)

Attica: Athens: 17. 23. 30. 34. 36. 37. 45. 55-57. 69. 76. 79. 83. 84. 92. 96. 97. 107. 109. 118. 120-122. 130. 132. 148. 152. 159. 160. 175; Eleusis: 6. 40. 109. 145; Salamis: 114.

Peloponnese: Aigina: 117. Corinthia: Sikyon: 75. Argolis: Argos: 35. 111. 128. 138. Epidauria: Epidauros: 58. 132. 164. Lakonia: 85. 179; Sparta: 179. Messenia: 51. 95. Arkadia: Eua: 160. Achaia: 8. Megaris: Megara: 139. Boiotia: 145; Lebadeia: 81; Oropos: 69; Thebes: 11; Thespiai: 163. Aitolia: Kalydon: 102; Thermon: 82. Delphi: 82. 94. 124. Phokis: Antikyra: 135; Ambryssos: 135; Kalapodi: 133. Phthiotis: Daphnous: 46. Thessaly: 98; Magnesia: 61; Melitaia: 29; Pelinna: 104; Pherai: 20. 58. Illyria: Epidamnos: 108. Macedonia: 38; Akrothooi: 112; Amphipolis: 172; Aphytis: 1; Beroia: 7; Bragylos: 113; Dion: 116; Kalindoia: 151; Kassandreia: 170; Leukopetra: 31; Styberra: 156; Thessalonike: 
158. Thrace: 47; Maroneia: 119. 143; Mesabria: 141. Moesia: Dionysopolis: 13; Histria: 13. 14. North Shore of the Black Sea: Berezan: 13. 24. Delos: 34. 54. 66. 173. Rhodes: 26. 50; Lindos: 63. 64. 89. Thera: 70. 150. Kos: 98. Naxos: 18. Kythnos: 40. Andros: 124. 125. Imbros: 41. Thasos: 112. 148. Euboia: Oreoi: 144; Zarax: 62. 100. Crete: Aptera: 16; Gortyn: 93; Lappa: 169; Lato: 129; Lato pros Kamara: 10; Lebena: 132; Phalasarna: 86; Syvritos: 168. Italy: Rome: 132; Sicily: Selinous: 139. Pannonia: Aquincum: 19. Noricum: 67. Spain: 12. 42. 134. Asia Minor: 33. 49. Karia: Halikarnassos: 61; Iasos: 21. 166; Knidos: 31. 115; Labrauda: 76; Lagina: 138. Ionia: Didyma: 101. 165; Ephesos: 27; Magnesia on the Maeander: 98. 138. 167; Metropolis: 53; Miletos: 13. 126. 165; Priene: 157. Lydia: 5. 132. 137; Sardeis: 127; Tripolis: 161. Aiolis: 98; Aigai: 98; Kyme: 143. Troas: Lampsakos: 138. Mysia: 137; Parion: 52; Pergamon: 59. 103. 132. 157. Bithynia: Bithynion: 2; Kalchedon: 157; Kios: 138. Pontus: Herakleia Pontica: 78. Galatia: 106. Phrygia: 137; Aizanoi: 178; Hierapolis: 4. Pisidia: Pednelissos: 157. Lykia: Arykanda: 71. 72; Kibyra: 43. 44. 132; Oinoanda: 65. 153; Xanthos: 15. Cyprus: 9. 60. Kommagene: 3; Doliche: 22. IsraelPalestine: Jerusalem: 48. Egypt: 39. 146. Kyrene: 91. 99

acclamation: 33.49 .67 .171

account: 118

afterlife: 5. 10. 13-14. 20. 26. 57. 78. 121. 137. 145. 161; see also Greek words.

agonistic festival: 147; Antinoeia 76 (Athens); Antoneia 76 (Athens); Attalianeia Olympia 161 (Tripolis); Basileia 81 (Lebadeia); Germanikia 76 (Athens); Hadrianeia 76 (Athens); Olympia 98 (in Thessaly); Pythia 94; Rhomaia 11 (Thebes); Trophonia 81 (Lebadeia); founding of: 161; see also festivals

altar: 2. 98. 138. 146; funerary: 71

amphiktyony: 34

amulet: 67. 134. 171

anatomical votive: 4.149 .174

animal, in Orphic ritual: 104; see also sacrificial animal

Antiochos I of Kommagene: 3

aretalogy: 119. 143. 170

association, cult: 7. 18. 114. 120. 127; see also Greek words

banquet: 21. 61. 143; funerary: 145

benediction: 171

calendar: 35 (Argos). 136 (Aphrodisias)

cave, cult: 1

cession of property to gods: 33

change, religious: 54.109

Christianity: 48; magic: 140; and pagan images: 50; crypto-Christian: 2

clothes, dedication of: 54.73 ; restrictions: 138

commemorative inscription: 93

confession: 4. 33. 49

cult, of daimon of an individual: 138, ruler cult: 3. 9. 98. 146. 172

cult, development: 54; founder of: 173; introduction: 25. 54. 175; reform: 3; transfer of: 13 . 14. 40. 139. 142. 143. 172

cult personnel: agonothetes: 2. 11. 57. 76. 161; agoranomos: 7; archiereia 156; archiereus of the imperial cult: 2. 44. 75; in Achaia: 30; in Galatia provincial: 106; arrhephoros 37; 
athlothetes 161; diakonos 53; episkopos 34; epitropos 34; hiereia (priestess) 14. 53. 54. 57. 76. 145. 157. 162; hiereus (priest) 33. 36. 38. 53. 63. 64. 93. 95. 103. 106. 114. 120. 138. 151. 172; hierokeryx 98; hieropoios 34. 83. 159; hierothytes 179; hierourgos 93; hypostolos 172; neokoros 34; neopoioi 136; odrogos 53; phytourgos 88bis; pyrphoros 56. 57; sebastophantes 2 ; sebastophoroi 90 ; tamias 17 ; zakoros 57 ; for life: 57 ; iteration: 179; ritual expert: 53. 72. 157; slave: 53

curse: 33. 110. 138; curse tablet: 12. 19. 48. 60. 87. 117. 135; cf. s.v. imprecation; see also Greek words

daimon of an individual: 138

dedications: 54.73 .129

dedications, by choregos: 96; by ephebes: 69; by priest/priestess: 14. 15. 36. 54. 64. 103. 131; by soldier 47 ; through a relative: 47 , by women: 31.73 .131

dedication, after agonistic victory: 96. 97. 126; after miracle: 13; after war: 129; for the emperor: 57. 146; for family members: 14. 18. 36. 103; as a tithe: 21; upon divine command: 78. 146; upon dream: 4. 31

dedications, of clothing items: 54. 73; of family members: 4; of footprints: 116; of kernoi: 40; of a mirror: 85 ; of slaves: 4. 31; see also s.v. anatomical votive

deification: of Roman benefactor: 163; see also s.v. cult (ruler cult), imperial cult

deities: Ammon: see Zeus. Agathos Daimon: 145. 146. 171. Amphiaraos: 69. Aphrodite: 18. 54. 70. 129. 136. 145. 146. 150. 174; Dosandra 174; Epiteleia 174; Euakoos 145; Pontia 84; Stratagis 174; Nomophylakis 174. Apollon: 14. 24. 26. 28. 35. 88bis. 91. 98. 101. 133. 137. 167; Agyieus 70. 141; Boreas 14; Delios 34. 62. 100; Ekebolos 62?; Ietros 14; Karneios 70. 115; Kerdoios 98; Klarios 138; Korythos 51; Kyrios 2; Lairbenos 3; Lykeios 70. 165; Maleatas 95; Pholeuterios 14; Pythios 151; Sykiessenos 103; see also s.v. Helios. Ares: 53. 117. 150. Artemis: 2. 14. 64. 102. 108. 120. 145; Agrotera 135; Aontia 8; Aspalis 29; Astias 21. 166; Boulaia 165; Chitone 165; Eileithyia 135; Epipyrgidia 165; Hagemona 151; Hekate 108?; Limnatis 85; Lochie 165; Lykeie 165; Orthia 135. 179; Paidotrophos 135; Patmia 165; Promathes? 135; Pythie 14. 165; Soteira 135. 150. Asklepios: 16. 29. 36. 46. 109. 130. 149. 151. 154. 171. 175; Soter 103. 116. Athena: 41. 57. 70. 118; Assesie, Hippia 97; Latmia 28; Lindia 63. 64. 89; Polias 23. 146; Soteira 98. Auxesia: 70. Boreas: 70. Charites: 70. Chiron: 70. Damia: 70. Demeter: 2. 20. 23. 40. 76. 121. 145. 162; Achaia 57; Chthonia 58; Horephoros 155; Karpophoros 155; Kourotrophos 57?; Malophoros 155; Pyrphoros 155; Thesmia 155; Thesmophoros 155. Dionysos: 1. 7. 9. 145. 151. 168; Bakechos 20; Patroios 139. Dioskouroi: 70. 91. 99. 152. Enyalios: 51. 150. Erinyes: 70. Ge: Kourotrophos 57? Eukleia: 109. Eunomia: 109. Hades: Dekter 70?. Hagne Thea: 148. Hekate: 108. Helios: 64. 137. 171; Apollon 4; see also Zeus. Hephaistos: 117. Hera: 35. 47. 111. Herakles: 6. 11. 44. 50. 80. 122. 144. 145. 148. 172; Alexikakos 78. Hermes: 10. 66. 70. 128. 151. Hosia Dikaia: 137. Hosios: 2. Hosios kai Dikaios: 137. Hydreios: 149. Hygieia: 103. 130; Isis 149. Iupiter Dolichenus: 22. Kore: 2. 23. 40. 70. 76. 121. 145. 162. Kores: 70. Kybele: 145. Leto: 13. 14. Megaloi Theoi: 41. Mes: 137. Meter: Makaria Hosia Dikaia 173. Meter Oreia: 20. 58. 126. Meter Theon: 2. 120. 164. Moira: 42. Mousai: 42. 64. Nemesis: 134. 153. 169. Nymphs: 57. 86. Pan: 128. 145. Plouton: 2. Poseidon: Erechtheus 23; Gaiaochos 70. Prometheus: 135?. Rhome: 151. 158. Tauros: 163. Xanthos: 15. Zeus: 2. 47. 61. 117. 137. 151. 171. 178; Akraios 61; Ammon 1; Dekter 70; Eleutherios 75. 109. 146. 158. 179; Epopetes 120; Helios Sarapis 170; Hikesios 70; Keraunios 112?; Labraundos 76; Megistos 43; Meilichios 139. 145; Nephalios 120; Olympios 98. 161; Ouranios 112; Pelorios 70; Polieus 63. 64. 70; Sarapis 67; Soter 2. 75. 98. 146. 
deities: Babylonian: Nenaia: 151; Egyptian: 25. 36. 38. 39. 52. 67. 109. 119. 130. 134. 138. 143. 146. 149. 157. 170-172; Roman: Iuno Regina: 47; Iupiter Optimus Maximus: 47; Mercurius: 66; Thracian: Bendis: 114

deities, confirm an arbitration: 120; personal relationship with worshipper: 2. 173; patrons of agriculture: 127. 155; of healing: 132. 149; of household: 150; of magistrates: 54. 129. 174; of marriage: 54.174 ; of seafaring: 174 ; of sexuality: 174; of war: 51 ; of water: 144 ; protection from winds: 8 ; wrath of 31.33

destiny: 27.42

Dionysiac artists: 9. 55. 147

disease, as punishment: 4

dream: 4. 31. 145; dream interpreter: 149

elite: 30. 109. 151

emotion: 31.171

encomium, for god: 119

epiklesis, deriving from ritual: 120: list of: 135

epiphany: 89

epithet: see s.v. epiklesis

exaltation of god: 33.49

exorcism: 140

fear of god: 65

festival, announcement of honors: 138. 177; recognition of: 98

festivals: 124. 125; Amphiaraia 69; Compitalia 66 (Delos); Delia 34; Dionysia 45. 98. 168 (Syvritos). 177; Lenaia 92; Panathenaia 45. 57. 97. 109; Panhellenia 147 (Athens); Pythia 55;

Soteria 124 (Delphi); Thesmophoria 40; see also agonistic festival

finances of cult: 17. 34. 105. 118. 127. 159

footprints, dedication of: 116

funerary cult: 71. 125. 145. 160; cf. s.v. grave, imprecation

gem: 67.171

grave, protection of: 5.136

grove: 61

healing: 4. 132. 149

hero: Aleximachos: 145; Meleagros: 128; Polemokrates: 128; Thessalos: 98

heroic cult: 11. 75. 113. 145. 148. 159

historiola: 117

hymn: 24. 164

identity: 88. 95.123

imperial cult: 2. 30. 43. 44. 57. 75. 90. 106. 109. 136. 151. 156. 158. 166; emperor associated with a god: 75 (Nero-Zeus Eleutherios). 109 (Iulia Domna-Athena Polias). 146 (Augustus-Zeus Eleutherios). 179 (Antoninus Pius-Zeus Eleutherios)

impiety: 136

imprecation, funerary: 5

incense: 138; incense burner: 101. 126

initiation: 41. 121. 145

instruction: 4 
inventory: 41.131

invocation: 67.70 .170

Jews: 67

kernos: 40

kinship, mythological: 98

Korybantes: 61

Kouretes: 61

libation: 98.127

magic: 48. 59. 140. 171. 180; historiola: 117

Maron: 50

Minos: 10

miracle, healing: 132

month, named after deified king: 98; after emperor: 136

mystery cult: 41. 61. 121. 127

mythology: 11. 13. 29. 61. 86. 117. 142; and Christianity: 50; exempla in epigrams: 142; kinship based on myth: 98

name, theophoric: 14.39

norm: 32.88

oath: 79.93

oracle: 28. 124. 138. 167. 171

Orphics: 20.58. 68. 104

papyri, magical: 59. 140. 180

perfume, in cult: 101

personification: 82 (Aitolia). 109 (Eukleia, Eunomia)

philosophy: 65.68

piety: 2. 31. 76. 109

politics and religion: 25.34 .107

prayer: 33.98 .127

prayer for justice: 31

priesthood: accumulation of offices: 2; appointment: 23. 28; cursus honorum: 64; election: 28; family members: 53.75 ; health: 176 ; hereditary: 23.75 .157 ; iteration: 2.38 .53 ; for life: 28.75 .109 . 138; list of priests: 151; perquisites: 148 ; protection of authority: 157; sale: 28

priests, as arbitrators: 33 ; eponymous: 13 ; insignia of: 98 ; promise of donation: 106 ; see also cult personnel

procession: 24. 90.91.138

prophet: 2

punishment, divine: 4. 31. 33. 49

purification: 33.34 .101

rain: 61

regulation, cult: 32.88 .110 .138 .176

Rhadamanthys: 10

rider god: 80 ; rider hero: 145 
ritual: 32. 33. 88bis; see s.v. acclamation, banquet, exaltation, initiation, libation, prayer, procession, purification, sacrifice, vow

sacrifice: 61. 72. 74. 93. 98. 101. 127. 138. 148. 149. 159. 180; funding of: 6. 120. 148; bekatombe 98 ; holokautesis 148. 154; honorary share of victim's meat: 74

sacrificial animal: bull: 98; ram: 138; cutting of: 148; for Asklepios: 154; price of: 120

sanctuary 49; access: 120; administration: 34 ; boundary stone of: 120; economic activities:

34; fees for: 33. 41; finances: 105. 118. 120; fine paid to: 93. 136; foundation: 25; and justice: 33; privileges of: 88bis. 178; property: 34. 120; publication of documents in: 107; revenues of: 6; see also s.v. inventory

sin: 33.49

slave, as ritual expert: 53

society: 30

soul: 65.68

statue, cult: 98 ; decoration of: 136

syncretism: 66.171 .173

theoria: 34.72

tradition: 109

tree, in ritual: 88 bis. 167

vision: 145

vow: 47. 52. 76. 80. 103. 126. 137. 169. 172; see also Greek words/dedications s.v. sủxウ́

women: 4. 31. 40.73. 131

\section{Greek words (a selection)}

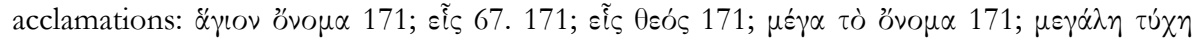

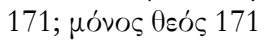

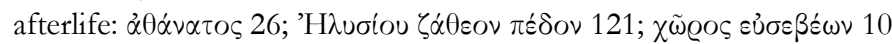

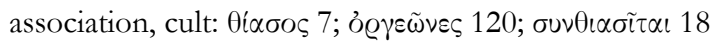

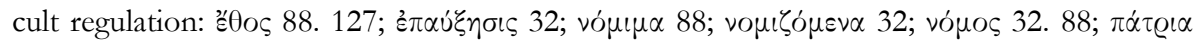
32. 88

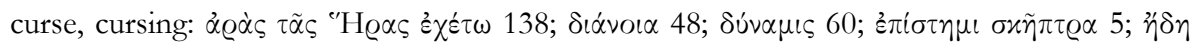

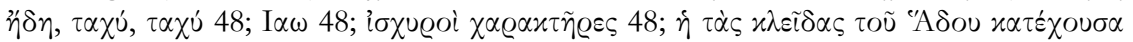

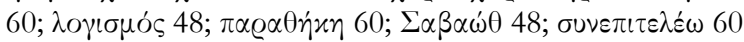

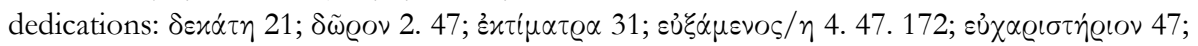

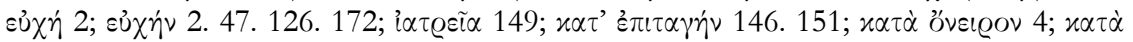

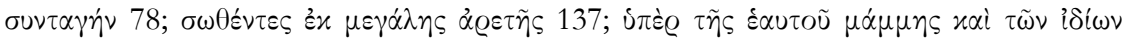

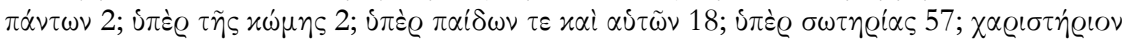
103. 172

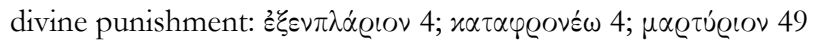

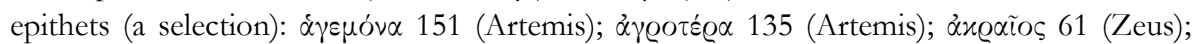

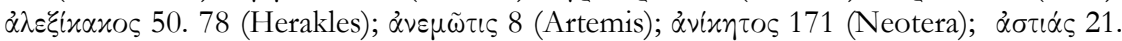

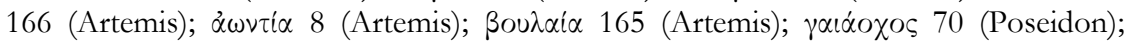

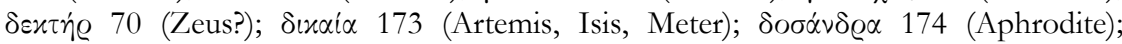
छ่̇

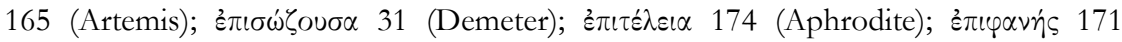

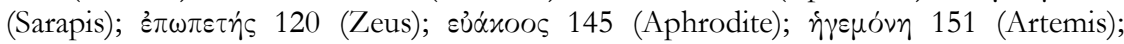

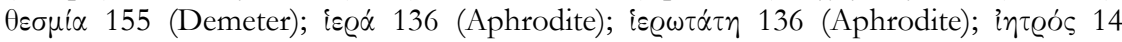




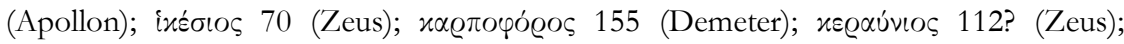

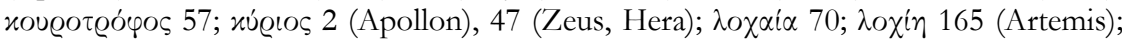

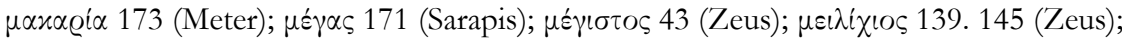

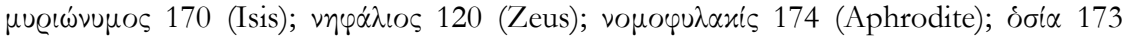

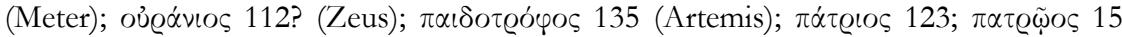

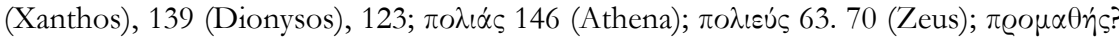

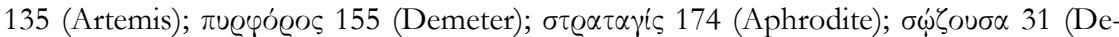

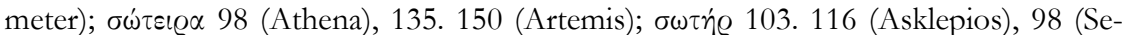

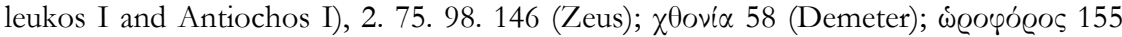
(Demeter)

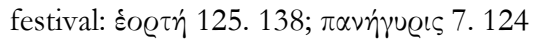

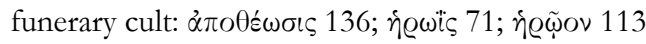

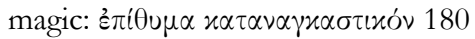

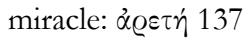

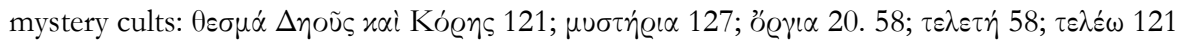

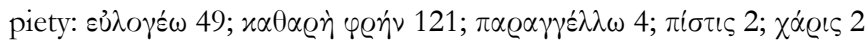

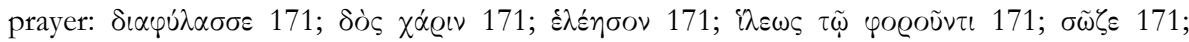
$\varphi \dot{\lambda} \lambda \alpha \sigma \sigma \varepsilon 171$

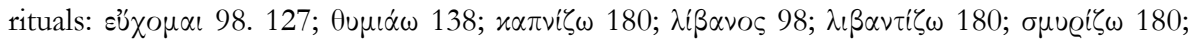

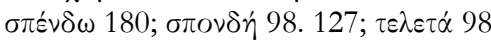

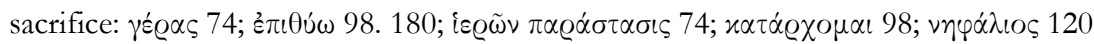

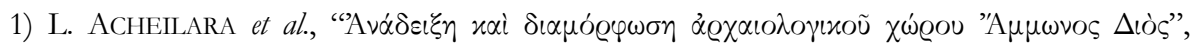
AEMTh 22 (2008) [2011], p. 419-426 [SEG LVIII 554]: The A. report on recent archaeological work in the area of the sanctuary of Zeus Ammon at Aphytis (Chalkidike). The finds include a fragmentary inscription discovered near the temple [perhaps to be restored as [- - $\Theta]$ soũ |

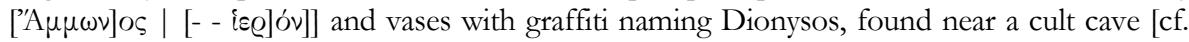
EBGR 2000, 209].

2) M. ADAK - N.E. AKYÜREK ŞAHIN - M.Y. GÜNEŞ, "Neue Inschriften im Museum von Bolu (Bithynion/Klaudiupolis)", Gephyra 5 (2008) [2009], p. 73-120 [BE 2010, 560-561; SEG LVIII 1417, 1421-1429, 1431, 1454]: Ed. pr. of inscriptions from Bithynion/Klaoudioupolis and the surrounding area. If not otherwise stated, the inscriptions date to the 2 nd and 3 rd cent. CE. A man who served three times as high priest and occupied among other offices those of the agonothetes (at his own expense) and the sebastophantes, paid the cost of an honorific statue for his dead son, who was honored by the council and the people (2) [on the office of the sebastophantes see EBGR 2005, 153]. A priest of Titus made a dedication to this emperor $(6 ; \mathrm{ca}$ 79-81). An agonothetes dedicated an altar (16). A couple dedicated two altars, to Meter Theon (8)

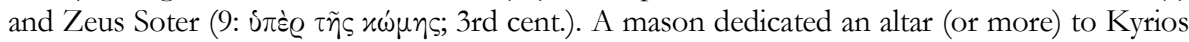

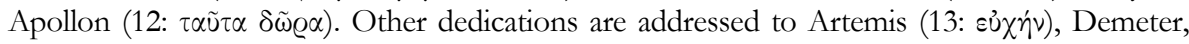

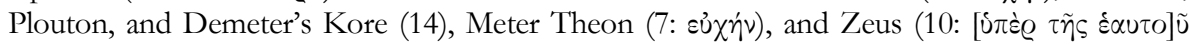

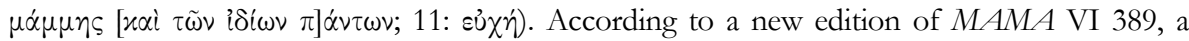
dedication was made to Hosios alone - not Hosios and Dikaios (15). The grave epigram for the poet Glykon praises him for his piety (17) [for an improved edition see G. STAAB, "Bemerkungen zu neuen metrischen Inschriften aus Bithynien", EA 43 (2010), p. 101f.]. A posthumous honorary epigram for Smaragdos was set up by his wife, who praises him with the

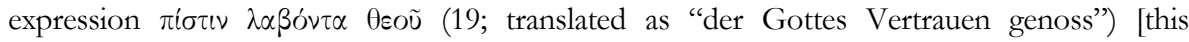


expression is ambiguous, leaving the nature of the close relationship between Smaragdos and 'god' unclear. Smaragdos could have been a prophet, but we cannot exclude the possibility that he was a crypto-Christian; in the latter case, the phrase should be translated as "who received/ accepted the belief of/in God"; cf. STAAB, supra, p. 105f.]. This epigram is almost identical to

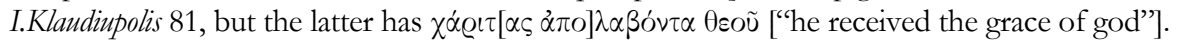

3) R. Aguilar, "Las inscripciones de Commagene", in Estudios de Epigrafía Griega, p. 297-304: Overview of the content of the inscriptions that record the cult reforms of Antiochos I of Kommagene and the establishment of a dynastic cult.

4) E. AKINCI ÖZTÜRK - C. TANRIVER, "Some New Finds from the Sanctuary of Apollon Lairbenos", EA 42 (2009), p. 87-97 [BE 2011, 567]: Ed. pr. of 23 inscriptions found in the sanctuary of Apollon Lairbenos northeast of Hierapolis [cf. EBGR 2008, 1]. They consist of four dedications (1, 3-5), one record of divine punishment (2), and 18 katagraphai (dedications of slaves; 6-23). Except for a Hellenistic dedication (1), the inscriptions seem to date to the 2nd and 3rd cent. CE. The texts are addressed to the god, whose epithet is given in different forms

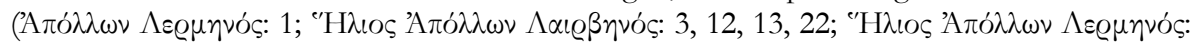

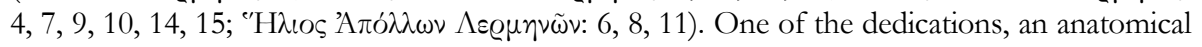
votive representing female breasts, seems to be connected with the expectation of a cure

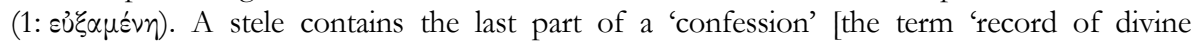
punishment' is preferable for this kind of text]: "[I was punished] on my buttock, I declare that nobody should disregard (the god), because he will find my stele as a (warning) example"

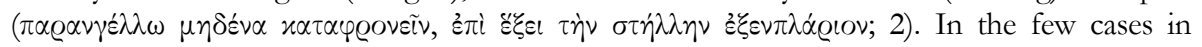
which the object of the katagraphe is preserved, it deals with alumni $(6-8,14)$ and relatives of the dedicants: their sons $(9,11)$ and in one case a brother of a dedicant $(10)$; in the latter case,

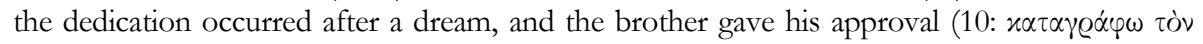

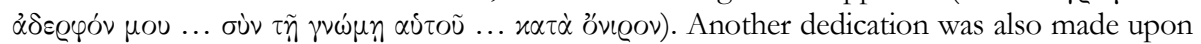

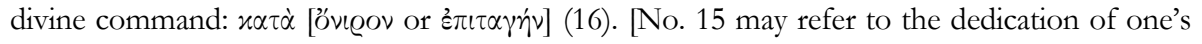

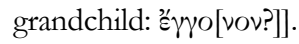

5) N.E. AKYÜREK ŞAHIN - F. ONUR, "New Funerary Inscriptions from Lydia in the Kütahya Museum”, Gephyra 5 (2008) [2009], p. 125-138 [SEG LVIII 1359]: Ed. pr. of a funerary

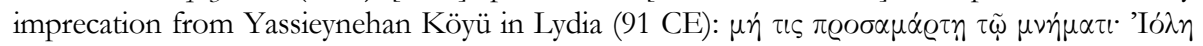

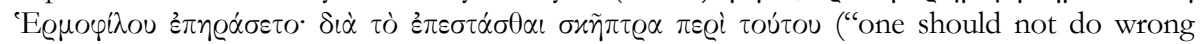
against the tomb; Iole, daughter of Hermophilos, imprecated by erecting [sacred] sticks all around this [tomb"]). [Reading and translation need to be improved in two respects. After the

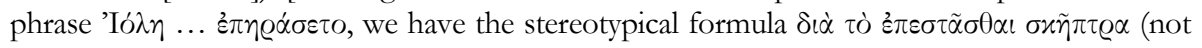

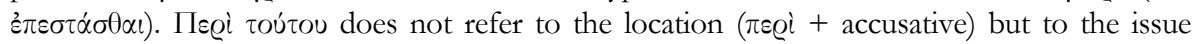
$\left(\pi \varepsilon \varrho^{i}+\right.$ genitive): "no one should wrong this tomb; Iole, daughter of Hermophilos, imprecated by erecting sceptres for this matter"; cf. G. PETZ, "Keine Szepter an Gräbern”, ZPE 177 (2011), p. 123-126. For a particular case of the erection of sceptres (not near tombs, but in

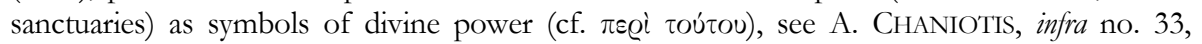

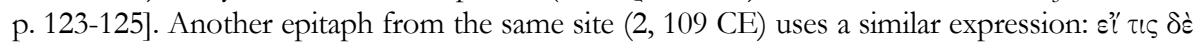

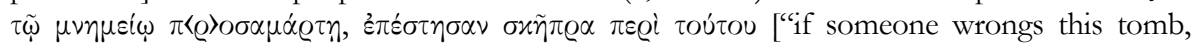
sceptres have been erected for this matter"].

6) S. AliPHerI, “The Eleusinian Decrees REG 91 (1978) 29-306 Reconsidered”, in Meletes Habicht, p. 183-192: A. republishes with commentary two decrees of the deme of Eleusis concerning the cult of Herakles in Akris (I.Eleusis 85). The first decree (chronologically) assigns the revenues from a stone quarry in Akris to a sacrifice for Herakles (332/1 BCE); the second decree honors the man who leased the quarry for five years. 


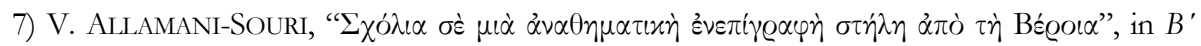

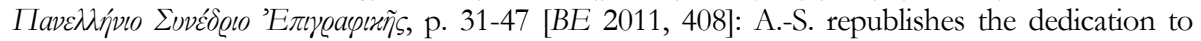
Dionysos by Paramonos, agoranomos of a thiasos, and the honorary inscription of the thiasos for Paramonos (Beroia, 7 BCE; I.Beroia 22; SEG XLVIII 751). On the relief, she identifies the man on the left as Paramonos, and the larger libating male figure on the right as Dionysos. The use

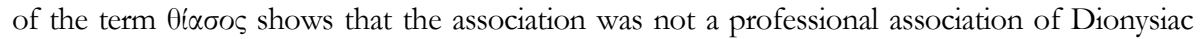

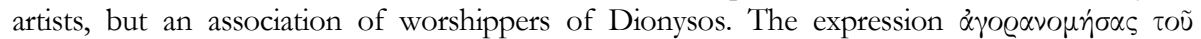
$\theta \iota \dot{\alpha} \sigma o u$ means that Paramonos exercised this function in the association (cf. SEG XI 50). The agoranomos of the thiasos was probably responsible for the festival (cf. the expression $\pi \alpha \sim \eta \gamma \dot{\varrho} \varrho \varepsilon \omega \varsigma$

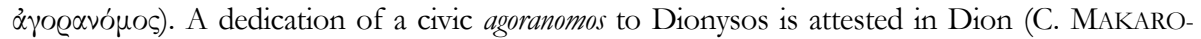

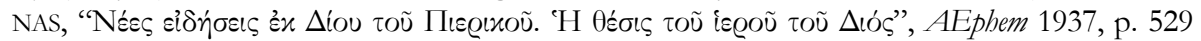

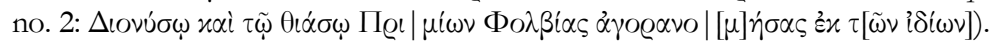

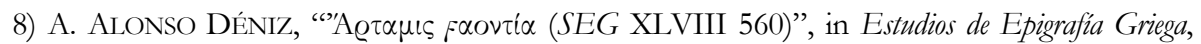
p. 113-118 [BE 2010, 255]: The A. discusses the etymology of Artemis' epithet Faovti $\alpha$, attested in Achaia (SEG XLVIII 560) [EBGR 2004, 213] and possibly related to ¿̋ $\eta \mu$ or * $\alpha_{F} \omega \nu$ (wind), associating the goddess with the winds. Artemis may have been the goddess who calms

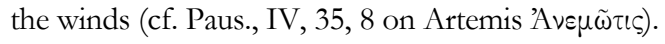

9) A. Anastassiades, "Behind Masks: The Artists of Dionysos in Ptolemaic Cyprus", RDAC 2009, p. 195-204: A. provides an overview of the organization and activities of the association of Dionysiac artists in Cyprus and comments on their relations to the Ptolemaic court and ruler cult. [For all of this, see the study of S. Aneziri, already summarized in EBGR 1993/94, 9, which the A. ignores].

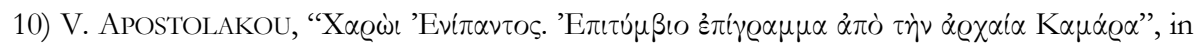
Estudios de Epigrafía Griega, p. 456-468: Ed. pr. of an interesting funerary epigram from Lato pros Kamara (East Crete, 3rd cent.). The text reports that the thirty-year old Charo died during labor, leaving grief to her mother, husband, and children. The most interesting feature of the text is an appeal in the last two verses to "Diogenes" (the son of Zeus) to send her to the place

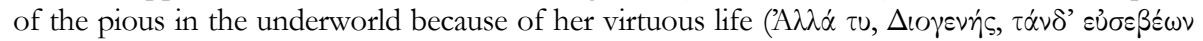

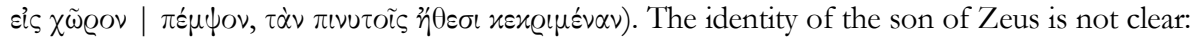
Hermes, typically regarded as psychopompos (e.g. I.Cret. I iv, 37; I viii, 34), or the (Cretan) judges of the underworld, Minos (GV 943) and Rhadamanthys (GV 1693).

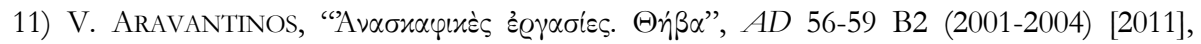
p. 124-159: Ed. pr. of an agonistic inscription that lists the winners at the Rhomaia (Thebes, late 2 nd cent.). The list gives the name of the agonothetes (Ismenias) and the winners of the following competitions: trumpeter, herald, epic poet, rhapsode, auletes, kitharistes, kitharodos, and satyr poet (130). On p. 133-134, A. reports on the results of an excavation at the sanctuary of Herakles in Thebes. The epigraphic finds consist of graffiti and dedications to Herakles and possibly to Megara, his wife.

12) M. ArbabZADAH, "A Note on the Bilingual Curse Tablet from Barchín del Hoyo (Spain)", ZPE 169 (2009), p. 193-195: A. discusses two expressions (devotos defixos and supra) in the Latin version of a bilingual curse from Fuente de la Mota in Spain (EBGR 1999, 47). Assuming that the Greek version was written first, A. interprets the Latin version as a reference to the individuals already cursed: "On behalf of me, on behalf of my house, those cursed, bound (people) to those below (devotos defixos), those cursed, bound (people) to those below, Time and Nikias and the others, all of whom rightly I have cursed above (supra), on behalf of me, on behalf of my family, Time, Nicias, Nicias." 
13) A. Avram, "Épigraphie et histoire religieuse : le culte de Léto dans les cités de la Mer Noire", in Estudios de Epigrafía Griega, p. 305-313 [BE 2010, 445]: A. republishes five inscriptions concerning the cult of Leto in the area of the Black Sea: a bone plaque from Berezan, which refers to Leto ( $\mu \varepsilon \dot{\mu} \mu \eta \eta \mu \alpha \iota \Lambda \eta \tau \tilde{(\varsigma)})$ IGDOP 93) [cf. infra no. 24], three dedications to Leto from Histria (I.Histriae 170; I.Histriae $380=$ SEG LIII 716; SEG LVIII 722) [cf. infra no. 14], and a document from Dionysopolis dated by its reference to the eponymous priest of Leto (IGBulg V 5011). A. suggests that the cult of Leto was brought from Lykia to the Milesian sanctuary of Apollon in Didyma in the 6th cent. BCE. According to a Milesian tradition, Didyma is the place where Zeus had sexual intercourse with Leto (Syll. ${ }^{3} 590$

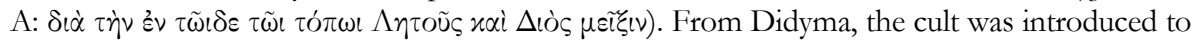
the Milesian colonies along the Black Sea. The cult of Leto is indirectly attested in the Megarian colonies of Byzantion and Chersonesos in Tauris, where there was a month named after her (Latoios). But this seems to be a late development, independent of the Didymean cult and its Lykian origin.

14) A. Avram - I. Bîrzescu - K. Zimmermann, "Die apollinische Trias von Histria", in R. Bol - U. HöCKMANN - P. SchollmeYer (eds), Kult(ur)kontakte. Apollon in Milet/Didyma, Histria, Myus, Naukratis und auf Zypern. Akten der Table Ronde in Mainz vom 11.-12. Mär₹ 2004, Rahden, 2008, p. 107-134 [BE 2009, 357]: The A. collect the evidence for the cult of Apollon, Artemis, and Leto in Histria. Their catalogue of inscriptions consists of dedications to Apollon

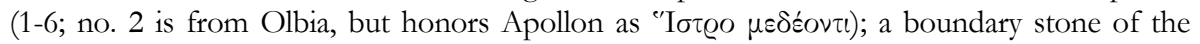
sanctuary of Apollon $\Phi \omega \lambda \varepsilon u \tau \eta \dot{\varrho} \iota s$ (16); a reference to (Apollon) Boreas (17); references to priests of Apollon (7-9) and to Apollon's sanctuary (10-15); dedications to Artemis (18-21); dedications to Leto (22-24); theophoric names (26). The catalogue includes an unpublished dedication to Leto on behalf of a priestess of Artemis Pythie (24) [or possibly by the priestess on behalf of her children] and a dedication to Apollon (a graffito on an Attic vase), known only from a preliminary publication [SEG LV 806(3)]. The cult of this triad must have been introduced to Histria from Miletos. The cult of Apollon dates back to the late Archaic period.

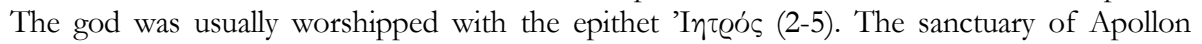
Ietros seems to have been located in the 'temple zone' of the city.

15) P. BAKer - G. ThÉRIAUlt, "Notes sur quelques inscriptions grecques de Lycie (Xanthos, Arykanda et Kadyanda) et deux nouvelles inscriptions xanthiennes”, REG 122 (2009), p. 6384: The A. republish a dedication from Xanthos (TAM II 1, 267, Imperial period; p. 64-66), demonstrating that it cannot be a dedication to Patrioi Theoi. It is, instead, the dedication of a

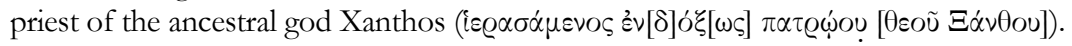

16) M.W. BALDWIN BOwSKY, "An Extra-Mural Sanctuary of Roman Aptera", in Estudios de Epigrafia Griega, p. 315-322: B. republishes a very fragmentary Latin inscription found at Panagia Zerviotissa, in the territory of Aptera (Crete). The text refers to a templum $A[--]$ and mentions some sort of intervention by a man with a Roman name (a magistrate?). This may have been a temple of Asklepios (A[esculapii), but other restorations of a divine name after templum are possible.

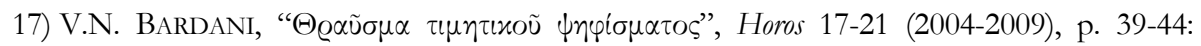
Ed. pr. of a fragmentary honorary decree from Athens (ca 330 BCE). The last lines mention the treasurers of the other gods in connection with the inscribing of the decree (9f.: [ $\tau$ ò

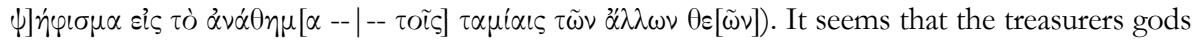

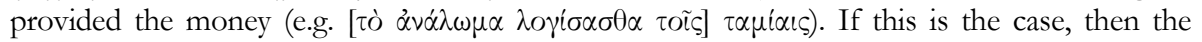
Athenian assembly did not issue the decree. The text shows that in the late 4th cent., the treasurers of the other gods were a distinct body from the treasurers of Athena and had separate financial responsibilities. 


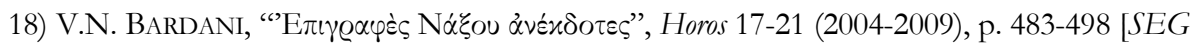
LVIII 895-896, 899]: Ed. pr. of inscriptions from Naxos. Three individuals made a dedication to an unknown deity for themselves and their children (Naxos, late 4th/early 3rd cent., 1: írè $\pi \alpha i \delta \omega \nu \tau \varepsilon$ x $i \alpha i \tau \tilde{\omega} \nu)$. A man made a dedication to Aphrodite (2,1st cent.). A Greek-Phoenician bilingual epitaph mentions a cult association ( $\left.\sigma \cup v \theta \imath \alpha \sigma \tau \tau \alpha_{l}\right)$ in the Greek text $(7,4$ th cent.).

19) A. BARTA, "The Language of Latin Curse Tablets from Pannonia. A New Curse Tablet from Aquincum", ActaAntHung 49 (2009), p. 23-29: Ed. pr. of a lead tablet with a Latin defixio found in a cemetery in Aquincum (late 2nd/early 3rd cent.). The text consists of 12 fragmentary lines. The victims of the curse are several individuals, who are supposed not to act or speak against other individuals. The scribe used the formula ne possit facere/loqui contra and variants (lingua ne possit adversus NN loqui, lingua et nomen ne possit adversus NN facere). The formulaic nature of the text, the low number of mistakes, and the general appearance suggest that the defixio is the work of a professional. Among the ca 40 magical inscriptions from Pannonia, only five are in Latin.

20) A. Bernabé, "Sobre la 'nueva' laminilla órfica de Feras", in Estudios de Epigrafía Griega, p. 323-331 [BE 2010, 375]: B. convincingly defends the Orphic character of the new gold lamella from Pherai (cf. infra no. 58). Orphic features include the material (gold), the use of the tablet in a funerary context, the Thessalian origin, and the deities mentioned in the tablet:

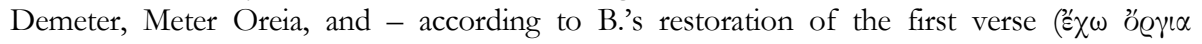
[Bर́xхov]) - Dionysos Bakkchos. With this text, an initiate addresses Persephone in order to obtain the privileged position reserved for the initiates in the underworld.

21) I. BERTI, “The 2006 Campaign at Iasos”, KST 29.1, 2008, p. 295-306 [BE 2011, 539; SEG LVIII 1211]: B. mentions an inscription from Iasos (late 4th cent. BCE) that commemorates the dedication of an andron [for banquets] to Artemia Astias by Eupolemos (a local dynast or an officer of Kassandros). The dedication was made as a tithe (dekate). [On the identity of Eupolemos (son of Simalos, early 3rd cent.), see R. FABIANI, "Eupolemos Potalou o Eupolemos Simalou? Un nuovo documento da Iasos", EA 42 (2009), p. 61-77].

22) M. BlÖMER - E. WINTER, "Das Zentralheiligtum des Iupiter Dolichenus auf dem Dülük Baba Tepesi bei Doliche. Forschungen des Jahres 2007”, KST 30.1, 2009, p. 67-84: The new finds from the sanctuary of Zeus Dolichenos near Doliche include a fragmentary Latin dedication to Iupiter Dolichenus (p. 81).

23) J. BlOK - S.D. LAMBerT, "The Appointment of Priests in Attic gene", ZPE 169 (2009), p. 95-121 [BE 2010, 166]: The A. examine the mechanisms used by Athenian kinship groups (gene) for the appointment of priests. The evidence confirms S. Aleshire's view that a system of allotment was applied. A major piece of evidence is the inscription of the Salaminioi (LSCG Suppl. 19; Agora XIX L4b). Although priests of the gene seem to have been appointed from a more restricted pool of candidates, B.-L. reject Aleshire's assumption that the allotment was $e k$ prokriton, that is, from a pool of pre-elected candidates. The A. provide a list of the known priests of the major gene of the Eteoboutadai (priestess of Athena Polias, priest of Poseidon Erechtheus), Eumolpidai (bierophantes), Kerykes (dadouchos), and Philleidai (priestess of Demeter and Kore in Eleusis).

24) A. Boshnakova, "Hermeneutics of the Archaeological Artifact: Destruction and Reconstruction of the Lost Meaning", in K. BOSHNAKOV (ed.), Jubilaeus VI. Sbornik v pamet na Karel y Hermenegild Śkorpil, Sofia, 2007, p. 51-102 [SEG LVIII 741]: After summarizing the research on the bone plaque from Berezan (ca. 550-525), which refers to Apollon as well as the number seven and its multiples (IGDOP 93; SEG XXXVI 694), B. presents a new interpretation. Observing that the texts on the obverse and the reverse must be interconnected, she 
argues that the text was a prosodion sung during a procession; the sequence of letters on the obverse constitute musical notation - the earliest evidence for a system of vocal and instrumental notation. According to this interpretation, the text consists of an allusion to Apollon's victory over Boreas, a praise, a prayer and blessing, a dedication, and a refrain. The last line, separated from the rest of the text, mentions the god's sanctuary at Didyma. B. assumes that the prosodion was performed by the priest and the worshippers, with the priest calling a number and the people responding by singing the respective line of the song (e.g. $\varepsilon \pi \tau \dot{\alpha}$

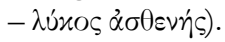

25) L. BRICAUlt, "Fonder un lieu de culte", in C. BONNET - S. RIBICHINI - D. STEUERNAGEL (eds), Religioni in Contatto nel Mediterraneo Antico. Modalità di diffusione e processi di interferenza (Mediterranea, 4), Pisa, 2008, p. 49-64: Adducing primarily the epigraphic evidence concerning the foundation of sanctuaries of the Egyptian gods, B. distinguishes two types of initiatives: those taken by priests or devotees (e.g. in Opous, Eretria, Delos, and Emporion), and those patronized by kings and emperors (especially by the Ptolemies).

26) C.G. Brown, “The Precinct of Zeus and Parmenis' Immortality (CEG 2.693)”, ZPE 170 (2009), p. 21-27: B. discusses a posthumous honorary epigram for a Rhodian woman (late 4th/early 3rd cent.), set up by her parents. According to B.'s reading, the girl claims: "but now the precinct of [- - Zeus holds me, the very one whom Apollo took from the [- - ] fire and

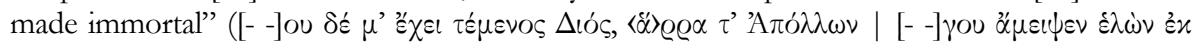
$\pi$ voò $\dot{\alpha} \theta \dot{\alpha} v \alpha \tau O v ;\langle\check{\alpha}\rangle \varrho \propto \alpha=\ddot{\alpha} \nu \varrho \alpha)$. To call the deceased individual "immortal" is unparalleled in

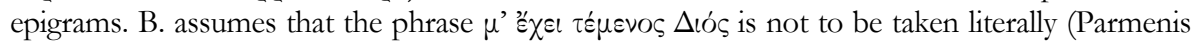
could not have been buried in Zeus' temenos) but as a reference to Zeus' realm, that is, the sky

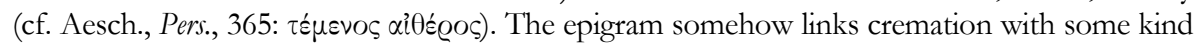
of beatified state (cf. $A P$ VII, 370); it is associated with the well-attested concept of celestial immortality (cf. CEG 10, 535, 593).

27) P. BÜyÜKkolanci - M. Gronewald - H. Engelmann, "Grabepigramm auf den Sklaven Hyllos", ZPE 169 (2009), p. 87-88: The burial ground of the urns of the familia of C. Sextillius Pollio and C. Ofillius Proculus, leading members of the conventus of Roman citizens in Ephesos (late 1st cent. BCE/early 1st cent. CE), were found near the Artemision. An inscribed urn preserves a grave epigram for the slave Hyllos. The text presents Tyche and

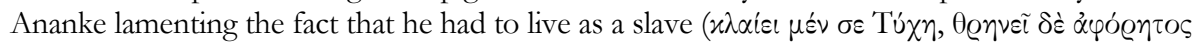

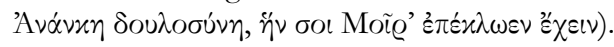

28) K. Buraselis, "Priesthoods for Sale. Comments on Ideological and Financial Aspects of the Sale of Priesthoods in the Greek Cities of the Hellenistic and Roman periods", in A.H. RASMUSSEN - S.W. RASMUSSEN (eds), Religion and Society. Rituals, Resources, and Identity in the Ancient Graeco-Roman World, Rome, 2008, p. 125-131: B. points out that the sale of priesthoods, a common practice from the late 4th cent. onwards, was occasionally criticized. An inscription from Herakleia on Latmos quotes an oracle of Apollon (of Didyma?) according to which the city should not sell the priesthood of Athena Latmia but instead elect a priest every year (SEG LX 956; ca 100-75); this would guarantee that men with moral qualities would be elected from among the entire citizen body. The abandonment of a system of life-long priesthoods in favor of annually elected priests is also attested elsewhere, e.g. in Rhodes (C. BlinKEnBERG, Les pretres de Poseidon Hippios [Copenhagen, 1937]; I.Lindos 647). The sale of priesthoods and the appointment of priests by lot were also criticized by Dionysios of Halikarnassos (Roman Antiquities II, 21, 3). An edict of P. Fabius Persicus (I.Ephesos 18, ca 44 CE) also reveals the negative aspects of the sale of priesthoods for the civic finances. The governor tried to prevent them, not by abolishing this practice but by limiting the financial advantages for the bidders. 
29) F. Cantarelli, "Il mito di Aspális e il santuario di Haghios Gheorghios di Melitea", in F. Cantarelli et al., Acaia Ftiotide I. Indagini geostoriche, storiografiche, topografiche e archeologiche, Soveria Mannelli, 2008, p. 371-434: C. discusses the myth of Aspalis and its connection with the cult of Artemis in Melitaia. The site of Agios Georgios in Melitaia, where at least four cult buildings have been identified, is where, according to the myth, Aspalis hung herself. Philip V probably destroyed this sanctuary in 217 BCE. C. adduces three inscriptions: a dedication to Artemis (SEG XXVII 209), a dedication to Asklepios, and a small fragment (SEG XXVII $210)$, in which C. reads $[\tau] \dot{o} \sum \pi \alpha \lambda i \sigma \iota[o] \nu$, i.e. the shrine of Aspalis.

30) F. CAMiA, "Imperial Priests in Second Century Greece: A Socio-Political Analysis", in Pathways to Power, p. 23-41: C. examines the social position and careers of high priests of the imperial cult in the province of Achaia, Athens, and the Achaian Koinon in the 2nd cent. CE. The holders of this office belonged to the elite and were Roman citizens; although the imperial priesthood enhanced their social standing, only four of the high priests (Atticus, Herodes Atticus, Cn. Cornelius Pulcher, Ti. Claudius Saethidas Caelianus II) entered the equestrian senatorial order (Pulcher also the senate), not because of their tenure in this office but because of their family connections with Roman authorities.

31) A. Chaniotis, "From Woman to Woman. Female Voices and Emotions in Dedications to Goddesses", in Donateur, offrande, déesse, p. 51-68: Focusing on two large groups of inscriptions - the dedications of slaves in the sanctuary of Meter Theon Autochthon in Leukopetra in Macedonia (I.Leukopetra) and the dedications and 'prayers for justice' from the sanctuary of Demeter and Kore in Knidos - C. argues that it is possible to detect differences in the use of emotional language between men and women. In Leukopetra the dedications of men and women do not differ in the perception of the goddess as an angry deity, who punishes sinners or is expected to help those who worship her with piety; however, some of the dedications of women deviate from formulaic expressions to display affection. In the Knidian dedications by women, but also in dedications in other sanctuaries of goddesses, one may observe deviations

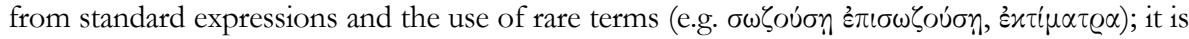
argued that this was a strategy that allowed one dedicant to distinguish herself from others and to express strongly her piety. The dedication of a mother, whose daughter had died, to Demeter after a dream (I.Knidos 131) has an emotional background: the worshipper and goddess shared the same emotional experience, that is, the loss of a child. The convergence of expressions in the Knidian 'prayers for justice' (I.Knidos 147-159) can be explained by the fact that, when the worshippers visited the sanctuary, they interacted during the rituals and displayed their emotions as victims of injustice. This is directly attested in a passage in Polybios (XV, 29, 8-14), in which the historian describes the interaction among angry women and cursing in the Thesmophorion of Alexandria.

32) A. CHANiotis, "The Dynamics of Ritual Norms in Greek Cult", in Norme -- religieuse, p. 91105: A close examination of ritual instructions explicitly mentioned or implied in the decree that concerns the festival of Homonoia in Antioch near Pyramos (LSAM 81) reveals the existence of several layers of norms. Some ritual actions were neither described nor debated but were dictated by custom. Other actions were subject to decisions of the popular assembly or of other secular authorities; they were subject to debate and determined the specific profile of a celebration. Finally, the staging and the 'enlargement' of a ritual were subject to the initiatives of officials, ritual experts, and the community. Numerous cult regulations (e.g. Milet I.3.134; LSAM 16; LSCG 136; LSCG Suppl. 14 = SEG XXI 469 C; I.Magnesia 100) confirm this distinction between a) patria, nomizomena, which did not have recognizable mortal agents; nomoi (decrees and laws), which were subject to codification and modification but hardly allowed initiative or flexibility; and measures for aesthetically more pleasing and more 
impressive performance of rituals (epauxesis). The performance of rituals is not simply a matter of leges sacrae and tradition, but a dynamic phenomenon, involving old, sacred, and invariable traditions, innovations, additions, and variations. Detailed ritual instructions can only be found in certain categories of rituals (magical rituals, rituals of purification), mainly in those that presuppose a certain automatism between ritual action and effect.

33) A. Chaniotis, "Ritual Performances of Divine Justice: The Epigraphy of Confession, Atonement, and Exaltation in Roman Asia Minor", in H.M. COTTON et al. (eds), From Hellenism to Islam: Cultural and Linguistic Change in the Roman Near East, Cambridge, 2009, p. 115-153: The information contained in the so-called confession inscriptions and, more generally, in epigraphic records of divine punishment (dedications, funerary imprecations) permits to a certain extent a reconstruction of the rituals involved in the confession and atonement of sins, and in the exaltation of the gods in Asia Minor. When a person committed, intentionally or not, a crime or violated a norm and thought that the god was inflicting punishment, he went to a local sanctuary and asked for help. By means of oracles, divine messengers or dreams, but also with the active assistance of the priests, the god revealed the cause of his anger and the way by which atonement could be achieved. The sanctuaries were also recipients of accusations submitted to the priests by wronged parties, requesting intervention. Subsequently the priests arbitrated between the parties embroiled in the conflict, administered an oath to the parties, cursed the offenders in order to attract the interest of the gods to the offense, interpreted the signs of the divine will, and consulted those who wished to atone for their misdemeanors. The appeal to divine justice was connected with a variety of rituals: cursing (often involving the submission of written curses, sometimes taking the form of the erection of scepters of the gods who were invoked); praying; taking or annulling oaths (for which sanctuaries sometimes requested fees); the cession of disputed property to the gods; rituals of divination to determine the cause of divine wrath; and rituals of atonement (public confession, transfer of the sin to three or nine animals, purification, acclamations, public praise of the gods, and the erection of a written record). Orality and publicity are important aspects of these rituals, which had a local character (in Asia Minor) but find some parallels in other areas of the Roman world (e.g. in Macedonia). Such similarities sometimes stem from general patterns of human behavior; in some cases they were the result of a transfer of ideas.

34) V. CHANKowski, Athènes et Délos à l'époque classique. Recherches sur l'administration du sanctuaire d'Apollon délien, Paris/Athens, 2008 [BE 2010, 472; SEG LVIII 790]: In her synthetic account of the relations between Athens and Delos, C. discusses in detail the administration of the sanctuary of Apollon in the Classical period. Exploiting the abundant epigraphic sources, and often proposing new restorations of inscriptions, she discusses inter alia the following subjects: the significance of the sanctuary for the Ionians (16-20); the possible existence of an amphiktyony in the Archaic period (20-28); the political exploitation of the sanctuary by the Athenians in the context of the Athenian Alliance (29-49; with discussion of the diffusion of the cult of 'A ó$^{\prime} \lambda \lambda \omega \nu \Delta \dot{\eta} \lambda \iota \mathrm{s}$, the sanctuary's status in the Delian League, the alliance's treasury in Delos, and the administration of the treasury); the purification of the island and the restoration of the $\Delta \eta^{\prime} \lambda \iota \alpha$ (53-77); the festivals of the Classical period, their rituals, and the administrative aspects of the festivals (79-125; the $\theta \varepsilon \omega$ Qi $\alpha$ in honor of Theseus; the Delia; the offerings for the Hyperborean girls); the administration of the sanctuary of Apollon and sacred property (127-146); the Athenian board of $\dot{\alpha} \mu \varphi x \tau \dot{0} 0 v e \varsigma$ and the administration of the sanctuary

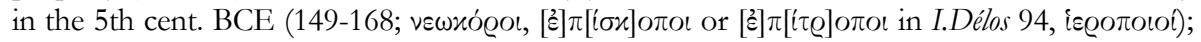
financial management (168-181); the Athenian administration in the 4th cent. (235-273); and the economic activities of the sanctuary (277-376; sacred property, transactions, revenues, taxes, leases, expenses, fiscal management, $\alpha \pi \alpha \varrho \chi \dot{\eta}$, donations). In an appendix, C. presents a concordance of the Athenian and Delian calendars (389). In an epigraphic appendix (397-518), 
C. presents a critical edition and French translation of the main documents discussed in the book, which will be an indispensable reference in the study of the Delian sanctuary.

35) J. Chauvet Garbit, “Le calendrier sacré des Argiens”, REG 122 (2009), p. 201-218: The A. examines several questions concerning the Argive calendar. As regards the system of dating, C.G. argues that the priestess of Hera, who served for life, could not have been an eponymous official - the beginning of her term in office did not coincide with the beginning of the year. Although the lists of priestesses were often used for chronological purposes, Argos must have had an (annual) eponymous magistrate. Making use of the information provided by C.B. KRITZAS on the new tablets from Argos and his study of the month names (see EBGR 2007, 77), C.G. discusses the sequence of months in the Argive year, which started with the summer solstice. The sequence of the first six months is known: Panamos, Agyieos, Karneios, Hermaios, Gamos, Amyklaios (1-6, June/July to November/December). The months Teleos and Arneios should be placed in the spring. The position of Apellaios, Agrianios, Artamitios, and Erithaieos cannot be determined. The names of at least six months are connected with the cult of Apollon (Agyieos, Amyklaios, Apellaios, Arneios, Karneios, and probably Erithaieos). There is only limited overlap between the calendars of Argos and Epidauros.

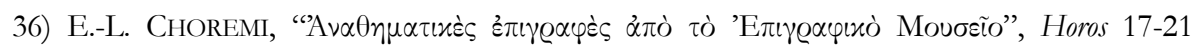
(2004-2009), p. 125-132 [BE 2011, 211]: Ed. pr. of 5 dedications from Athens. A man made a dedication to Asklepios for his daughter ( $I G \mathrm{II}^{2} 4412$ + a new fragment; late 4th cent.). A priest of Isis dedicated a statue of his son to the goddess (early 3rd cent.). The three remaining dedications are very fragmentary.

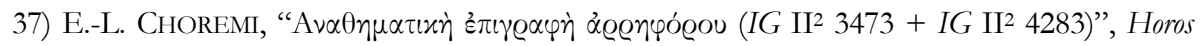
17-21 (2004-2009), p. 133-142 [BE 2010, 212; 2011, 253]: The joining of two fragments from Athens (ca 175-150; IG II $3473+4283)$ permits the restoration of a dedication to Athena. The parents and brothers of Xenostrate dedicated her statue to Athena, when she served as

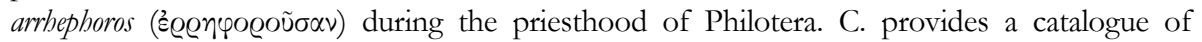
dedicatory inscriptions in honor of arrhephoroi.

38) P. Christodoulou, "Priester der ägyptischen Götter in Makedonien (3. Jh. v. Chr.-3. Jh. n. Chr.)", $M D A I(A) 124$ (2009), p. 325-356: C. collects the evidence for priests of the Egyptian gods in Macedonian cities (Amphipolis, Anthemous, Beroia, Dion, Philippoi, Stobi, Thessalonike, and Terpni/Nigrita). He discusses the diffusion of the cults and the very limited information on the social position and activities of priests (e.g. iteration, wealth).

39) W. Clarysse - M.C.D. Paganini, "Theophoric Names in Graeco-Roman Egypt. The Case of Sarapis", AfP 55 (2009), p. 68-89: Exploiting the onomastic data collected in a database, C.-P. discuss the construction and diffusion of names deriving from Sarapis. Theophoric names deriving from Sarapis were rare in the $3 \mathrm{rd}$ cent. The derived names were Greek, primarily used by Greek families, exactly as Sarapis was perceived as a Greek god. In the Hellenistic period, the more popular names were simple derivations (Sarapion, Sarapias), whereas the full theophoric composita (Sarapodoros, Sarapammon, etc.) first appeared in the Imperial period.

40) K. Clinton, "Donors of Kernoi at the Eleusinian Sanctuary of the Two Goddesses", in Donateur, offrande, déesse, p. 239-246: The kernoi found in the sanctuary of Demeter and Kore in Eleusis are not to be associated with the ritual of kernophoria during the mysteries. The kerchnoi in Eleusinian inventories (I.Eleusis 46 and 52) are not kernoi, but pieces of jewelry. C. argues that the kernoi in Eleusis were used by women who celebrated the Thesmophoria. He infers this from the presence of kernoi in the Thesmophorion of Kythnos, which is closely related to the sanctuary in Eleusis. The Eleusinian sanctuary owned a precinct on Kythnos (I.Eleusis 52 
A.III.26): the rituals transferred from Eleusis to Kythnos were not those of the mysteries, but those of the Thesmophoria.

41) K. Clinton - N. Dimitrova, "A New Edition of IG XII 8, 51", in Meletes Habicht, p. 201-207 [BE 2010, 496]: New edition of a decree of Imbros that calls for a review of the assets of the sanctuary of the Great Gods in Imbros by an Athenian commission (ca. 300-230 BCE; IG XII 8, 51); an inventory containing the results of the review is appended to the

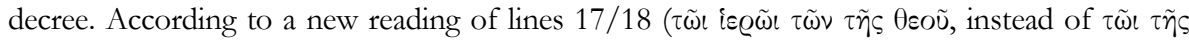
$\theta \varepsilon o \tilde{u})$, this text refers to the sanctuary of the Great Gods, not the sanctuary of a goddess (Athena). The anonymous goddess was one of the Great Gods, having her own property,

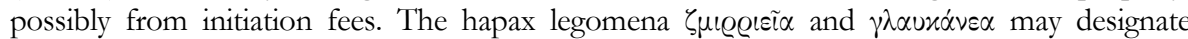
colors of the plants/oils known as myrrh and glaukion.

42) J. CORELL - X. GÓMEZ FonT, "Las inscripciones griegas del País Valenciano (IGPV)", in Estudios de Epigrafia Griega, p. 25-56 [BE 2010, 4]: The A. present 17 Greek inscriptions found in the area of Valencia (no inedita). These texts include two dedications to anonymous deities, one from Alacant $(5=A E 1990,640)$ and the other from Valencia (8). A fragmentary grave epigram from Saguntum (15) refers to the Moirai and possibly to the Muses.

43) T. Corsten, “Kibyra 2005”, AST 24.1, 2007, p. 51-60 [SEG LVIII 1554]: Ed. pr. of a dedication to Zeus Megistos and Trajan found at Mürseller, in the Pisidian-Phrygian borderland (57 no. 4).

44) T. CORSTEN, "Kibyra 2006”, AST 25.1, 2008, p. 125-132 [SEG LVIII 1598]: Ed. pr. of an honorary inscription for a high priest of the imperial cult (Kibyra, 1st cent. CE, p. 128 no. 1). Ed. pr. of a dedication to Herakles (Kibyra, Imperial period, 128f. no. 2).

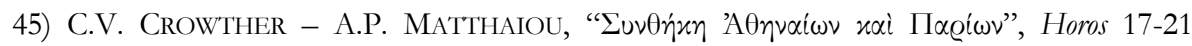
(2004-2009), p. 31-38: The A. present a new critical edition of Staatsverträge II 268 (Athens, 373/2). The inscription contains two decrees. Only the last part of the first decree is preserved (lines 1-14); it refers to the obligation of the Parians, as colonists of Athens, to send to Athens a bull and a panoply during the Panathenaia and a phallos during the Dionysia. The second text is a decree of the synhedrion of the second Athenian Alliance that concerns arbitration, probably during a civil strife in Paros.

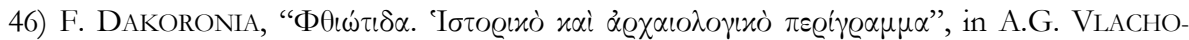

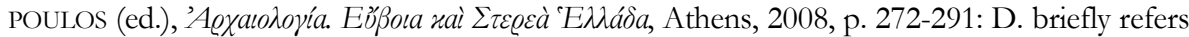
to the excavation of a building at Isomata near Agios Konstantinos (ancient Daphnous; p. 282). According to the finds, it seems to have been an Asklepieion. D. presents a ph. of a vase inscribed with the letters 'A $\sigma x \lambda[\alpha \pi--]$, possibly the god's name [or a theophoric name].

47) D. DANA, “Inscriptions inédites de Macédoine et de Thrace”, ZPE 168 (2009), p. 187-198 [BE 2009, 338]: Ed. pr. of eight dedications of unknown provenance (sold in Germany and the USA); the votive reliefs probably originate in a sanctuary of Zeus and Hera somewhere in Thrace (2nd/3rd cent.). The name of the deities is not preserved intact in any of the inscriptions, but it can be restored as Zeus and Hera Souideptenoi (called xúgı in no. 9). In

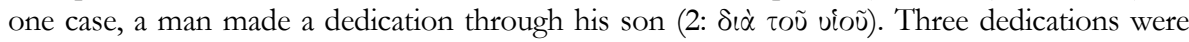

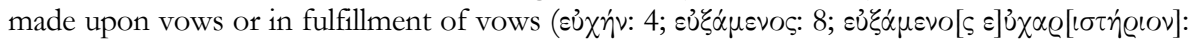
9), another one is designated as a gift (7: $\delta \tilde{\omega} \varrho o v)$. D. also publishes a Latin dedication to Iupiter Optimus Maximus and Iuno Regina by a soldier (10; Moesia inferior or Thrace?).

48) R.W. Daniel - G. Sulimani, “A New Curse Tablet from Jerusalem”, ZPE 171 (2009), p. 123-128 [BE 2010, 605]: Ed. pr. of a rolled lead tablet with a fragmentary defixio found in a bathhouse in Jerusalem (ca. 4th-6th cent.). Only part of the texts on the two sides could be 
read. An anonymous individual curses a series of men, who are identified by their name (in the genitive) and mother's name; one of them was a comes. The names suggest a Christian milieu (Petros, Ioannes, [Anast]asios or [Athan]asios) [but this does not necessarily mean that the

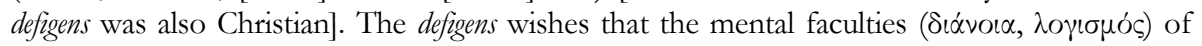
his adversaries are affected [which suggests that it is perhaps a judicial defixio]. One recognizes

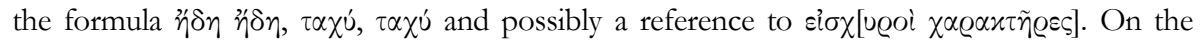
reverse, one encounters magical names (I $\alpha \omega, \Sigma \alpha \beta \alpha \omega^{\prime} \theta$ ), magical signs, and the drawing of a winged being.

49) M.P. DE Hoz, “The Aretalogical Character of the Maionian 'Confession' Inscriptions”, in Estudios de Epigrafia Griega, p. 357-367: Presenting several examples of 'confession inscriptions' from Maionia in Lydia (e.g. BIWK 3, 59, 65, 79; SEG LVII 1158), the A. rightly points out that

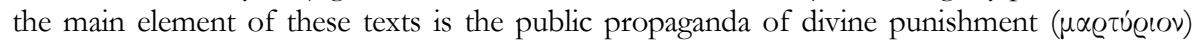
and, through this, the strengthening of the social and economic influence of sanctuaries. Such a manifestation of divine power, the citation of acclamations, and the element of praise ( $\left.\Sigma \dot{\lambda} \lambda \circ \gamma^{\varepsilon} \omega\right)$ liken these texts to aretalogies. But while aretalogies and narratives of miracles focus on the positive aspects of gods (Asklepios, Isis, Serapis), these inscriptions highlight the power of god to detect and to punish sins.

50) G. Deligiannakis, “Christian Attitudes Towards Pagan Statuary", Byzantion 78 (2008), p. 142-157 [SEG LVIII 822-823]: D. discusses two Late Antique epigrams from Rhodes (4th/5th cent.), one of them an ineditum. They commemorate the gifts of Anastasios, a Christian (cf. the name) benefactor (or governor). Both epigrams were inscribed on the bases of pagan images: Herakles and his labors and Maron: 1) "Herakles, blood of Zeus ( $\alpha \tilde{i} \mu \alpha \Delta$ iós), slaughterer of animals, not only were you born in previous times to fend off evil ( $\dot{\alpha} \lambda \varepsilon \xi i \varkappa \alpha \varkappa \circ \varsigma)$; but our age too gave birth to Herakles, the noble Anastasios, the famous founder of the Rhodians, who dedicated you here, together with your remarkable feasts." 2) "Here the drunkard and slumbering Maron was dedicated by Anastasios of high repute; fresh water flows from the wine skin under his palm." These inscriptions provide important evidence for the use of pagan, mythological imagery in a Christian setting (cf. I.Kourion 204, in which Eustolios, a Christian benefactor, is compared to Apollon). A cross was engraved on the first base after its erection, whereas on the second, a cross seems to be contemporary with the inscription. In the first case, the cross was probably added by Christians offended by the image of the pagan hero (cf. SEG LII 1036) - despite the fact that the Christians could regard Herakles as a symbol of virtue. In the second case, the cross was intended to protect, seal, and decorate, rather than to

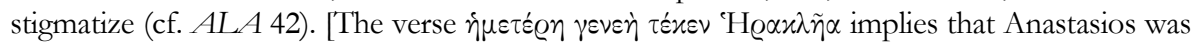
called "(new) Herakles" in acclamations, such as the ones recorded in $A L A$ 83. In the two epigrams from Rhodes and Kourion, in which a pagan god is compared with a Christian benefactor (Herakles-Anastasios, Eustolios-Apollon), this comparison was legitimated in a Christian context through the use of words that clearly separated the pagan past from the

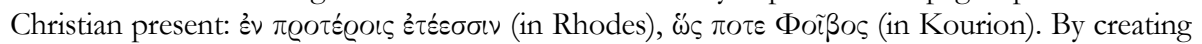
a distinct temporal setting for the mythological, pagan past, its protagonists (Herakles, Phoibos) become irrelevant for the Christian present and, consequently, are no longer a threat. In the case of Maron, we note the humorous nature of the epigram; in the Christian context, Maron, so closely associated in mythology with excellent wine, is not pouring wine but water.]

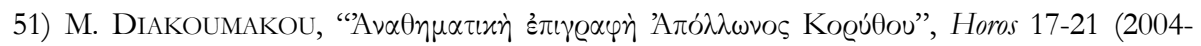
2009), p. 311-315 [BE 2011, 280]: D. republishes a dedication to Apollon Korythos

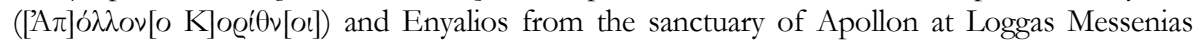
(early 5th cent.). The joint dedication to Apollon and Enyalios reveals the god's warlike 
character. Yet, the form of the epithet (Kó@ı $\theta$ vos) casts some doubt on its presumed derivation from xógus (helmet).

52) S.. DiLEK Ful, “A Dedication to Isis and Sarapis”, EA 42 (2009), p. 101 [BE 2011, 490]: Ed. pr. of a dedication to Isis and Sarapis by a Roman citizen in fulfillment of a vow (Parion, 1st cent. CE?). This is the first epigraphic attestation of the cult of the Egyptian gods in Parion.

53) B. Dreyer - H. Engelmann, "Neue Dokumente zum Kult des Ares in Metropolis", ZPE 168 (2009), p. 161-176: Ed. pr. of 22 inscriptions inscribed on columns of the sanctuary of Ares in Metropolis (Ionia); Ares was regarded as the protector of the city. The texts record the names of the cult personnel in the service of Ares in a given year: the priest, the priestess, two to nine diakonoi, and an odrogos. One may often observe family relations among the cult personnel. For instance, in no. 1 two diakonoi were brothers, in no. 2 the priest and four diakonoi were related; in no. 4 Menophantos was priest, his daughter Moscha priestess, and his brother one of the diakonoi; in no. 5 the priest's mother served as priestess, and her daughter as diakonos; in no. 6 the diakonoi were two pairs of brothers; in no. 19 the mother of the priest was priestess, his sister and two brothers served as diakonoi; in no. 20 the priest mentions the fact that his grandfather and great grandfather had served in this office; his mother served as priestess, his brother and sister were among the diakonoi. From this, one may infer that the priests recruited the personnel for their year in office from their circle of family members and friends. The fact that a woman served as priestess suggests that Ares had a female companion in his cult at an early phase. The pairs of priests include a mother and her son $(5,16,19,20$, $22)$, a father and his daughter $(4,8,12)$, a brother and his sister $(13,15,17-18)$, and a nephew and his aunt (22), but never a husband and his wife. Iteration in office is often attested. In one

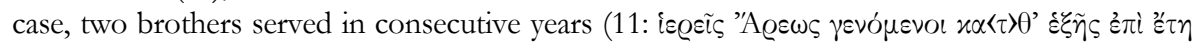
$\delta \cup ́ \omega)$; the priestess was the same in both years. A brother and a sister served together for two years (17-18). A woman served as priestess twice, the second time together with her son (16), and another woman together with two different men of the same family (10 and 14). [The latter case shows that the women, whose relation to the priest is not indicated, must be relatives, but that they cannot be their wives: Stratoneike, daughter of Agathokles, served with two different men $(10,14)$ who belonged to the same family, Pherekles, son of Skymnion, and Diogenes Pherekles, son of Pherekles]. In some cases the diakonoi included women as well (5, 7, 11, 13, 16, 19-21). The odrogos seems to have been a specialized member of the cult personnel, assisting the priest and priestess in their ritual duties, comparable to the office of the bierophantes in Ephesos (cf. I.Ephesos 10 lines 17-22). The term is not Greek and of unknown origin, related to an early phase of the cult. This office seems to have been the privilege of certain families, responsible for the transmission of cultic traditions. A man, his brother, and his son served as odrogoi in eight different years; another man and his son served in three other years. In the Imperial period, this service was undertaken also by slaves (17-21). [On the cult of Ares in Metropolis see also B. DREYER, "Le culte civique d'Arès et le panthéon de Métropolis (Ionie)", ZPE 110 (2008), p. 403-416.]

54) C. DuRvye, "Évolution fonctionnelle d'une divinité à l'échelle locale: les offrandes à l'Aphrodite de Stèsileôs à Délos", in Donateur, offrande, déesse, p. 149-167: Studying the inscriptions (inventories) and the archaeological evidence, D. observes a change in the dedicatory practices in the sanctuary of Aphrodite, which was founded by Stesileos in Delos in the late 4th cent. In the earlier phases, i.e. upon the sanctuary's foundation and in the period of Delian independence, the dedications were of a durable character and necessary to the operation of the sanctuary: Aphrodite's cult statue and other statues, a temple, funds for festivals, statues, a vase, a marble table, et sim. Most of these dedications were made by the founder himself, Stesileos, and by his daughter, Echenike. The other dedicants were mostly 
men of prominence in public life. A change occurred during the period of Athenian occupation, after the expulsion of the Delian elite in the 2nd cent. BCE. Thereafter, the inventories of 156 and 146 BCE include jewelry, small figurines, and, above all, articles of clothing. These dedications and the archaeological evidence for the enlargement of the sanctuary indicate the popularity of the cult among the population as well as the great significance of dedications of personal devotion. The dedicants of this period include three priestesses and representatives of the new immigrants (one Roman, one Athenian). In this period, Aphrodite seems to have been primarily worshipped as a patron of marriage, whereas in the earlier periods, she probably was perceived as a patron of magistrates.

55) R.M. ERrington, “The Dionysian Technitai in Athens”, in Meletes Habicht, p. 209-213 [BE 2010, 200]: According to a Delphic inscription (CID IV 12), the Dionysiac artists had received

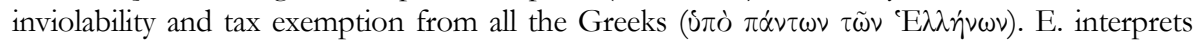
this as a reference to the award of these privileges by the Hellenic League of Demetrios Poliorketes during the celebration of the Pythia in Athens in 290 BCE.

56) S. FolLET, "Un document d'époque sévérienne (IG II² 1118+1104 complétés)", Meletes Habicht, p. 155-163: F. republishes a decree of the Areios Pagos (Athens, early 3rd cent. CE), consisting of several fragments (previously published as IG II 1118 and 1104). The fragmentary status of the inscription does not permit any certainty about the content (abuses concerning the price of grain and order?); but it seems that the pyrphoros Alkamenes played an important role.

57) S. Follet - D. Peppas Delmousou, "Inscriptions du Musée épigraphique d'Athènes", BCH 133 (2009), p. 301-470: The A. present numerous inscriptions from Athens (Imperial period), partly inedita, partly texts resulting from the reassembly of fragments. The most interesting text commemorates the dedication of statues of the Nymphs in the precinct of

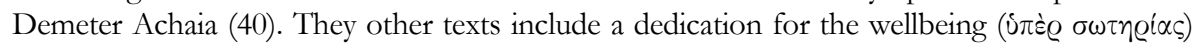
of Augustus (4); a dedication to Hadrianos Olympios Soter and Ktistes (5); two small fragments of dedications of honorific statues (13-14); a fragment mentioning a priestess of Athena $\left(15=I G I^{2}\right.$ 3951). A fragment names (as dedicant) Licinius Firmus, agonothetes of the Great Panathenaia, priest for life, and pyrphoros ex Akropoleos (25; cf. IG II ${ }^{2} 3563$ ). A zakoros was honored for his piety (33). A priestess of Kourotrophos (Ge or Demeter?) was honored by her sons with a statue (39, ca 1 st cent. CE.).

58) W.D. Furley, “'Admit Me to the Company of Initiates'. Suggestions on the Text of the Recently (Re-)Discovered Gold Funerary Lamella from Pherai”, ZPE 170 (2009), p. 31-34 [BE 2010, 375]: Critically discussing the restorations proposed for the new Orphic lamella from

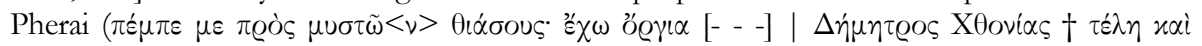

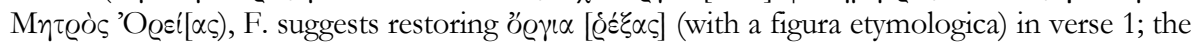
combination of $\varepsilon^{\prime} \chi \omega$ with an aorist active participle is very common in poetry. For verse $2, \mathrm{~F}$. supports the emendation $\tau \varepsilon \lambda\langle\varepsilon \tau \tilde{\eta}$, which presupposes a combined cult of Demeter Chthonia and Meter Oreia. Such a link may be provided by the Epidaurian hymn for the Mother of the Gods [cf. infra no. 164], who is associated both with Demeter and with the Mountain Mother.

59) M. García Teijeiro, "Sobre las piedras-talismán del instrumento mágico de Pérgamo”, in Estudios de Epigrafia Griega, p. 389-396: G. detects parallels between the magical words in the famous 'divinatory kit from Pergamon' and magical papyri [for two very detailed studies (unknown to G.) see EBGR 2004, 97 and 183].

60) S. GiannobiLe, "Una nuova defixio da Cipro", ZPE 171 (2009), p. 129-130 [BE 2010, 57]: Ed. pr. of a fragmentary lead tablet (Cyprus, unknown provenance, 3rd cent. CE). As can be inferred from parallels, the defigens invokes gods against adversaries in a lawsuit. Only a few 


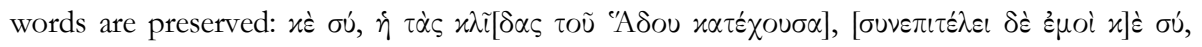

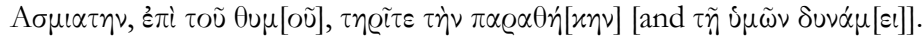

61) F. GRAF, "Zeus and his parhedroi in Halikarnassos. A Study of Religion and Inscriptions", in Estudios de Epigrafía Griega, p. 333-348: G. recognizes allusions to Zeus' cult in the long verse inscription from Halikarnassos, which praises the city and narrates local myths (SEG XLVIII 1330). The text presents a local version of Zeus' infancy: "Halikarnassos brought forth a grand crop of Earth-born men, assistants of mighty Zeus of the Heights. It was they who first placed Zeus, newborn, the son of Rhea, under a hollowed crest, so that he was hidden, and who fostered him in the innermost recesses of Earth, when Kronos crooked of counsel was thwarted from placing him far down in his throat. Father Zeus made the sons of Earth famous ritual attendants who guard the secret dwelling. And the reward they got for their toil was not

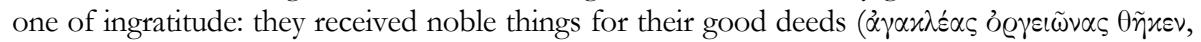

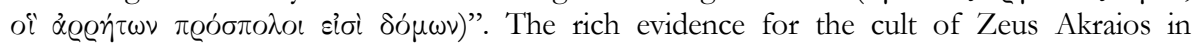
Halikarnassos and its vicinity (sacrifice of a goat, which offers itself for the sacrifice, existence of an andron for ritual banquets, possibly a sacred grove, a rain ritual), finds some parallels in the cult of Zeus Akraios in Magnesia in Thessaly. The text does not reveal the identity of Zeus' attendants, but it is more likely that they were the Kouretes rather than the Korybantes. Hellenistic epigraphic evidence from Southwest Asia Minor suggests that a local cult group was understood as Zeus and the Kouretes. But since a cult of the Korybantes is attested in Halikarnassos (and Miletos), it is certainty not possible in this case. Zeus and these attendants must have been worshipped with mystical rites and banquets by a group of leading citizens.

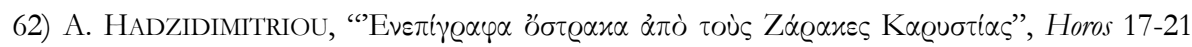
(2004-2009), p. 521-540 [BE 2011, 321; SEG LVIII 963]: Ed. pr. of 20 graffiti on vases found in the sanctuary of Apollon Delios in Zarax/Euboia (cf. SEG XLIX 1205; LVI 1041-1042).

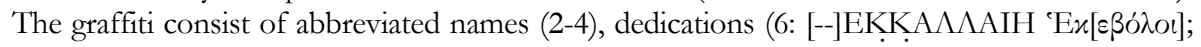
8: [-]EKH[--]; 9: $\Lambda$

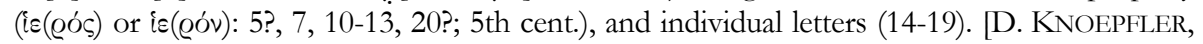
$B E 2011,321$, expresses doubts on the restoration of the epithet $\varepsilon x \eta^{\prime} \beta 0 \lambda o s$ in nos. 6 and 8.]

63) K. Hallof - S. Prignitz, "Zwei Priester namens Euphrantidas in Lindos", AfP 55 (2009), p. 289-294. H.-P. show that the fragmentary inscriptions I.Lindos 106 and IG XII 1, 822 belong together, honoring Euphrantidas, son of Ketidas, priest of Athena Lindia and of Zeus Polieus (266 or ca 237-217). This Euphrantidas is, therefore, a different man than Euphrantidas, son of Charidamos, who served in the same office (ca 192-171 rather than ca 237-217).

64) K. Hallof - S. Prignitz, “IG XII 1, 824”, ZPE 170 (2009), p. 81-86 [BE 2010, 476]: Using a squeeze preserved in the $I G$ archive in Berlin, H.-P. present a new edition of a dedication from Lindos (IG XII 1, 824). It is a dedication made to Athena Lindia and Zeus Polieus by Philodamos, a former priest of Athena Lindia, Zeus Polieus, Artemis in Kekoia, Helios in the asty (i.e. in Rhodes, probably ca 189-182 BCE), and the Muses. Philodamos is known from another dedication (I.Lindos 194), from the list of the priests of Athena Lindia (for the year $169 \mathrm{BCE}$ ), and from a list of magistrates as an athlothetes (IG XII 1, 819 line 15). The chronology suggested by H.-P. shows that Philodamos served first as priest of Helios and later as priest of Athena Lindia; this is one of several exceptions to the usual Rhodian cursus honorum.

65) J. HAMmERSTAEDT - M.F. SMITH, "Diogenes of Oionanda: The Discoveries of 2009 (NF 167-181)", EA 42 (2009), p. 1-38: The A. present a substantial number of fragments of the philosophical inscription of Diogenes of Oionanda. A new fragment from the Physics (NF 167 III), preceding fr. NF $126 \mathrm{I} / \mathrm{II}$, allows a restoration of a section in which Diogenes rejects the idea that the fear of the gods prevents mortals from committing acts of injustice: "For some 
say that this doctrine does not benefit our life, for human beings even in the present situation act wrongly so far as they possibly can; that if, however, they are also released from their fears derived from the gods, they will act completely wrongly, and as consequence the whole [of life] will be confounded. However, [people of such behavior] are even now those who do not fear the gods ([let] this [be] agreed; for if they feared the gods, they would not do wrong). But, as for the others, I declare that those who grasp arguments based on nature are not righteous on account of the gods, but on account of their having a correct view of the nature of desires and pains and death (for, indeed, invariably and without exception, human beings do wrong either on account of fear or on account of pleasures), and ordinary people, on the other hand, are righteous, insofar as they are righteous on account of the laws and the penalties imposed by the laws hanging over them." (5-12). A fragment of the Ethics (NF 168) refers to the soul (the immortality of the soul?), but a restoration is not possible.

66) C. Hasenohr, “Mercure à Délos”, in A. BOuET (ed.), D'Orient et d'Occident. Mélanges offerts à Pierre Aupert, Bordeaux, 2008, p. 27-38 [SEG LVIII 794]: H. studies the relationship between Hermes and Mercurius on Delos, collecting the epigraphic evidence for their public cult (by the Italici) and the cult in private contexts (I.Délos 1711-1714, 1731-1734, 1737, 1741, 1744, $1749,1750)$ and the iconographic evidence for the festival of the Compitalia [see EBGR 2003, 66]. H. discusses in detail the building inscription I.Délos 1741 concerning the construction of a sanctuary of Hermes/Mercurius and Maia, which consisted of a temple, an altar, an offering box, and possibly a peribolos with $\pi \alpha[\varrho \alpha \sigma \tau \alpha \dot{\delta} \varepsilon \varsigma]$ (p. 27-31). The epigraphic and iconographic evidence suggests that the Italici publicly worshipped the Roman Mercurius in close

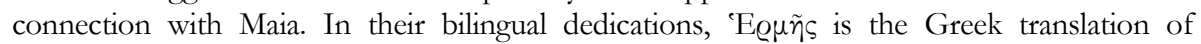
Mercurius. In private contexts, Maia is not mentioned, and Mercurius is conflated with Hermes. As regards the associations of merchants, it is not clear whether their patron was the Roman Mercurius or the Greek Hermes.

67) M. Holzner - E. WeBer, “Annona epigraphica Austriaca 2007”, Tyche 23 (2008), p. 181225: The A. summarize epigraphic finds from Austria. They include a gem with an invocation of Zeus Sarapis from Carnuntum (G. DeMBSKI, "Die antiken Gemmen und Kameen aus Carnuntum", in F. Humer, ed., Archäologischer Park Carnuntum. Neue Forschungen 1, Vienna,

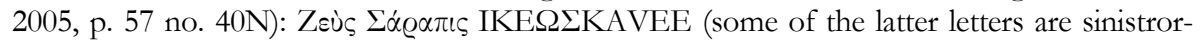

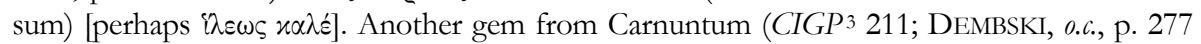

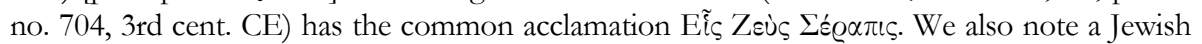
amulet from Habturn (p. 197f. no. 140; originally published by A. LANGE - H. TAEUBER, "Ein jüdisches Amulett", in J. TIEFEnBACH, ed., Die Bernsteinstraße. Evolution einer Handelsroute, Eisenstadt, 2008, p. 177-179; F. DAIM - N. Doneus - H. TAEubER, "Das jüdische Amulett von Halbturn. Ein Zeugnis früher jüdischer Präsenz”, ibid., p. 180-182). The Hebrew text written with Greek letters is a slightly modified quotation of 5 Moses 6.4.

68) P.S. Horky, "The Imprint of the Soul: Psychosomatic Affection in Plato, Gorgias and the 'Orphic' Gold Tablets”, Mouseion series VIII 6 (2006), p. 371-386: According to Gorgias, Helen 13f., the logos creates an imprint or stamp on the soul. In Plato, Gorgias (524d 2 -525a 7), when the soul, after its separation from the body, approaches to receive its judgment, it makes a display of its natural affections and those it has received from its worldly experience. $\mathrm{H}$. recognizes motifs of Gorgianic psychosomatics and Platonic metaphysics in references to judgment and suffering in the Dionysiac-Orphic texts, especially II B2 from Thurioi (OGF 492 F). According to his tentative reading, the logoi left a material imprint on the initiate's soul, effecting joy as soon as he reached the final judgment. 
69) S.C. Humphreys, "Ephêboi at Oropos", Horos 17-21 (2004-2009), p. 83-90: H. reexamines an honorary inscription for a strategos and a kosmetes, and a list of Athenian ephebes of the Leontis from the sanctuary of Amphiaraos in Oropos (I.Oropos 353, c. 330-322). She rejects the traditional identification of the kosmetes Philokles with a general in charge of Mounychia in 325/4 (Deinarchos III.15). The text is probably earlier. A possible date is $329 \mathrm{BCE}$, the year in which the Athenian Great Amphiaraia were celebrated for the first time. This inscription belongs to the group of 'end-of-year dedications' of ephebes, which were set up either in the squadron's tribal sanctuary or in the fort where they were stationed. H. suspects that the Leontis squadron was stationed in Rhamnous, made a visit to Oropos (for the Amphiaraia?), and held its passing-out ceremony there. In an appendix (p. 87-90), H. provides a list of ephebic dedications (end-of-year dedications from a tribal sanctuaries and garrison forts, victory dedications).

70) A. INGLESE, Thera arcaica. Le iscrizioni rupestri dell'agora degli dei, Tivoli, 2008 [SEG LVIII 829]: I. republishes 95 rock-cut inscriptions from the so-called agora of the gods in Thera, some of which consists of gods' names $(1-28,92$ ?, 95). The texts refer to the following cults (p. 83-98): Aphrodite, Apollon (Agyieus, Karneios, Lykeios), Athena, Boreas/Boreaios, the

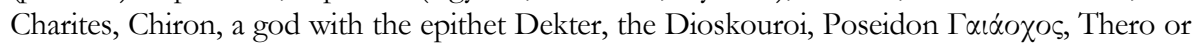
Theros, and Zeús (Hikesios and possibly Pelorios and Polieus). Readings and interpretations

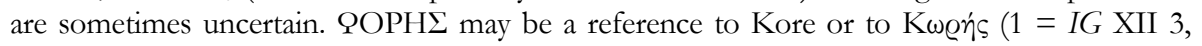

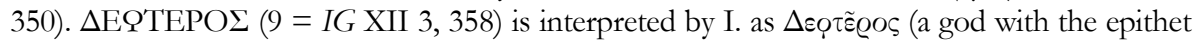

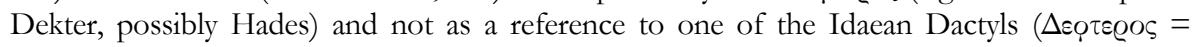

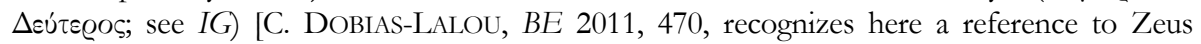
Hikesios (cf. IG XII 3, 402-403), who accepts the suppliants]. The inscription $\Lambda$ ox $\alpha \dot{i} \alpha \Delta \alpha i \alpha$ $(12=I G$ XII.3.361) is usually understood as a reference to two separate goddesses; a cult of Damia and Auxesia is attested in Aigina, and Lochaia may correspond to Auxesia. I. does not exclude the possibility that $\Lambda$ ox $\alpha i \alpha$ is an epithet of Damia. A reference to the Erinyes $(18=I G$

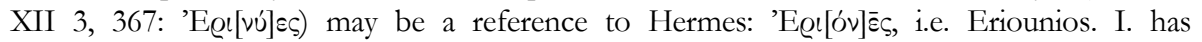
discovered a few unpublished graffiti. One of them is an invocation of Zeus (95, 7th cent.), a

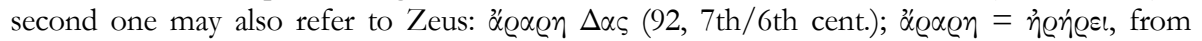

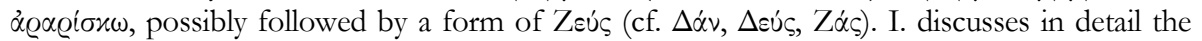
importance of the cult of Apollon Karneios (p. 366-394) and the complex nature of these graffiti, as evidence of devotion and self-representation (p. 403: "l'agora degli dei sembrebbe, così configurarsi, in un orizzonte de inizi VII sec., come uno spazio di ritualità communitaria che si realizza attraverso un sistema di performances abituali segnalate dalla scrittura, e che trovano espressione, in forme e contesti differenti, e cioè nell'ambito di manifestazioni di devozione, nella sfera agonale, nell'autorappresentazione, nella comunicazione amorosa o negli aspetti iniziatici, tutti tenuti insieme però da un sistema di condivisione socio-culturale, che trovò espressione anche nel complesso delle forme di ritualità relative ad Apollo nella sua particolare natura di Carneo").

71) B. IPLIKÇIOĞLU, "Dogu Likya'da epigrafya arastirmarlari 2006”, AST 25.1, 2008, p. 355364 [SEG LVIII 1588]: I. mentions an inscribed funerary altar from Arykanda (Imperial period) [the text is read by T. Corsten in SEG. The altar was erected by two women for Mouse, called an $\dot{\eta} \varrho \omega^{i} \zeta$, according to her will. C. suspects that the last phrase on the stone, xai $\tau \dot{\alpha} \varepsilon \dot{\varepsilon} \pi \gamma \varepsilon \nu \mid \nu \eta \theta \dot{\varepsilon} v \tau \alpha \mu \varepsilon v \varepsilon \tilde{\imath} \tau \tilde{\varphi} \tau \dot{\alpha} \varphi \varphi$, may be a later addition. The names of the dedicants (Gnome, Syntrophia) indicate slave status. They may have been freed by Mouse with her testament, and obliged to perform the funerary rites. The last phrase may be a reference to the fact that their descendants ( $\tau \dot{\alpha}$ ż $\pi \imath \varepsilon \varepsilon v \eta \eta \dot{\varepsilon} v \tau \alpha$ ) will have the same obligation ("the children who will be born in addition to them will remain obliged to the grave".] 
72) B. IPLIKÇIOĞLU, "Ein neues hellenistisches Ehrendekret aus Aryknada (Lykien)", $A A W W$ 143.2 (2008), p. 117-126 [BE 2009, 481; SEG LVIII 1586]: Ed. pr. of an honorary decree for Ermananis for his services in the performance of sacrifices (Arykanda, 2nd/1st cent.). His

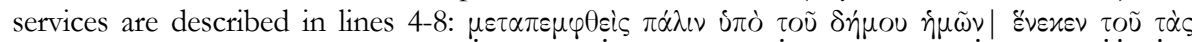

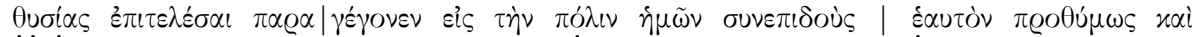

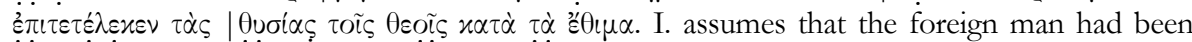

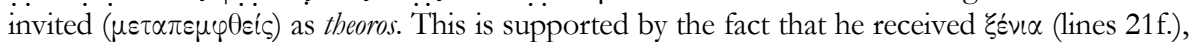
a common honor awarded to theoroi. [This interpretation is possible but raises several questions. First, the text explicitly states that Arykanda invited him; a city usually invites another city to dispatch theoroi to a festival; it does not invite a particular individual as theoros and does not have the right to determine which citizen of a foreign city will serve in this capacity. Second, the verb ध $\pi \iota \tau \varepsilon \lambda \varepsilon \tilde{\nu}$ implies that Ermananis performed the sacrifices himself. Thus, he provided this service on a regular basis $(\mu \varepsilon \tau \alpha \pi \varepsilon \mu \varphi \theta \varepsilon i \varsigma \pi a ́ \lambda l v)$. All this suggests to me that he was not invited as theoros of a foreign city but as a 'ritual expert', possibly as a hereditary priest responsible for the performance of a sacrifice.]

73) A. JacQuemin, "L'inverse est-il-vrai ? Peut-on penser la donatrice dans un sanctuaire masculin?", in Donateur, offrande, déesse, p. 69-79: J. addresses the methodological problems connected with the presence of female dedicants in sanctuaries of male gods. Can one identify female dedicants when the name is not preserved? Which factors determined the choice of gods - healing gods and mystery cults being particular cases? Are there types of 'female' dedications (e.g. clothes)? [For methodological reflections on the use of epigraphic and archaeological sources in the study of dedications, see also V. PiRENNE-Delforge, "La poikilia des offrandes et le souci de les comprendre", ibid., p. 319-333.]

74) A. JACQUEmIN, "La participation in absentia au sacrifice", in Sacrifice antique, p. 225-234: J. discusses cases in which a benefactor receives the exceptional honors of being given a

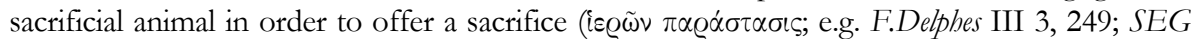
XLIX $1161=I G$ XII 6, 1224), or having a sacrifice offered in absentia to a divinity by a

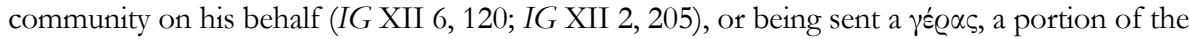
sacrificial meat (IG V 2, 265-266; XI 4, 1038; J. KEIL - A. VON PREMERSTEIN, Bericht über eine Reise in Lydien und der südlichen Aiolis, Vienna, 1910, p. 84f.; I.Amyzon 3, 15, 38; I.Sardes 1; F.Delphes III 3, 145; SEG XXXIII 139). It is not clear what was sent to the honored individual: a portion of meat or money (the money received from selling the honorand's portion)?

75) M. KANTIRÉA, "Une famille sacerdotale du culte impérial de Sicyone (Syll.3 846 et IG IV 399)", in Pathways to Power, p. 15-22: K. discusses evidence for a family of imperial priests from Sikyon. She identifies the high priestess of the empress ( $\varrho \varrho \chi \varepsilon \varepsilon \varrho \varepsilon \alpha \sum \varepsilon \beta \alpha \sigma \tau \tilde{\eta} \varsigma$ ) who was honored in an inscription found in Corinth (IG IV 399) as Polykrateia (cf. IG IV 435), the mother of Tib. Claudius Polykrates of Sikyon. Polykrates, to whom Plutarch dedicated the Life of Aratos, was a descendant of Aratos; he served as high priest for life. The honorary inscription also mentioned Polykrateia's granddaughter, Claudia (Polykrateia) Nausika, high priestess of the empress for life. Polykrateia's son and granddaughter are also mentioned in an honorary inscription from Delphi, with which the Amphictyony and the Achaian Koinon honored Nausika, high priestess of the Koinon (Syll.3 846). In the Delphic inscription Polykrates' office

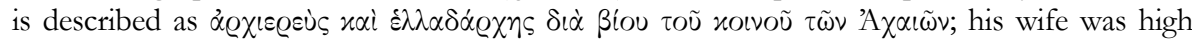
priestess of the Koinon. Based on these inscriptions and the fact that the shrine for the imperial cult in Sikyon was near the heroon of Aratos (Paus., II, 8, 1), K. reconstructs the history of the imperial cult in Sikyon and the Achaian Koinon as follows: The cult of the emperor was established by Pythokles, Polykrateias' father, during Nero's visit (67 CE), when the emperor was associated with Zeus Eleutherios; Polykrateia became priestess of Messalina; the location 
of the shrine near the beroon of Aratos and the fact that one of the two festivals for Aratos was dedicated to Zeus Soter imply that the imperial cult was connected with the heroic cult of

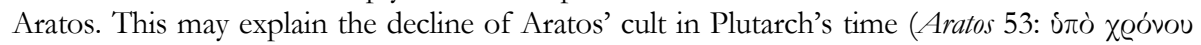

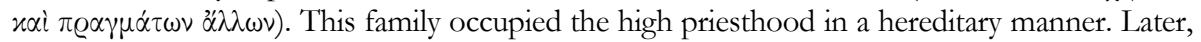
Polykrates became high priest of the Koinon. The association of a beroon with the imperial cult is perhaps paralleled by the 'Treasure of Minyas' in Orchomenos, where a fragmentary inscription mentioning an emperor was discovered (SEG XXX 453).

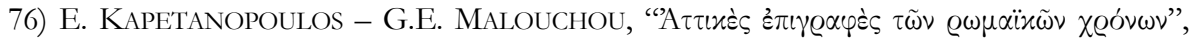
Horos 17-21 (2004-2009), p. 163-195 [BE 2011, 263]: Ed. pr of three lists of ephebes from Athens (150-210 CE; 1 + IG II 2065 , 3-4); another ephebic list (2 = IG $\left.I^{2} 2211\right)$ is presented in an improved edition. These lists mention, among the officials, the agonothetai of the Germanikia (1), the Hadrianeia (1, 3, 4), the Antinoeia in Eleusis (3, 4), and the Antoneia for Divus Marcus (3). The A. also present the ed. pr. of an honorary inscription for a priestess of Demeter and Kore (5), already known from I.Eleusis 377. She is honored for her piety toward the goddesses.

77) L. KARLSON, “Labraunda 2007”, KST 30.1, 2009, p. 107-118: K. reports the discovery of a dedication to Zeus Labraundos in fulfilment of a vow near the South Thermae in Labraunda (Hellenistic).

78) G. KARAUĞUZ, "Karadeniz Ereglisi ve Amasra Arkeoloji Müzelerinde bulunan bazı eserler hakkinda", AST 25.1, 2008, p. 55-64 [SEG LVIII 1465]: K. mentions the discovery of a fragment of a statue group representing Herakles killing a boar (Herakleia Pontica, Imperial period, p. 58). [The inscription on the base was read by T. Corsten in SEG: It is a dedication of a statue of Herakles Alexikakos by a man upon divine command: $x \alpha \tau \dot{\alpha} \sigma u v \tau \alpha \gamma \eta \dot{\nu}$.]

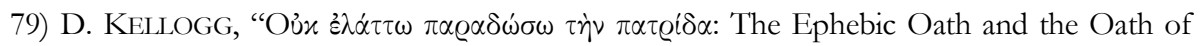
Plataia in Fourth-Century Athens", Mouseion series III 8 (2008), p. 355-376: K. reprints the texts on the stele from Acharnai with the so-called Oath of Plataia [cf. EBGR 2008, 95], summarizes the arguments against the authenticity of the 'Oath of Plataia' (p. 358-362), and, by adducing contemporary political orations, places the inscription in the historical context of mid-fourth century Athens. The inscribed texts recalled Athenian resistance to the Persians and intended to inspire similar achievements on the part of young men during the period of the Athenian conflict with Philip II of Macedon.

80) I. KIZGUT et al., "In Önü yüzey araştırmaları 2005”, AST 24.1, 2007, p. 99-106: Ed. pr. of a votive stele bearing a relief representation of a 'rider god' (area of Termessos, Imperial period). The stele was dedicated to Herakles in fulfilment of a vow.

81) D. KNOEPFLER, "Louis Robert en sa forge: ébauche d'un mémoire resté inédit sur l'histoire controversée de deux concours grecs, les Trophônia et les Basileia à Lébadée", CRAI 2008 [2010], p. 1421-1462 [BE 2011, 298; SEG LVIII 439]: K. summarizes the content of unpublished notes by L. Robert treating the history of the festivals of the Basileia and Trophonia of Lebadeia. Robert had reviewed the epigraphic evidence (mostly agonistic inscriptions) concerning these two festivals, without, however, offering a solution to the problem of the relation between them, their history, their possible co-existence, and the progressive replacement of the one by the other. Updating the information concerning the chronology of the relevant inscriptions and furnishing evidence not considered by L. Robert, $\mathrm{K}$. reconstructs the history of the two festivals as follows: The Basileia were established during the Theban hegemony (after 371 BCE); they were organized by the Boiotian Koinon after 287 BCE and acquired the status of an agon stephanites around 230-220. The festival is not attested in the period 171-146. Lebadeia established the Trophonia (some time before $140 \mathrm{BCE}$ ), which 
were celebrated until $c a 80$ BCE. The Basileia did not exist in this period. After $c a 80 \mathrm{BCE}$, when the Boiotian Koinon was re-founded, the Basileia were re-established; the accounts of federal naopoi date to this period. The Basileia continued to take place, probably under the

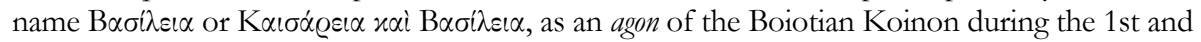
2nd cent. CE. It is not attested in the early 3rd cent. CE. Probably after the abolishment of the Boiotian Koinon ( $c$ a 230-240), the city of Lebadeia re-inaugurated the Trophonia, which continued to take place until some time after $260 \mathrm{CE}$.

82) D. KNOEPfler, "De Delphes à Thermos : un témoignage épigraphique méconnu sur le trophée galate des Étoliens dans leur capitale (le traité étolo-béotien)", CRAI (2007) [2009], p. 1215-1253 [BE 2010, 351; SEG LVIII 498]: A treaty of alliance between the Aitolians and the Boiotians $\left(I G I X^{2} 1,170\right)$ contains a clause that refers to the publication of the treaty in Delphi and in several sanctuaries in Aitolia (Thermon, Lophrion) and Boiotia (sanctuary of Poseidon in Onchestos, Alalkomenai, sanctuary of Athena in Koroneia). In fr. a LL. 3/4, K.

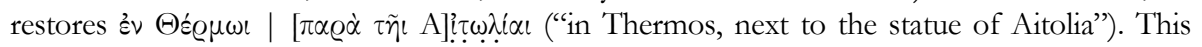
statue of Aitolia was a monument dedicated by the Aitolians to commemorate their victory over the Galatians in 279 BCE. The image of the seated Aitolia on Aitolian coins represents this statue and not the one seen by Pausanias in Delphi (10.18.7); the latter statue must have been a copy, on a smaller scale. K. discusses the appearance of the statue and its possible locations in Delphi and in Thermon.

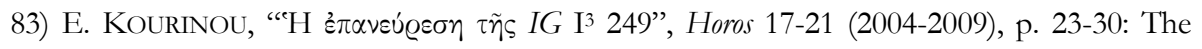
rediscovery and new examination of a fragmentary inscription from Athens (ca 440 BCE, IG I3 249) shows that the text is an account of hieropoioi.

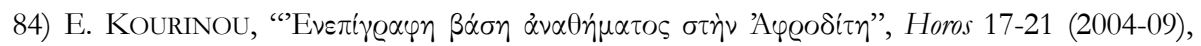
p. 23-30 [BE 2011, 237]: Ed. pr. of a dedication to Aphrodite Pontia (ca 350-300). This may be a stone found in 1903 in Sounion and subsequently lost (cf. SEG L 206). K. collects the evidence for the cult of Aphrodite Pontia (Nisyros, Kos, Histria, Olbia, Teiristasis, Erythrai, and Kyzikos).

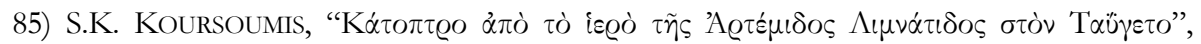
Horos 17-21 (2004-2009), p. 317-320 [BE 2010, 259]: A new study of a bronze mirror from the sanctuary of Artemis Limnatis on Mt. Taygetos (cf. Paus., IV, 4, 2-3) permits a reading of the

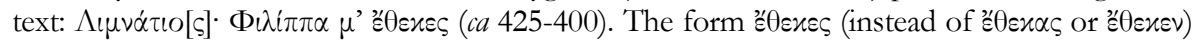
is hard to explain.

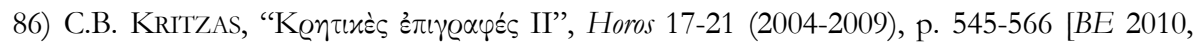
507; SEG LVIII 829, 830]: K. discusses a block from Phalasarna (Crete) with the inscription AIA $\Sigma$ (4th/3rd cent.; SEG XLVII 1409). According to Etymologicum Magnum 27.24, $\alpha \tilde{i} \alpha$ designates the wet nurse; as a mythological figure, she was a sister of Krete (A $\tilde{i} \alpha \cdot \dot{i} \pi \dot{o}$

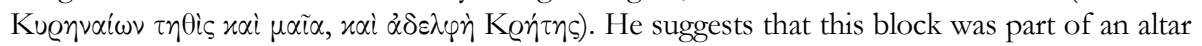
for the cult of Haia. It was found near the wall on which the name of the Nymph Akakallis was engraved (SEG XLVI 1234). This suggests a concentration of cults of local goddesses in this area.

87) A. Kropp, Defixiones. Ein aktuelles Corpus lateinischer Fluchtafeln, Speyer, 2008; ead., Magische Sprachverwvendung in vulgärlateinischen Fluchtafeln (defixiones), Tübingen, 2008; ead., "Sprachliche Betrachtungen zu den lateinischen defixionum tabellae auf der Grundlage einer elektronischen Datenbank", ActaAntHung 49 (2009), p. 77-93: In her two books, K. presents a corpus of Latin defixiones (Defixiones) and a linguistic analysis of these texts (Magische Sprachverwendung). In her article ("Sprachliche Betrachtungen"), K. presents the main results of her study, which focuses on the linguistic features of Latin defixiones. She recognizes four basic types of 'magical talk', 
which corresponded to ritual actions: a) the manipulation formula (e.g. ocullos, manus ... defigo in his tabellis), b) the transition formula (bunc ego apud vestrum numen demando, devoveo, desacrifico), c) the request formula (e.g. te rogo, obsecro ...; ... defigite, perfigite, consumite ...; Paulina adversa sit a viris omnibus et defixa sit), and d) the curse formula (exacror eum, qui ...).

88) Y. LAFOND, "Normes religieuses et identité civique dans les cités de Grèce égéenne (II" s. av. J.-C. - III s. ap. J.-C.)", in Norme -- religieuse, p. 321-334 [BE 2011, 266]: Adducing numerous inscriptions from Greece and the Aegean Islands, which refer to customary religious norms

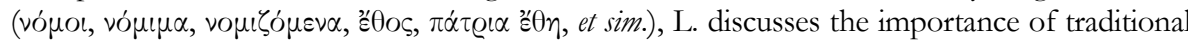
norms in the construction of a civic identity under Roman dominion. Insistence on these norms expressed the continuity of the polis, contributed to the socialization of the youth and to the introduction of the citizens to the religious values of the city, and provided models. For an earlier version of this article see $i d$., "Valeurs, normes et constructions identitaires. Les processus d'identification dans le monde gréco-romain”, CE $A 44$ (2007) [2008], p. 11-29.

88bis) R. Lane Fox, "The Letter to Gadatas", in G.A. Malouchou - A.P. Matthaiou

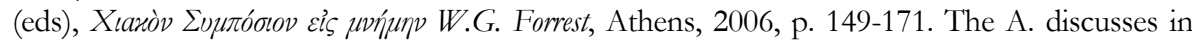
detail the letter of Dereios I to Gadatas concerning Apollon's sanctuary in Aulai, near Magnesia on the Maeander (I.Magnesia 115), which he regards as authentic [see also infra no. 167]. Formulations, whose authenticity has been doubted, find parallels in Achaemenid texts or in Herodotos. L.F. does not, however, exclude the possibility that the "words here and there have been 'modernised'. ... With the passage of time, bits may simply have faded or perished from old documents. ... In-filling is not faking and it does not materially change the contents" (163). [When a document contains elements that are clearly late fabrications, then it has been 'contaminated' and cannot be regarded as 'essentially authentic', exactly as a woman cannot be 'essentially' a virgin or only partially pregnant. For the re-inscribing old (or allegedly old) texts and the refined techniques of ancient forgers, see A. CHANIOTIS, Historie und Historiker in den griechischen Inschriften, Stuttgart, 1988, p. 234-277. What is relevant for the determination of the authenticity of a document is not the (expected) presence of seemingly authentic elements, but the presence of clearly later intrusions; the letter to Gadatas needs to be examined under this perspective; in my view, it is a fabricated document, possibly inspired by an authentic tradition.] L.F. argues that the original document probably dates to 512 BCE, when Dareios I received in Sardis personnel from Apollon's temple, which protested against Gadatas' actions. Gadatas, possibly the satrap of Ionia or Karia, had transplanted crops and trees from the East; L.F. suspects that the sacred personnel, known to have rushed down the steep cliffs of Aulai during a ritual and to have torn trees by the roots, had uprooted some of Gadatas' transplanted trees. Gadatas punished them by obliging the sacred gardeners (iseoi yutoveyoí) to dig land outside their temple. The shrine's senior priests must have appealed to Dareios, who ruled in their favor (cf. Herod., VI, 97, on instruction given by Dareios to Datis not to harm Delos). Dareios' reference to his respect towards Apollo is not evidence for his religious tolerance but for his respect toward oracles. The publication of the letter to Gadatas is probably connected with a dispute concerning control and taxation of sacred land. The letter may have been presented to Hadrian in 129 A.D. during the emperor's journey through Asia Minor and inscribed shortly after.

89) A. LiLlo, "Sobre la primera epifanía de la llamada Crónica de Lindos", in Estudios de Epigrafia Griega, p. 145-154: The text of the first epiphany of Athena Lindia in the Anagraphe of Lindos (I.Lindos 2) refers to a miracle of the goddess during the First Persian War. In view of the text's Ionian traits, very similar to the language of Herodotus, L. argues that the original was written in the Ionian dialect and that Dorian elements were added later. 
90) A. Lo Monaco, "Il culto di Nerone in Grecia. Immagini e cerimoniale della festa", in Pathways to Power, p. 43-71: L. discusses the cult of Nero in Greece, focusing on the iconography of the emperor (p. 43-62) and the ceremonies of the cult (association with traditional cults;

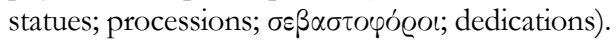

91) M. Luni - S.M. MAREngO, "Le Dioskourion de Battos découvert à Cyrène dans le Quartier de l'Agora", CRAI (2008) [2010], p. 11-36 [BE 2010, 631; SEG LVIII 1838]: L. summarizes the results of the excavation of a sanctuary founded in the late 7th cent. in Kyrene. A graffito

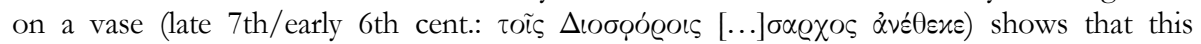
sanctuary was dedicated to the Dioskouroi. The existence of a Dioskourion on the street constructed by Battos, to be used for processions in honor of Apollon, was known from a Hellenistic Scholion (Schol. Pind. Pyth. V 93). [Cf. id., in A. Laronde - J. LeClant (eds), Journée d'hommage à François Chamoux, Paris, 2010, p. 105-127. C. Dobias-Lalou, BE 2010, 631,

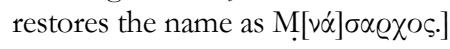

92) W. Luppe, “Zur Anzahl der an den Lenäen von den Tragikern aufgeführten Dramen", AfP 55 (2009), p. 36-39: After review of $I G \mathrm{II}^{2} 2319$, L. argues that the two tragic poets, who competed at the Lenaia, produced at least two (possibly three) tragedies and a satyr play (not just two tragedies).

93) A. Magneldi, “Gortina VII. Le iscrizioni dall'età arcaica all'istituzione della provincia romana”, RAL Ser. 9, 19 (2008), p. 233-334 [BE 2010, 503-504; SEG LVIII 977, 986, 992, 993, 998-1000]: M. presents 35 inscriptions from Gortyn. We mention only the inedita. The most important text of religious significance is very fragmentary, preserved in three pieces (p. 262-272 no. 9, ca 250-200). M. interprets the text as a treaty between Gortyn and another

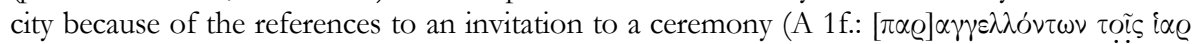

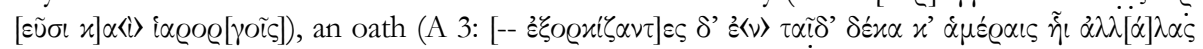
$\varepsilon \pi \alpha \varrho \dot{\alpha} \varsigma \hat{\eta} \pi \varepsilon \varrho i \tau[--])$ [this is syntactically not in order], and probably an extra-urban sanctuary on the frontier between two or more cities. M. suspects that the text also stipulates the payment of a fine by a magistrate who neglects a sacrifice in the sanctuary for which he was responsible

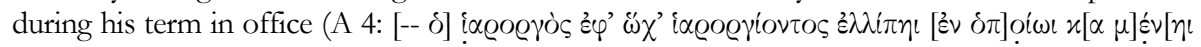

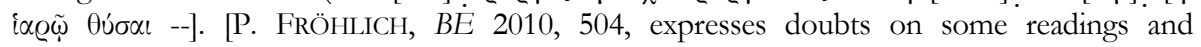
interpretations, observing that the text may be an internal regulation in Gortyn. I think that the text is a treaty (because of the reference to guarantors), but it may be an agreement between Gortyn and one of its dependent communities; cf. CHANIOTIS, Verträge nos. 66-67 and 69. The reading of A 3 cannot be correct due to its syntactical anomalies. In A 4, I suggest reading

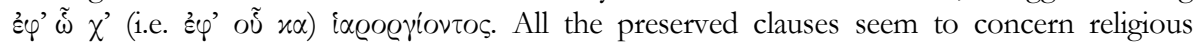
matters (cf. the mention of an hiarorgos), and more specifically the rituals in a sanctuary. If the

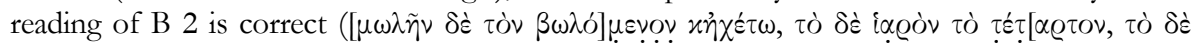

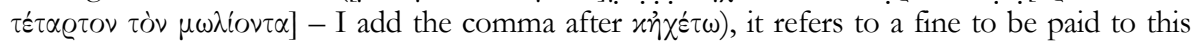
sanctuary: "let whoever wishes proceed (i.e. exact the fine) and keep it (the fine); and the

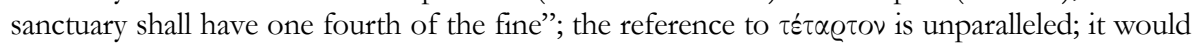
make sense, if the fine was divided among four parties: the volunteer ( $\delta \beta \omega \lambda$ ó $\mu \varepsilon v o \varsigma$ ), the sanctuary, and probably Gortyn and its partner]. Among the other texts, we mention two fragmentary inscriptions referring to building activities or dedications in sanctuaries, as one may infer from references to a biarorgos (304-306 no. 22 and 315-318 no. 28; 1st cent. BCE). M. also republishes three commemorative graffiti found in the area of a sanctuary on the acropolis of Gortyn (292-294 nos. 16-18, early 2nd cent. BCE; cf. G. RiZZA - V. SANTA MARIA SCRINARI, Il santuario sull'acropoli di Gortina, Rome, 1968, p. 60 and 62f.). Men inscribed their

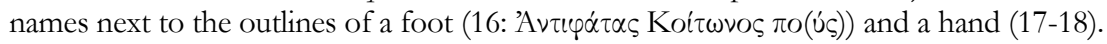


94) A. MAGNELLI, "Kleobis e Biton a Delfi: realità o leggenda?", in Estudios de Epigrafía Griega, p. 81-91 [BE 2010, 353]: A revision of the inscriptions on the plinth of the famous kouroi of Delphi, often identified as statues of Kleobis and Biton (SEG XXXII 549; XLI 521), leads M. to the tentative interpretation that the statues represented winners of the dromos contests at the Pythia.

95) A. MAKReS, "Unpublished Ephebic List in the Benakeion Museum of Kalamata", in Greek History and Epigraphy, p. 185-200: Ed. pr. of a list of ephebes found at Vounaria (near Nea Koroni) in south Messenia (127 BCE). The list is dated with reference to a priest of Apollon Maleatas. This is the first attestation of his cult in Messenia, though the cult is known in Epidauros, Sparta, and Kynouria. M. attributes this ephebic catalogue to Messenian Asine, where Pausanias (IV , 34, 11) mentions a temple of Apollon. The Asinians were expelled from the Argolid in the late 8th cent. BCE. The cult of Apollon Maleatas in Messene may have been connected with their efforts to demonstrate their Dryopian identity.

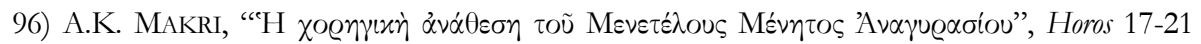
(2004-2009), p. 109-117 [BE 2010, 197]: A new critical edition of $I G I^{2} 3038$ (Athens) indicates that the base bears two separate inscriptions. The base was first used for the dedication of the choregos of the Erechtheis, winner in the men's chorus competition (early 4th cent.). In the late 4th cent., the base was re-used for an honorary statue made by Nikomachos. This interpretation resolves the anomaly of having a sculptor's signature on a choregic monument.

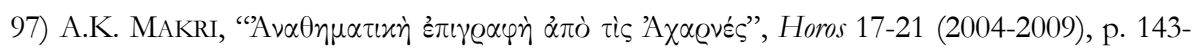
146 [BE 2011, 223]: Ed. pr. of the dedication of a gymnasiarch, whose team was victorious (in the torch race) at the Great Panathenaia (Acharnai in Athens, ca $350 \mathrm{BCE}$ ). The monument possibly comes from the sanctuary of Athena Hippia.

98) H. MALay - M. Ricl, “Two New Hellenistic Decrees from Aigai in Aiolis”, EA 42 (2009), p. 39-60 [BE 2010, 522]: Ed. pr. of a very important inscription from Aigai (p. 39-47), which concerns the establishment of divine honors for Seleukos I and Antiochos I immediately after their victory over Lysimachos in Kouropedion (281 BCE); the epithet Soteres was awarded to the kings because of this victory. [However, the fact that the monthly sacrifice to the kings was

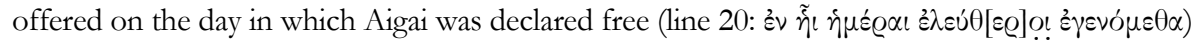
shows that the award of freedom to the city was the reason for the introduction of the cult: Seleukos and Antiochos were the 'rescuers' of Aigai. The declaration of freedom was, of course, a result of the victory at Kouropedion]. The very detailed description of the honors awarded to Seleukos and Antiochos makes this text one of our best (and earliest) sources for the civic cult of Hellenistic rulers. The beginning of the decree is not preserved and the first

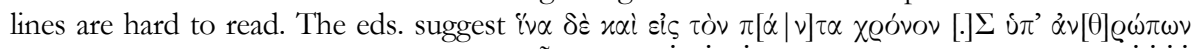

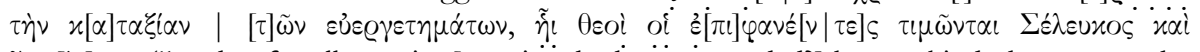
'Av [io] Xos ("so that for all eternity [remains the honor awarded?] by mankind, the one worthy of their benefactions, with which Seleukos and Antiochos, gods who have manifested themselves, are honored"). [This reading is, however, grammatically and syntactically impossible. Where is the noun to which the adjective $\tau \dot{\eta} \nu x[\alpha] \tau \alpha \xi i \alpha \nu$ refers? How can the Aigaieis refer to honors established by all of mankind, when the honors in this decree were established only by them and for a benefaction from which they - and they alone - profited (see lines 58-60: "we shall hand down to posterity the everlasting memory of his benefaction and that we shall make known to all of mankind that we are crowning them")?]. The decree introduces the following honors: A temple (vaós) was to be built next to the precinct of Apollon. In the precinct of this new temple, two cult statues $(\dot{\alpha} \gamma \alpha \dot{\alpha} \lambda \mu \alpha \tau \alpha)$ would be erected; inscriptions would identify them as Seleukos and Antiochos. Additional features of this new sanctuary include an altar and a statue of Soteira (probably Athena Soteira) in front of the 
temple and an altar (as "the altar of Seleukos and Antiochos, the Soteres") opposite the temple. During a sacrificial festival (hekatombe) bulls would be sacrificed to Seleukos and Antiochos Soteres [as P. HAMON, BE 2010, 522 (p. 830), points out, this hekatombe was offered during an existing festival of Apollon, with which the new cult was associated]. Following the model of a sacrifice offered to Apollon, women selected by lot would offer a sacrifice (lines

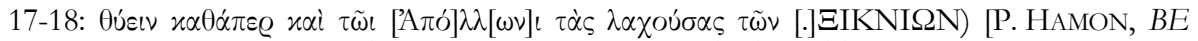
2010, 522 (p. 830), observes that it is unlikely that women sacrificed to male gods; there must be something wrong with the reading (or a mason's mistake]. In addition to this [annual] sacrifice, two further sacrifices were offered on a monthly basis, on the day that Aigai gained its freedom. After a fragmentary passage, the decree refers to the creation of two new tribes named after Seleukos and Antiochos, which would be added to the city's four tribes. Further cultic honors are not preserved, but they were connected with the Dionysia and another festival (line 33). A bull was sacrificed in the month Seleukeon, in the same manner as the sacrifice offered to Apollon in the month Thaxios. [If the Aigaieis decided to name a month after Seleukos on this occasion, this was mentioned in the lost part of the decree]. A priest for the new cult would be elected from among all the citizens on an annual basis. His insignia were a laurel wreath, a headband ( $\sigma \tau \varrho o ́ \varphi ı v)$, and a splendid dress. The priest would accompany the

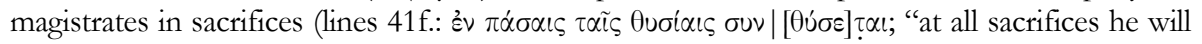
consult the gods") [the restoration $\sigma u v \mid[\theta \dot{\sigma} \sigma \varepsilon] \tau \alpha l$ is problematic; P. HAMON, BE 2010, 522, more plausibly suggests $\sigma \cup \nu[\varepsilon \sigma \sigma] \tau \iota$ or $\sigma \cup \nu[\varepsilon \sigma \tau \iota \alpha \sigma \varepsilon] \tau \alpha l]$. During all meetings of the assembly he

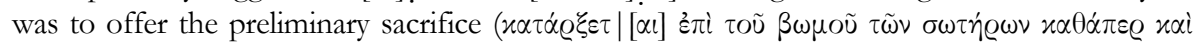

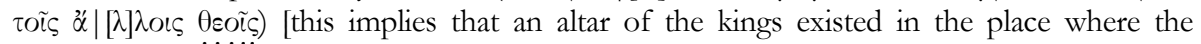
assembly convened]. A fragmentary passage refers to something done by the bierokeryx during all public sacrifices in honor of Seleukos and Antiochos Soteres [P. HAMON, BE 2010, 522, restores [ $\left.\varepsilon^{u} \chi \varepsilon \sigma \theta \alpha l\right]$ : the sacred herold included the kings in the prayers. The nominative subject

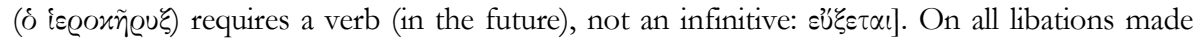
before the magistrates, incense would be offered and vows [or prayers] recited (lines 48f.: $\delta$ ó

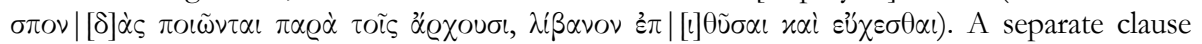
refers to honors on the occasion of the musical contest - according to the editors this was a contest in a new agon established for the kings [but it may well be an already existing contest, in the Dionysia or in the festival of Apollon (as the singing of a paean implies); cf. P. HAMON, ibid.]. The winner of the contest was to sing a paean in connection with libations (lines 49-51:

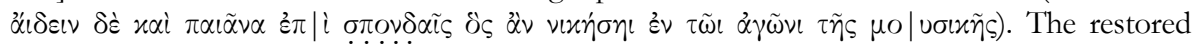
prytaneion was named Seleukeion, the seat of the strategoi was named Antiocheion. Copies of this decree were erected in the sanctuary of Apollon and in the sanctuary of Athena, near the altar of Zeus Soter. An embassy to Seleukos would announce the honors and assure him that the Aigaieis "shall hand down to posterity the everlasting memory of his benefaction and shall make known to all of mankind that we are crowning them with the beautiful crown of glory

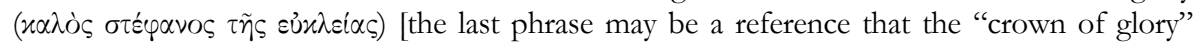
would be announced during a Panhellenic festival. See the remarks of M. SĖVE, BE 2010, 522 (p. 831f.) on the building measures and the statues].

A second inscription from Aigai (p. 48-53) contains part of a decree of the Thessalians granting ateleia, citizenship, and right of marriage to the Aiolians, Koans, and Magnesians of the Maiander (late 3rd cent.?). The decree was proposed during the celebration of the Thessalian Olympic festival, which is attested in this inscription for the first time. Speudon, the priest of Zeus Olympios announced the gratitude of the Thessalians at the Thessalian Olympic

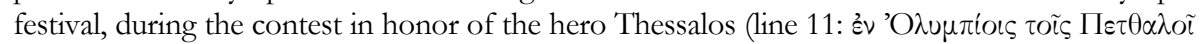

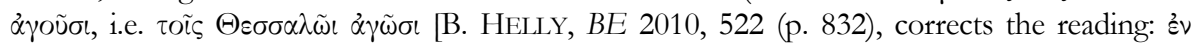

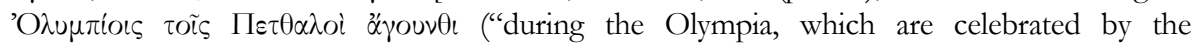


Thessalians"). The Olympia were possibly established in the same time as the Leukophryena of Magnesia or the Asklepieia of Kos and Mytilene. This would explain Straton's trip in Asia Minor: he sought the recognition of the festival]. As the priest of Zeus Olympios reported, the Aiolians, Koans, and Magnesians of the Maiander "have established a festival and a sacrifice

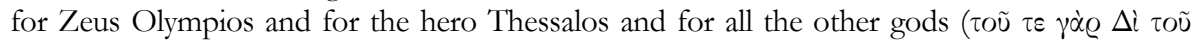

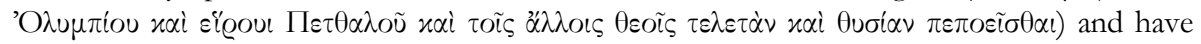
prayed that all Thessalians and their own citizens jointly enjoy security, prosperity, fertility". [B. Helly, ibid. (p. 832f.), rightly points out that no new festival was established; the Aiolians etc. made an one-time celebration and sacrifice, possibly separately, in each city. Indeed, the participle $\pi \varepsilon \pi о \varepsilon i \sigma \theta \alpha \iota$ indicates a one-time event, not the establishment of a periodic festival.] The eds. comment on the kinship between the Thessalians and the Aiolians and the diplomatic relations of the Thessalians with Magnesia and Kos. According to myth, Thessalos, one of several heroes with this name, was king of Kos. Also Podaleirios, Asklepios' son, connected Kos with Thessaly. [As regards Magnesia on the Maeander, the eds. refer to Thessalian decrees recognizing the Leukophryena. But the relations of the Magnesians with the Thessalians were deeper: the very foundation legend of Magnesia starts in Thessaly, Leukippos' fatherland]. The decree was inscribed in the sanctuary of Zeus Olympios, in Itonos, and in the sanctuary of Apollon Kerdoios in Larisa. The inscriptions should also list the names of the cities that participated in the sacrifices for Zeus Olympios and in the contest.

99) S.M. MAREnGo, "Dédicace aux Dioscures et d'autres graffiti", CRAI (2008) [2010], p. 2536. Ed. pr. of a graffito on a Chian cup dedicated to the Dioskouroi (Kyrene). This is one of the earliest attestations of the cult of the Dioskouroi in the Greek world (cf. IG XII 3, 359; $L S A G$ p. 168 no. 3; p. 357 no. 31; p. 215 no. 11; p. 234 no. 5; p. 200 no. 24). Another nine graffiti are very fragmentary.

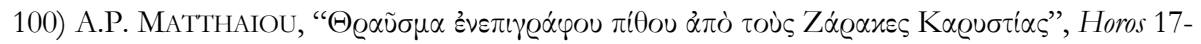
21 (2004-2009), p. 541-544 [SEG LVIII 962]: Five adjoining fragments of a clay pithos with a relief representation of Centaurs and hares were found in the sanctuary of Apollon Delios in Zarax/Euboia (ca 650-640 BCE). An inscription gives the name of the potter and possibly

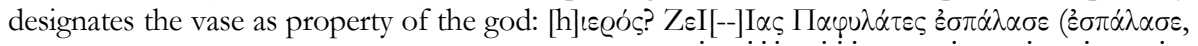
from $\sigma \varphi \alpha \lambda \alpha \sigma \sigma \sigma \omega:$ 'to cut, to sew'; a description of the technique used in the making of relief jars).

101) V. MeHL, "Parfums de fêtes. Usage de parfums et sacrifices sanglants", in Sacrifice antique, p. 167-186: M. discusses the letter of Seleukos I to Didyma, in which the king lists his offerings to Apollon of Didyma, including large amounts of different perfumes - incense, myrrh,

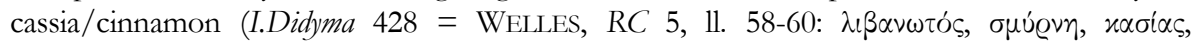

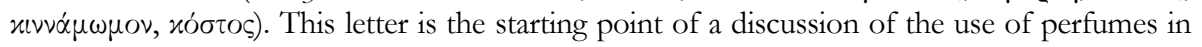
sacrificial rituals and its significance for purification and communication with the gods. M.

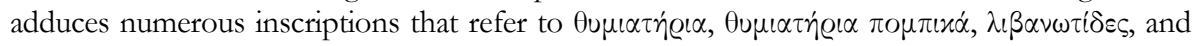
$\lambda \_\beta \alpha \nu \omega \tau \varrho^{\prime} \delta \varepsilon \varsigma$. [For a new attestation of a libanotris in the cult of Zeus Thynnaretes (Aphrodisias), see A. Chaniotis, "Aphrodite's Rivals: Devotion to Local and Other Gods at Aphrodisias”, CGG 21 (2010) [2011], p. 246 no. 16.]

102) J. MejER, “A Note on a Dedication to Artemis in Kalydon”, in T. FISCHER-HANSEN B. Poulsen (eds), From Artemis to Diana. The Goddess of Man and Beast, Copenhagen, 2009 (Acta Hyperborea, 12), p. 79-81: Ed. pr. of a dedication to Artemis by a man (Kalydon, late Hellenistic). 
103) L. MEIER, “Inschriften aus dem Asklepieion von Pergamon”, Chiron 39 (2009), p. 395-408 [BE 2010, 520]: Ed. pr. of seven inscriptions found in the Asklepieion of Pergamon. A building inscription refers to the dedication of an unspecified building (the theater?; 1, 1st/2nd cent.). Four dedications were made to Asklepios Soter (by an imperial freedman in fulfilment of a vow: 3, 2nd cent. CE; by a priest of Apollon Sykiessenos and bieronikes: 6, 1st/2nd cent.) and to Asklepios and Hygieia (by a woman on behalf of a man: 5, 1st/2nd cent.; by a banker as

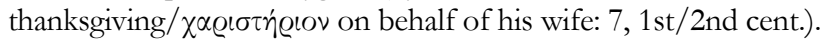

104) J. MÉndez DosunA, “¿Un nuevo testimonio de $\alpha \tilde{i} \zeta \alpha$ 'cabra' en una lámina órfica?”, in Estudios de Epigrafia Griega, p. 369-375 [BE 2010, 360]: The Orphic lamella from Pelinna (SEG XXXVII 497; EBGR 1994/95, 148 with further references) contains the formula $\tau \alpha \tilde{u} \varrho o \varsigma$ si

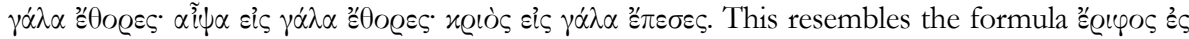

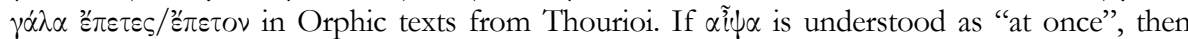

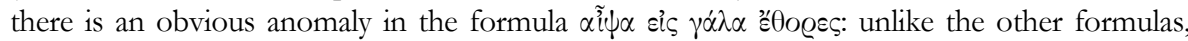
which refer to domestic animals with horns leaping into milk, this one lacks a reference to an animal. This problem is solved if one assumes that the original text read $\alpha \tilde{i} \zeta \alpha=$ "goat".

105) L. MigeotTE, "L’apport des inscriptions à l'étude des finances publiques et sacrées des cités grecques", in Estudios de Epigrafía Griega, p. 251-260: M. summarizes the contribution of epigraphy to the study of the finances of sanctuaries (sacred resources, expenses, financial administration).

106) S. MitChell. "The Imperial Cult in Galatia from Claudius to Trajan", in Festschrift Schwertheim II, p. 471-483: 1) Ed. pr. of a fragmentary dedication that mentions a man who held the priesthood of Divus Augustus and the priesthood of Claudius (near Ayaş, reign of

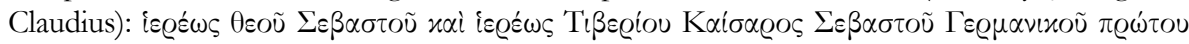

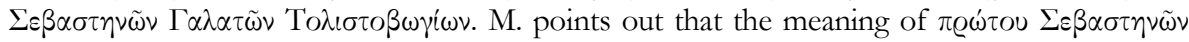

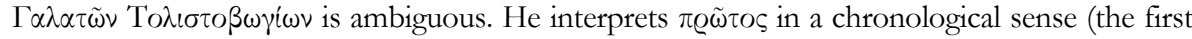
to have occupied this position in the cult of Claudius or the first of his tribe to have served in this function) rather than in a hierarchical one [given the existence of the title $\pi \varrho \tilde{\omega} \tau 0 \varsigma$ 'E $\mathrm{\lambda} \lambda \eta \dot{\nu} \nu \omega \nu, \pi \varrho \tilde{\omega} \tau O \varsigma$ 'A $\chi \alpha i \tilde{\omega} \nu$ et sim., I suspect that the expression $\pi \varrho \tilde{\omega} \tau O \varsigma, \sum \varepsilon \beta \alpha \sigma \tau \eta \nu \tilde{\omega} \nu \Gamma \alpha \lambda \alpha \tau \tilde{\omega} \nu$

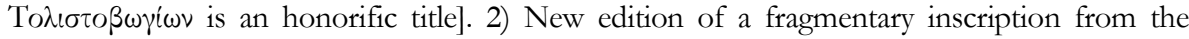
north anta of the temple of Augustus in Ankara (reign of Trajan; IGR III 158). It is the beginning of a list of high priests, who promised to make contributions to constructions

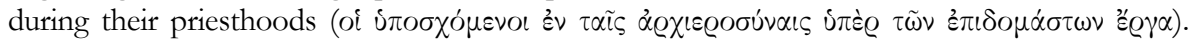
The priests of the imperial cult were 'promoted' from priests to high priests some time in the second half of the 1st cent. CE. Only the name of the first contributor survives, the priest of Theos Sebastos, M. Cocceius Seleukos. His contribution is not entirely preserved, however; it

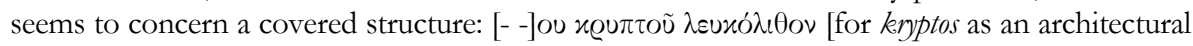
term see CID II 53; the context suggests that the construction in question was a portico or a

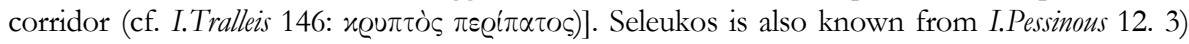
Taking into consideration the evidence for other early high priests in Galatia, M. presents a list of five high priests from $c a 41 \mathrm{CE}$ to $c a 120 \mathrm{CE}$.

107) M.C. MonAco, “Sull'Acropoli, all'ombra della Promachos", ASAA 87 (2009), p. 274-311: M. examines the uses of the area of the Acropolis of Athens near the colossal statue of Athena Promachos, and in particular its function as an epiphanestatos topos for the display of epigraphic documents and other monuments. Since the statue was dedicated by the Athenians and funded by the allies after the Persian Wars, some of the monuments were closely connected with the Greek victory over the Persians and the ideology of the Athenian hegemony. The texts selected to be displayed there include the decree that declared Arthmios of Zeleia a traitor 
during the Persian Wars (cf. Demosthenes, 19, 272, 1-2), possibly the inscription concerning the aparche, the Athenian Tribute Lists (IG $\mathrm{II}^{2}$ 259-272), the citizenship decree for Euagoras, King of Salamis ( $I G \mathrm{I}^{3}$ 113), and the treaty between Athens and Chios ( $\left.I G \mathrm{II}^{2} 34\right)$, which became the model for the Second Athenian Allance [the A. is wrong in the assumption that only C. Habicht regards this decree a forgery of the 4th cent. (p. 281 note 49); see e.g. A. CHANIOTIS, Historie und Historiker in den griechischen Inschriften, Stuttgart, 1988, p. 242, 258-262. If the decree was erected in the 4th cent., M.'s chronological reconstructions need to be reconsidered]. On the contrary, the location of the Athenian trophy of their war against the Boiotians and the Chalkidians (erected in 507 and restored in 457 or 446 BCE) cannot be determined with certainty.

108) M. Muller-Dufeu - E. SHEHI, “Skyphoi avec dédicaces peintes de l’Artémision d'Épidamne-Dyrrhachion", BCH 133 (2009), p. 99-112: Ed. pr. of two inscribed ostraka of large skyphoi from a sanctuary that can now be identified as the Artemision of Epidamnos (cf. Appian, II, 60). The vases (late 4th cent.) are inscribed with dedicatory inscriptions painted with large red-figure letters highlighted in red outline. One of the skyphoi was dedicated to Artemis, the other to Hekate (or Artemis Hekate). The vases were commissioned to serve as dedications.

109) E. MuÑz Grijalvo, "Elites and Religious Change in Roman Athens”, Numen 52 (2005), p. 255-282 [SEG LV 30]: M. argues that inscriptions show a markedly conservative Athens as regards religion (continuation of the worship of the traditional gods, continuation of rituals); the only divine newcomers were the Roman emperors, but their worship did not alter public worship and its rituals. Two important changes were the 'oligarchization' of religious power (cf. the disappearance of the temple inventories that reflected democratic accountability, the stronger dependency of public religion on funding from the elite and the emperors, the lifetime tenure of the priesthood of Asklepios), and a new religiosity connected with the power of the elite, which explains the popularity of the cults of Asklepios and Isis, mainly supported by the Athenian elite. The Eleusinian endowment (IG II ${ }^{2}$ 1092, ca $165 \mathrm{CE}$ ) is evidence for the display of piety and tradition by the elite. The worship of Julia Domna as Athena Polias (IG II ${ }^{2}$ 1076) also expressed loyalty towards a traditional cult (cf. the link of the imperial cult with the Panathenaia and Zeus Eleutherios). The cult of Eukleia and Eunomia likewise demonstrates attachment to tradition (IG II $\left.{ }^{2} 3738,4193,5059\right)$.

110) F.S. NAIDEN, "Sanctions in Sacred Laws", in E. HARRIS - G. THÜR (eds), Symposion 2007. Vorträge zur griechischen und hellenistischen Rechtsgeschichte (Durbam, 2.-6. September 2007), Vienna, 2008, p. 125-138: After pointing to the problems associated with the term 'sacred laws', N. gives an overview of sanctions (fines, exile, curses, ban from the sanctuary and its rites, liability to asebeia) imposed for violations of ritual norms, adducing numerous cult regulations (inter alia Athens: $I G I^{2}$ 334, 1237, 1361; LSSG 55; Olympia: IvO 9; Andania: LSCG 65 = IG V.1.1390; Akraiphia: IG VII 4135; Delphi: CID I 10 = IV 1; Amphipolis: ISEG XLIV 505; Astypalaia:

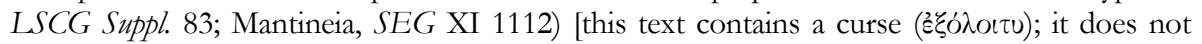

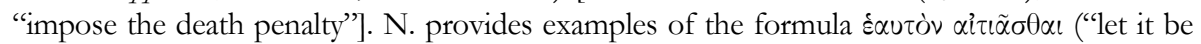
on the violator's conscience"; e.g. I.Tralleis 235; SEG XXVI 1225; LSAM 85; I.Ephesos 1520, etc.; p. 132). Cf. M. DrEHER, “Antwort auf F.S. Naiden”, ibid., p. 139-144.

111) E. Nieto IzQuierdo, “A propósito de una inscripción encontrada en el Hereo de Argos: IG IV, 507”, in Estudios de Epigrafia Griega, p. 101-104. On the basis of linguistic features and the lettering of an archaic dedication to Hera, found in the Argive Heraion (IG IV 507), the A. ascribes the text to Kleonai-Nemea and dates it to $c a 575-550$. 


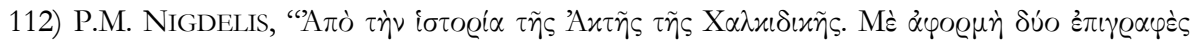

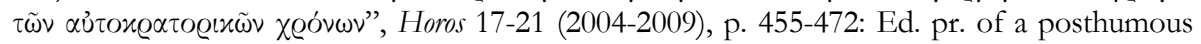
honorary inscription for a priest of [Zeus Oura]nios - rather than [Kerau]nios (2nd cent. CE) -, kept in the monastery of Megale Lavra (Athos); its provenance, possibly Akrothooi (Chalkidike) or Thasos, is unknown.

113) P. Nigdelis - E. Sverkos, "Zur Neudefinition des Territoriums einer makedonischen Polis der Kaiserzeit: der Fall von Bragylos in Krestonia", ZPE 169 (2009), p. 163-172 [BE 2011, 422]: Ed. pr. of a boundary stone from Bragylos, which refers to the delimitation of its territory under a king Philip (probably Philip II). The boundary stone was restored by the governor Clodius Capito Aurelianus (Macedonia, 2nd cent. CE). A beroon was used as a

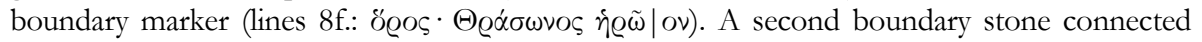
with the same delimitation was already known (SEG XXXIX 577). The new text shows that it

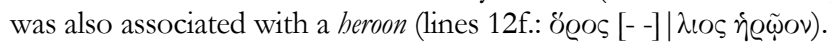

114) M.J. Osborne, "Five Hellenistic Decrees of the Salaminian Thiasotai of Bendis", Horos 17-21 (2004-2009), p. 657-672 [BE 2011, 236]: O. presents improved editions of the five known decrees of the Salaminian association for the cult of Bendis (Salamis, 273-242 BCE). Four of these decrees honor the annual officials of the thiasos (priest, secretary, treasurer, synepimeletai) for their services and the performance of sacrifices (IG $\mathrm{II}^{2} 1317$; IG $\mathrm{II}^{2} 1317$ b+add.; SEG II 10 + LIII 162; SEG LIV 60). The fifth decree (SEG II 9 + LIII 159) honors retrospectively all the officials of the thiasos who served from the archonship of Polyeuktos to that of Theophemos (250/49-247/6). A study of the officials of the year 249/8 shows that there were two groups of thiasotai: one (the original one) on the acropolis of Salamis, the second in the harbor area. The latter one must have been established during or immediately after the archonship of Polyeuktos, in the context of the military events around the revolt of Alexandros, son of Krateros (250 BCE). The new association did not immediately follow the practice of setting up annual inscriptions with the honored officials, and this explains the retrospective honorific decree (one of the honored officials was Batrachos, the man who proposed the decree).

115) R. ÖZGAN - C. ÖZGAN, “2005 yll Knidos kazıları”, KST 28.1, 2007, p. 649-668. 654 and 662 [SEG LVIII 1219]: Ed. pr. of a dedication of a stoa to Apollon Karneios (Knidos, Imperial period; p. 654 and 662).

116) D. Pantermalis, "Aĩov 2006”, AEMTh 20 (2006) [2008], p. 567-575: P. reports the discovery of a bath complex in Dion, in which marble plaques from a sanctuary were reused. He mentions fragments of plaques with footprints and a fragmentary dedication to Asklepios Soter (2nd/3rd cent.).

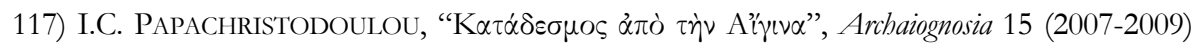
[2010], p. 55-67: Ed. pr. of a lead tablet from Aigina with a judicial curse. The text narrates a bistoriola referring to Hephaistos binding an unknown god (Ares?) and Zeus binding Prometheus. [This interesting text, republished in $I G I^{2} 2,1012$, has already been discussed in EBGR 2008, 62.]

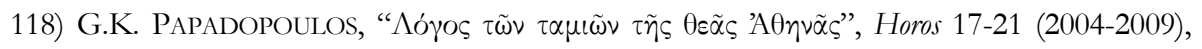
p. 73-81 [BE 2010, 198]: Ed. pr. of a fragment of an account of the treasurers of Athena (Athens, ca 371/0). Preserved in the text is a section listing the metal objects that were kept in the Chalkotheke. The same objects are listed in the account of the following year (cf. IG II ${ }^{2}$ 1424 a 255-273). The new text shows that the large lamp (line 22) was of iron, not silver (as erroneously stated in $I G I^{2} 1424$ a 269$)$. 
119) D. Papanikolaou, "The Aretalogy of Isis from Maroneia and the Question of Hellenistic 'Asianism”', ZPE 168 (2009), p. 59-70 [BE 2010, 412]: In this convincing study, P. demonstrates that the aretalogy of Isis from Maroneia (I.ThracAeg. E205) belongs to a Hellenistic oratorical tradition that should not be characterized as 'Asianic', although it was very popular in Asia Minor. It is the only surviving sophistic encomium to a deity of the Hellenistic age. The religious oratory of the type known from Aelius Aristides' prose hymn to Sarapis as well as the prose hymns of Himerios was not invented during the Roman period. The anonymous author was a 'sophist' or 'sophistic orator' who specialized in epideictic declamations, including encomia of gods, heroes, human beings, and animals. The most striking feature of the text is the presence of rhythmical clausulae throughout. The rhythmicality of this text is similar to that found in the fragments of Hegesias and Herakleides Kritikos, in the cult regulations of Antiochos I of Kommagtene in Nemrud Dag, and in some decrees. P.

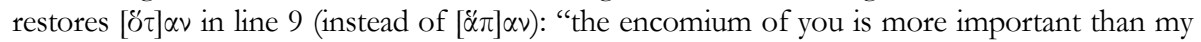
eyes. Whenever with the same eyes, with which I saw the sun, I see your beauty, I am confident that you will ever be here."

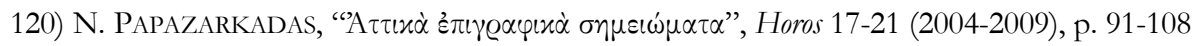
[BE 2011, 189]: P. discusses numerous Athenian inscriptions of religious significance. 1) New critical edition of $I G \mathrm{II}^{2} 1289$ (mid-3rd cent.). The text records an arbitration in a dispute that had arisen between two factions within the same association of orgeones over the administration of the property of a goddess. According to the verdict, the disputed land is property of the goddess; the association is not allowed either to sell it or to mortgage it. The revenues were to be used for sacrifices. The verdict of the judges is confirmed by the goddess and (according to P.'s restoration) her priest. 2) The text of the boundary stone IG II 2603 (republished also as

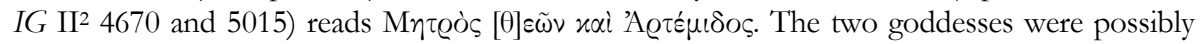
worshipped together in Agrai (cf. EBGR 2003, 158). Although the stone was found on the north slope of the Acropolis, it may come from the precinct of the two goddesses in Agrai. 3) The new edition of $I G I^{2} 2616$ shows that the inscription is the boundary stone of the sanctuary of Zeus Epopetes Nephalios (early 4th cent.). In the cult calendar of Erchia (SEG

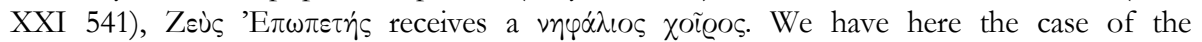
transformation of a ritual element into an epithet (cf. A. HENRICHS, "The 'Sobriety' of Oedipus: Sophocles OC 100 Misunderstood”, HSCP 87 [1983], p. 88-92). 4) IG II2 310 is a regulation concerning a temenos (cf. EBGR 2005, 90). P. suggests that it may concern the access

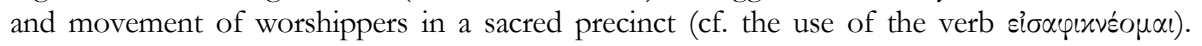
5) The sum that the priestess of orgeones in Piraeus received for the sacrifice of a bull was 1 drachma, not 1 or 1,5 obols $\left(I G I^{2}\right.$ 1361). 6) P. contributes several new readings of a subscription concerning the dedication of a statue ( $\left.I G I^{2} 2329\right)$.

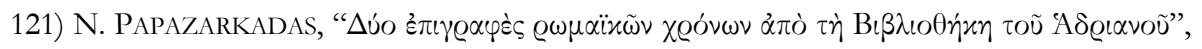
Horos 17-21 (2004-2009), p. 197-210: Ed. pr. of a very interesting funerary epigram inscribed

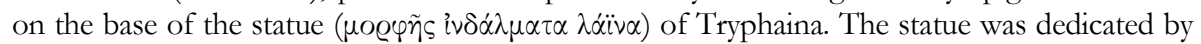
her father, Kalliphron. The final verses describe Tryphaina's blessed life in the Elysium and her

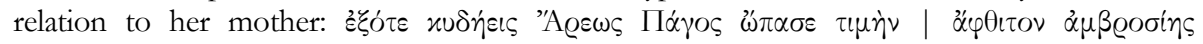

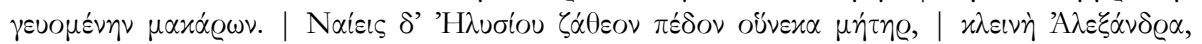

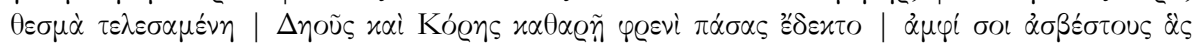

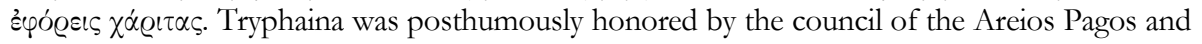
now tastes the ambrosia of the gods $(\mu \dot{\alpha} x \alpha \varrho \varepsilon \varsigma)$. [P. is certainly right in the assumption that the $\mu \dot{\alpha} x \alpha \varrho \varepsilon \varsigma$ are the gods (ambrosia is their exclusive food). The epigram conflates two ideas: the eternal symposium of the Blessed in the Elysium and the symposium of privileged dead in the company of the gods. The conflation of incongruous ideas is quite common in epigrams of the Imperial period with visions of the afterlife.] The initiation of Tryphaina's mother, Alexandra, 
into the Eleusinian mysteries is then mentioned, and is somehow brought into causal relation with Alexandra's dwelling in the Elysium (ö̈vex $\alpha$ ). P. considers three possibilities: a) Tryphaina received the grace of afterlife in the Elysium because of Alexandra's initiation. b) Alexandra was initiated in order to contact her daughter in the underworld; the relation between mother and daughter mirrors that of Demeter and Kore [for a possible parallel, see supra no. 31 on an inscription from Knidos]. c) Alexandra met her daughter in the Elysium after her own death and thanks to her initiation; this would explain why the statue was dedicated only by Tryphaina's father. P. notes his preference for the third interpretation. [The first interpretation is to be excluded and a full stop should be place after $\pi \varepsilon ́ \delta o v ; ~ o u ̈ v e x \alpha$ mostly expresses the result of an action ('because of this'). The third interpretation is indeed more likely: Alexandra followed the example of her daughter and was initiated after Tryphaina's death, thereby receiving, thanks to the initiation, the same grace as her daughter used to have. I would tentatively translate: "since the noble Areios Pagos bestowed honors on you - you, who tastes the imperishable ambrosia of the blessed. And you dwell in the divine fields of Elysium. On account of this, your mother, the noble Alexandra, performed the customary rites of Deo and Kore with a pure mind, and has received, because of you ( $\alpha \mu \varphi i \sigma o t)$, all the inextinguishable grace, which you used to carry".]

122) N. Papazarkadas, "The Decree of Aigeis and Aiantis (Agora I 6793) Revisited", in Meletes Habicht, p. 165-181 [BE 2010, 189]: A new critical edition of a decree concerning the demarcation of land in Oropos between the tribes Aigeis and Aiantis (Agora XIX L8, ca 330 BCE or later) shows that there is a reference to a sanctuary of Herakles in line 133. P. proposes that this sanctuary be identified with the one at modern Sykaminon, known from a dedication (IG VII $436=$ I.Oropos 510). Consequently, the land in question must have been to the west of the Amphiareion of Oropos.

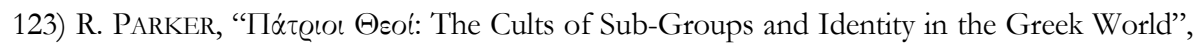
in A.H. Rasmussen, S.W. RASmussen (eds), Religion and Society. Rituals, Resources, and Identity in the Ancient Graeco-Roman World, Rome, 2008, p. 201-214: In connection with a discussion of the importance of ancestral gods to the identity of sub-groups in the Greek poleis, P. provides a thorough survey of the divinities that were worshipped with the cult epithet $\pi \alpha \tau \varrho \tilde{\omega} \iota \varsigma / \pi \alpha \tau \varrho \omega \dot{ } \iota \alpha$ et sim. The cult epithet $\pi \alpha \tau \varrho \tilde{\omega} \iota \circ / \pi \alpha \tau \varrho \omega \dot{\iota} \alpha$ was attributed to a large variety of gods and goddesses. They were worshipped both by individuals and groups above the level of the household and below that of the city (and the tribe?), groups based on fictive kinship. Important clusters of relevant epigraphic testimonia have been found in the Thesmophorion of Thasos, Kos, and Ephesos. A very useful catalogue of relevant inscriptions indicates the various contexts of the worship of $\pi \alpha \tau \varrho \tilde{\varphi}$ oเ $\theta \varepsilon o i$ by individuals, families, sub-polis groups, and the entire polis.

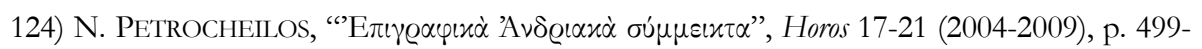
516: P. republishes a decree concerning the recognition of the Soteria in Delphi (F.Delphes III 1, 481, mid-3rd cent.) and attributes it to Andros (p. 499-502). He also republishes with several new readings and restorations (p. 502-513 a stele, inscribed on all four sides, which contains nine decrees of the Andrians in a period of a few years (IG XII Suppl. 248). P. argues that two of these decrees are recognition decrees of Andros for the Magnesian Leukophryena. The first

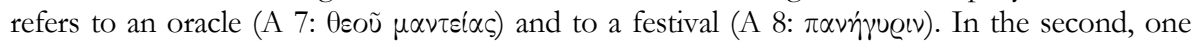
recognizes references to theoroi. According to P., the Andrians had already recognized the asylia and the festival in $208 \mathrm{BCE}$, but the plundering of Andros in 199 prevented them from attending the contest and necessitated a new recognition, when Eumenes II inherited the island in $197 \mathrm{BCE}$. [The restorations are very speculative, and there is hardly any similarity with 
the numerous other (very formulaic) recognition decrees. These two decrees seem to concern agonistic festivals, but there is nothing that suggests a connection with the Leukophryena.]

125) N. Petrocheilos, “A Rock-Cut Inscription on Andros”, Archaiognosia 15 (2007-2009) [2010], p. 69-76: Ed. pr. of an inscription engraved on a rock in the area of the east cemetery:

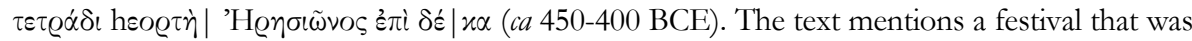
to take place in the cemetery on the 14th of the month Eresion. P. assumes that this was a ritual for the commemoration of the dead (cf. the Athenian Genesia). The month (cf. the Delian Aresion) is attested for the first time in Andros. [The use of the term छo@ mostly reserved, albeit not exclusively, for the cult of the gods, suggests that the celebration was not dedicated to the dead themselves, but rather to a deity, either a chthonic deity or a patron of families.]

126) G. PETZL, “Zwei bronzene Weihegaben”, ZPE 169 (2009), p. 89-94 [BE 2010, 68, 512]: Ed. pr. of an inscribed bronze handle(?) of an object (a vase or an incense burner) in a private collection. The object was dedicated to Athena Assesie by two men ( ca 500 BCE); its provenance must be Assesos (near Miletos; cf. Milet VI 3, 1278). Ed. pr. of a bronze lamp (unknown provenance, $2 \mathrm{nd} / 3 \mathrm{rd}$ cent.) dedicated to Meter Oreia by a man in fulfilment of a

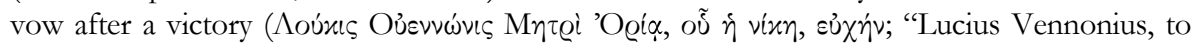
whom the victory belongs, to Meter Oreia as a vow"). P. gives a list of attestations of the cult of Meter Oreia in Asia Minor.

127) G. PETZL, "Bedrohter Kultvollzug: Hilfe von höherer Stelle", in Estudios de Epigrafía Griega, p. 377-386: Several inscriptions concern protests addressed by cult personnel to Roman governors against the efforts of cities to cut back expenses for the cult (SEG XLIX 1676; Milet I 9, 360; I.Ephesos 12). P. presents a new fragmentary inscription from Sardis (221 CE), which has a similar background. It seems to be a petition of a cult association, possibly worshipping

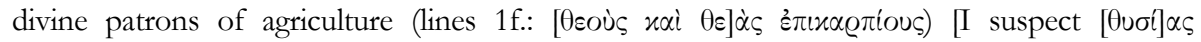

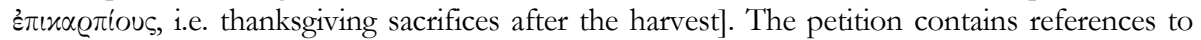
previous subscriptiones. The earlier decisions of governors confirmed the right of this group to

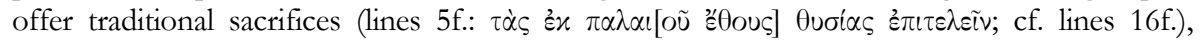
probably in connection with prayers for the wellbeing of the imperial house (lines $6 \mathrm{f}$.:

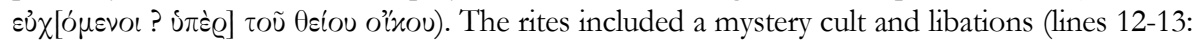

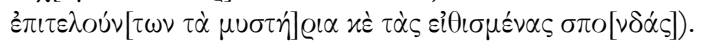

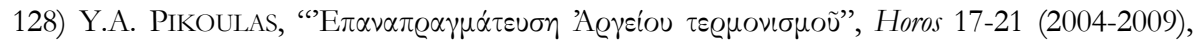
p. 279-296: New, improved edition of a delimitation of land from Argos (SEG XXXVI 336, ca 340-330). The text refers to cult places of Meleagros, Hermes, Pan, and possibly Polemokrates, along line of demarcation (possibly within the territory of Argos).

129) G. Pironti, "Des femmes, des magistrats, une déesse : réflexions sur les contextes de l'offrande", in Donateur, offrande, déesse, p. 39-50: A metrical dedication to Aphrodite from Lato (Crete, late 2nd cent.; I.Cret. I xvi, 24) reports that a group of magistrates (members of the board of eunomia) dedicated a temple to Aphrodite, requesting that the goddess grant them longevity in prosperity and free from harm. P.'s analysis of this text shows the co-existence of several layers of meaning and context: the perception of Aphrodite as a patron of magistrates, her relation to corporeality, and the specific historical context of the dedication (after a victorious war).

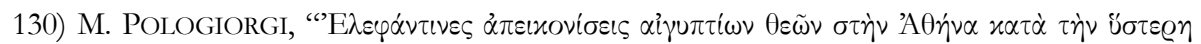

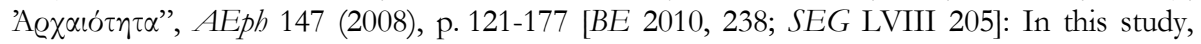
dedicated to the representation of Egyptian gods on ivory objects (Athens, Late Antiquity), P. refers to an unpublished dedication to Isis Tyche, Asklepios, and Hygieia, found south of the 


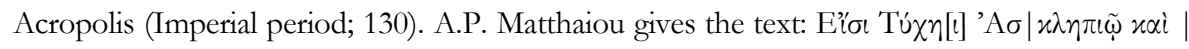

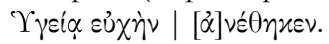

131) C. PrÊTRE, "La donatrice, l'offrande et la déesse : actions, interactions et réactions", in Donateur, offrande, déesse, p. 7-27: Exploiting the information provided by dedicatory inscriptions and inventories, P. recognizes three types of dedications made by women to female divinities: gifts of worshippers, donations of female benefactors for cult foundations, and dedications by priestesses. She examines the motivation for dedications, the relation between gender and votive offering - pointing to the difficulties in recognizing 'typical' female votives (with few exceptions) -, and the interference of external factors in the votive behavior of women.

132) C. PrÊtre - P. ChARLIER, Maladies humaines, thérapies divines. Analyse épigraphique et paléopathologique de textes de guérison grecs, Villeneuve d'Ascq, 2009 [BE 2010, 6]: The A. present the Greek text, French translation, and detailed commentary of a selection of healing miracles. The commentary refers to the language, the religious background, the diseases, and the healing methods. The following texts are discussed: the collection of healing miracles of Epidauros (IG $I^{2}$ 1, 121-123), Lebena (I.Cret. I xvii, 9, 11, 12, 14, 20), and Rome (IGUR 148); individual records of healing miracles in Athens (IG II ${ }^{2}$ 4514), Epidauros (IG IV $\left.{ }^{2} 1,125-127\right)$, Khvasa (Pontos, L. RoberT, Études Anatoliennes, Paris, 1937, p. 385), Lebena (I.Cret. I xvii, 17-19), Ephesos (SEG XLI 966), Kibyra (Études Anatoliennes, p. 384-387), Lydia (BIWK 1; TAM V 1, 461b), Pergamon (SEG XXXVII 1019), and Rome (IGUR 105).

133) S. Prignitz, "Ein Helm und ein Omega aus Kalapodi (Phokis)", AfP 55 (2009), p. 414420: In a discussion of graffiti found in the sanctuary of Apollon at Kalapodi, P. mentions a

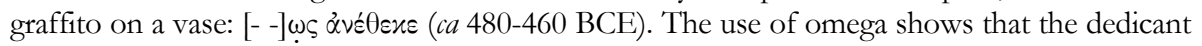
was a visitor from another (Ionian) region.

134) J.L. RAMírez SÁDABA, "La epigrafía griega hallada en la peniínsula ibérica”, in Estudios de Epigrafia Griega, p. 57-77: R. gives an overview of the Greek inscriptions found in the Iberian Peninsula. Among the texts that he presents (no inedita), a few possess religious significance: a dedication to Sarapis (and Isis?) by a man from Alexandria in Emporion (6.2.1); a dedication to the Nemeseis of Smyrna (Astorga, 6.2.2); and an amulet (6.2.9).

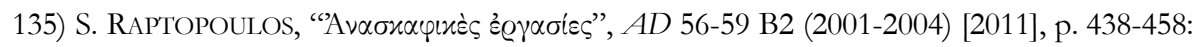
Several inscriptions are mentioned in R.'s report on archaeological work conducted in the area

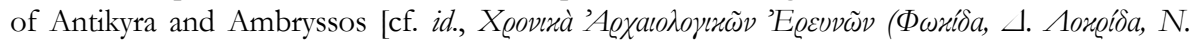

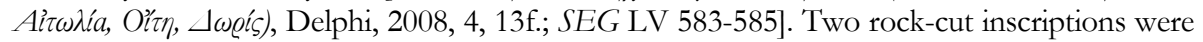
found in the area of the sanctuary of Artemis in Antikyra (p. 445f.). One of them is a dedication to Artemis Eileithyia (undated); the second text is tentatively explained as a list of offerings to Artemis. [The left column of the text seems to consist of a list of epithets of Artemis (in the nominative?). The following epithets can be recognized: Paidotrophos, Soteira, Eileithyia, Agrotera, Orthia; for such lists cf. EBGR 2008, 69 on Milet VI 3, 1395]. A defixio on a lead tablet was found in a cemetery in Antikyra, but only a few letters are preserved (p. 439). A small column in Ambryssos (p. 446) supported a dedication to Artemis and Prometheus:

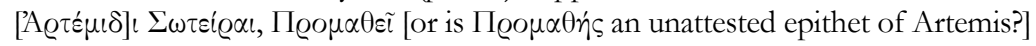

136) J. REYNOLDS - C. RoueChÉ, "The Inscriptions", in F. IșIK, Girlanden-Sarkophage aus Aphrodisias, Mainz, 2007, p. 147-192 [SEG LVII 1012-1033]: The catalogue of 215 sarcophagi from Aphrodisias (2nd-3rd cent. CE) includes 41 inscribed monuments, some of which are edited for the first time (marked with an asterisk). The texts often contain regulations

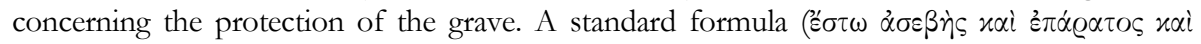

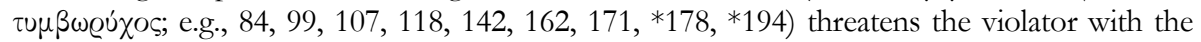

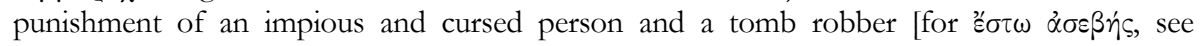


A. Delli PIZZI, "Impiety in Epigraphic Evidence", Kernos 24 (2011), p. 59-76]. In some cases, the recipient of the fine for the violation of the grave - or a part thereof - is the sanctuary of Aphrodite $(6,84, * 100, * 101, * 104, * 116,171,173, * 178, * 179)$. The use of the fine is sometimes specified: the erection of statues of the emperors (*100, 171: घis $\tau \varepsilon \mu \dot{\alpha} \varsigma \tau \tilde{\omega} \nu$

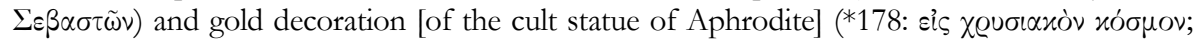

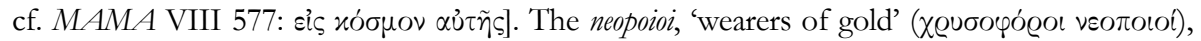
receive the fine together with the goddess (84). In nos. 100 and 116, R.-R. read ire $\dot{\alpha} \theta \varepsilon \tilde{\alpha}$

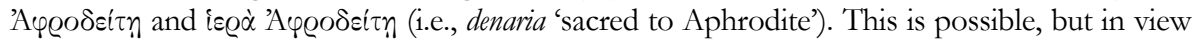

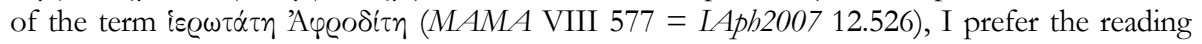

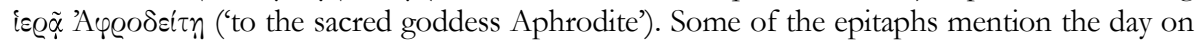
which the disposition of the grave's owner was deposited in the archive, thus providing information on the calendar of Aphrodisias. Three systems were used at the same time: the traditional Macedonian calendar, a calendar in which the months were numbered (first, second, etc.), and a system in which months (all the months?) were named after emperors (e.g.: *178:

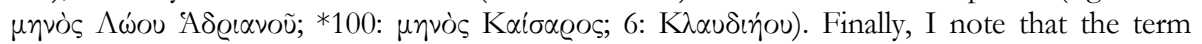

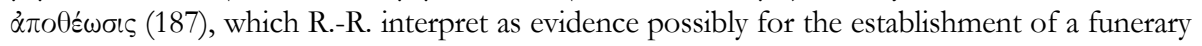
cult at the tomb, is only a euphemism for death; cf. SEG LVII 1188 lines 28/29].

137) M. RicL, "Newly Published and Unpublished Inscriptions for Hosios and Dikaios and their Contribution to the Study of the Cult", in Festschrift Schwertheim II, p. 563-579: R. presents 58 inscriptions concerning the cult of Hosios (kai) Dikaios (rarely called Hosion Dikaion) not included in her previous survey of relevant inscriptions (see EBGR 1991, 204 and 1992, 185); almost all of these texts have already been presented in EBGR. The addenda do not change the conclusions in R.'s earlier articles. The cult was primarily diffused in Phrygia, northeast Lydia, and Mysia, and is mostly known from private dedications in fulfilment of vows. These deities were associated with Mes, Helios, Apollon, and Zeus. One of the new texts (MAMAX 25) now also attests the goddess Hosia Dikaia. Her catalogue mentions several unpublished texts $(3,11-18,20,32-34,38,42)$ [32-33 have now been published: G.H.R. HORSLEY, The Greek and Latin Inscriptions in the Burdur Archaeological Museum, London, 2007, nos. 19, 90-91; see also 92-93; see EBGR 2008, 70]. Information is provided on inedita from Dorylaion: two

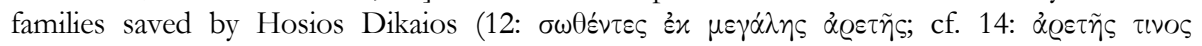

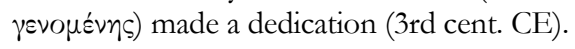

138) K.J. RigsBy, “Notes on Sacred Laws”, ZPE 170 (2009), p. 73-80 [BE 2010, 8, 253]: 1) A bronze tablet from the Heraion of Argos (6th cent.; IG IV 506; KOERNER, Gesetzestexte 29) forbids the destruction of the inscription ("if anyone either erases or damages this text that is most sacred to Hera"). In view of the common use of the expression $\dot{\alpha} \varrho \dot{\alpha} \varsigma$ है $\chi \varepsilon v \nu$, R. proposes

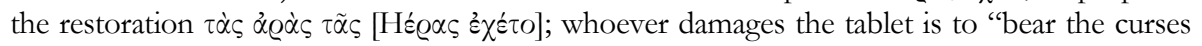
of Hera". The curse is not uttered by the goddess but calls upon Hera to execute it (cf. Plato, Leg., 881d on "the curse of Zeus"). 2) A decree from Lagina stipulates honors for Leros, a benefactor, and the establishment of a cult of the daimon of Leros, probably within the precinct of Hekate (SEG LII 1064; EBGR 2002, 131, late 4th cent.). R. presents an improved edition: "[--] being piously disposed toward the divine [--] to proclaim them as their benefactors at each

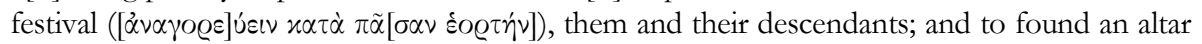

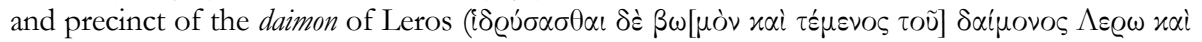
$[--])$ and [-- on the altar Leon the priest is to sacrifice a ram each year, as Kosinas also did

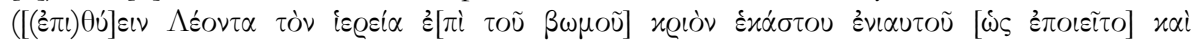

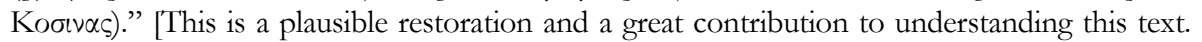
Since the honors were for both Leros and (as R. assumes) his wife, perhaps the altar was set up for the cult of the daimon of Leros and his wife, whose name should be restored in line 6. I find the last lines strange. Kosinas cannot be Leon's predecessor, since the cult and the altar have 
yet to be established. Since Kosinas is both a male and a female name (both genitive and

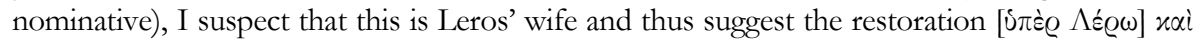
Koбıvac. Leon, obviously a priest for life, should offer an annual sacrifice of a ram "for the wellbeing of Leros and Kosinas".] 3) A cult regulation from Magnesia on the Maeander details the obligations of the priest of Sarapis (LSAM 34; RICIS II no. 304/701; 2nd cent.). According to R.'s restorations, the text obliges the priest to establish an altar for the cult (and

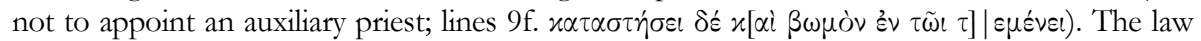

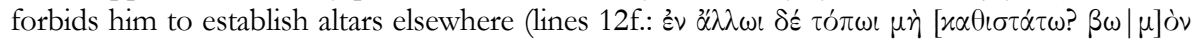
$\left.\sum \alpha \varrho \alpha \dot{\pi} \iota \delta \circ\right)$. 4) In the lex sacra of Lampsakos for the cult of Asklepios (I.Lampsakos 9, 2nd cent.) R. restores the clause concerning the offering of incense as follows (lines 19f.): $\delta$ d

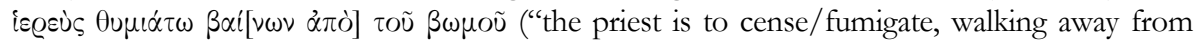
the altar") [for prescriptions of a specific route to be followed by the cult personnel, cf. a lex

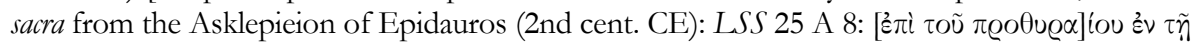

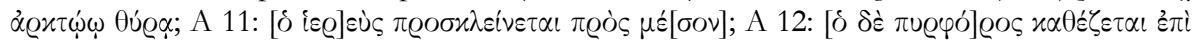

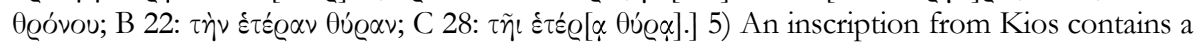
metrical lex sacra (LSAM 6; I.Kios 9), probably an oracle of Apollon Klarios, explaining the duties of the participants in the cult of a goddess: "You are all to accompany the basket unshod and in clean clothes, but leave your gold at home, for this she (the goddess) heartily

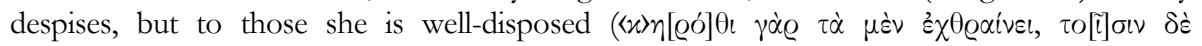
$\pi \varrho 0 \sigma \alpha[0] \delta \tilde{\alpha})^{\prime}$. [The reading and interpretation of the last line is uncertain; $L S A M$ has $\lambda \tilde{\eta} \varrho o เ \gamma \alpha \dot{\alpha} \varrho$

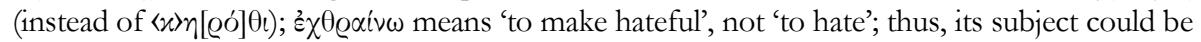
$\tau \dot{\alpha} \chi \varrho \cup \sigma i \alpha$. Finally, $\tau 0[\tilde{i}] \sigma \iota \nu \delta \varepsilon \grave{\varepsilon} \pi \varrho O \sigma \alpha[u] \delta \tilde{\alpha}$ is a very uncertain reading. Accepting Sokolowski's $\lambda \tilde{\eta} \varrho o r ~ \gamma \alpha \dot{\alpha} \varrho$ and taking $\pi \varrho o \sigma \alpha u \delta \alpha \dot{\alpha} \omega$ to mean 'speak of, I attempted the translation, "Leave the gold jewels at home; for they are an expression of silly vanity; they make some people into enemies, they cause the gossip of others" (A. CHAniotis, "Dynamic of Emotions and Dynamic of Rituals. Do Emotions Change Ritual Norms?”, in C. BROSIUS - U. HÜSKEN, eds, Ritual Matters: Dynamic Dimensions in Practice, London, 2010, p. 208-233); yet, I admit that this is

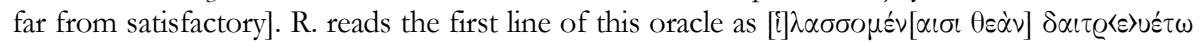

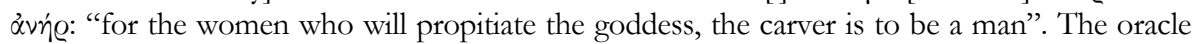
justifies the exceptional presence of a man in a female cult, during the sacrifice.

139) A. Robu, "Le culte de Zeus Meilichios à Selinonte et la place des groupements familiaux et pseudo-familiaux dans la colonisation mégarienne", in Norme -- religieuse, p. 277-291 [BE 2010, 346]: Adducing the evidence for the existence of patriai (groups based on true or fictive kinship) in Megara and in Megarian colonies (Selinous, Byzantion), R. argues that such groups played an important role in the colonization of Megara and Herakleia. In the process of colonization, the kinship cults of Dionysos Patroios and Zeus Meilichios were exported to the colonies, together with the poliadic cults of the mother city.

140) C.E. RÖMER, "Gebet und Bandzauber des Severus von Antiochia gegen den Biss giftiger Tiere, oder: Maltomini hatte recht”, ZPE 168 (2009), p. 209-212: As F. Maltomini has shown (EBGR 2007, 89) the magical papyrus PMG 12 does not contain the spell of the wandering uterus, but a spell against the bite of poisonous animals and insects. R. points out that this interpretation is now confirmed. New fragments of this papyrus contain the label of the text: it

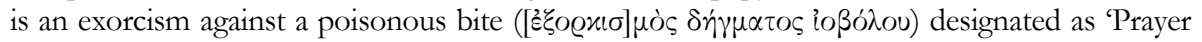
of St. Severus, patriarch of Antioch' (who died in exile in Egypt). R. presents a new edition of the text.

141) L. RusCu, “Apollo Agyeus in Mesembria”, Kernos 22 (2009), p. 125-132 [BE 2010, 449]: Combining archaeological, numismatic, and epigraphic evidence from Mesambria and its fort 
Anchialos, R. argues that Apollon, the patron of Mesambria, was worshipped as Agyeus, a guardian of gates, averter of evil, and patron of migration.

142) M. SÁnChez OrTiz de LANDALUCE, "Elementos míticos en el epigrama inscripcional", in Estudios de Epigrafia Griega, p. 205-217. S. studies the use of mythical exempla in Greek votive, commemorative, and funerary epigrams, rare in the Archaic period, and more common later.

143) E. SANZI, "La trasmissione dei sistemi religiosi complessi nel secondo ellenismo. Qualque esemplificazione dall'XI libro de le Metamorfosi di Apuleio", in C. BONNET - S. RIBICHINI D. Steuernagel (eds), Religioni in Contatto nel Mediterraneo Antico. Modalità di diffusione e processi di interferenza, Pisa, 2008 (Mediterranea, 4), p. 33-48: In a study dedicated to the transmission of religious ideas in the Roman Empire, S. discusses the diffusion of the Egyptian cults. He comments in particular on the similarity between the praise of Isis in Apuleius' Metamorphoses $\mathrm{XI}$ and the aretalogies of Isis from Kyme (I.Kyme $41=$ RICIS 302/0204) and from Maroneia (I.Aeg.Thr. E205 = RICIS 114/0202) [cf. supra no. 119]. He also discusses the importance of banquets for the initiates in the cults of Isis and Sarapis.

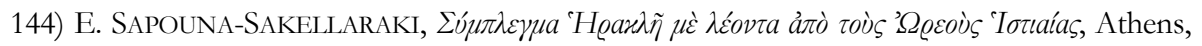
2009 [BE 2011, 343]: S. publishes a sculptural group showing Herakles engaged in combat with a lion (the lion of Nemea), probably the work of a Naxian artist. It was found in Oreoi/Histiaia (Euboia, ca 575-550). A dedicatory inscription indicates that there was a cult of Herakles at this site. She associates the cult of Herakles with his relation to water and hot springs. The inscription, studied by C.B. KRITZAS, ibid., p. 136-138, reads Quגiov ảvé $\theta \varepsilon x \varepsilon v$.

145) V. SCHILD-XENIDOU, Corpus der boiotischen Grab- und Weibreliefs des 6. bis 4. Jahrbunderts v.Chr. (Athenische Mitteilungen, Beiheft 22), Mainz, 2008 [BE 2009, 244; SEG LVIII 427, 446, 483]. S.-X. studies the typology and chronology of the Boiotian dedicatory and funerary reliefs of the 6th-4th cent. BCE. She also gives an overview of the representations, including those of priestesses (p. 172-174), hero riders (p. 192-194), funerary banquets (p. 196-203), deities (p. 204-233: Kybele, Pan, Herakles, Demeter, Herakles and Demeter, Aphrodite, Dionysos and a goddess, Artemis, Zeus Meilichios, and Agathos Daimon), hero riders, funerary banquets, and gods (p. 159-233). Some of the 127 stelai in the catalogue (235-338) are inscribed. The dedications (p. 157f.) include votives offered to Pan $(69=$ I.Thespiai 315), Herakles $(72=I G$ VII 246; 82), Aphrodite Euakoos (74 = SEG XXXI 515), Agathos Daimon (111 = I.Thespiai 220), the hero Aleximachos (86, from Tanagra). An interesting ineditum of unknown provenance $(114$, ca 330-320) is a votive relief with the representation of a standing young female figure wearing a diadem on her head, according to X.-S. a priestess. [The text suggests that this is the representation of a goddess; Eutychides made his dedication in response to a

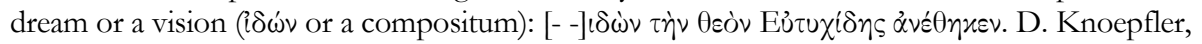

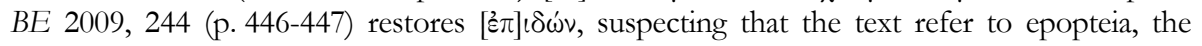
ultimate degree of initiation; in that case the goddess is Kore; an origin from Eleusis cannot be excluded.]

146) S. SCHEuble, "Inschriften aus Schedia", Chiron 39 (2009), p. 463-503: Ed. pr. of 33 new and re-publication of four already known inscriptions found in Schedia $(30 \mathrm{~km}$ south of Alexandria). The known texts consist of two plaques [for the covering of altars] naming Athena Polias and Zeus Soter (1-2, late 4th cent.), the dedication of a sanctuary of Kleopatra (the deified Kleopatra III?) by soldiers (4, late 2nd cent.), and an inscription commemorating the opening of a canal named Agathos Damon (6, 80-81 CE). The new texts include a dedication to Sarapis and his synnaoi made by a woman and her children for the wellbeing of Augustus, who is identified with Zeus Eleutherios (restored; 5, ca 7 BCE). The dedication was 


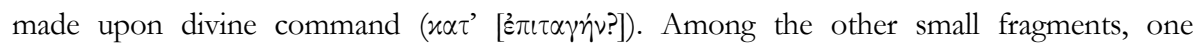
recognizes a dedication $(18,2 \mathrm{nd} / 3 \mathrm{rd}$ cent. $\mathrm{CE})$, a reference to an altar (19, Imperial period), and a reference to Aphrodite or a theophoric name deriving from the goddess (32).

147) S. SCHMidT, "Zum Treffen in Neapel und den Panhellenia in der Hadrianinschrift aus Alexandria Troas", ZPE 170 (2009), p. 109-112 [BE 2010, 236]: The date of the introduction of a new cycle of agonistic festivals by Hadrian, mentioned in his letter found in Alexandreia/Troas [EBGR 2007, 111], depends on the date of the emperor's meeting in Naples with the Dionysiac artists and with representatives of the cities that organized agonistic festivals. This meeting was dated in August $134 \mathrm{CE}$, during the celebration of the Sebasta. S. proposes an earlier date (late summer of 133). Consequently, the new cycle was initiated in 133 (the 228th Olympiad) and the first celebration of the Panhellenia was in 137.

148) S. SCullion, "Sacrificial Norms, Greek and Semitic: Holocausts and Hides in a Sacred Law of Aixone", in Norme -- religieuse, p. 153-169 [BE 2011, 225]: A new fragment of a cult regulation from Aixone in Attica (EBGR 2004, 256) lists the funds provided to priests and their share of the sacrificial animal. The new fragment, which concerns 'chthonic' sacrifices (to Hagne Thea and heroes), does not contain any mention of 'double portions' of meat or meat to be placed onto the table; consequently, the sacrifices must have been holocaust sacrifices

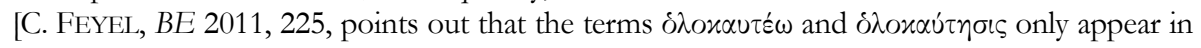
fairly late texts]. And yet, the officiating priest obtained the hide as a perquisite. From this, as well as from Hebrew and Punic parallels, S. convincingly infers that it was normal in Greek holocaust sacrifice to flay and cut the victim before incinerating it in sections on the altar. Further evidence for this practice is indirectly provided by a regulation concerning the cult of Herakles in Thasos (LSCG Suppl. 63: prohibition of cutting of perquisites in this particular holocaust) and the cult calendar of the deme of Erchia in Athens (LSCG 18), which stipulates the burning of the skin of a goat, thus forbidding an (otherwise usual) perquisite. This evidence is consonant with a polar distinction between Olympian and chthonian sacrifices and mixed rites existing along a continuum between them.

149) H. SiARD, "L'analyse d'un rituel sacrificiel dans le Sarapieion C de Délos", in Sacrifice antique, p. 27-38. S. studies the archaeological remains associated with an altar in the Serapieion C. On the basis of the epigraphic evidence concerning this cult place, she argues that the sacrifices offered on this altar were part of a 'medical ritual'. The medical aspects of the cult are

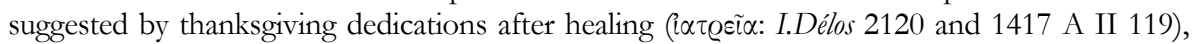
references to dream interpreters (ỏveıon@ĩ $\alpha$ : I.Délos 2071, 2105/2106, 2120, 2151, 2619 b 10), and anatomical votives (e.g. I.Délos 1417 B I 46 and 50). Dedications to Isis-Hygieia (I.Délos 2060) and to Asklepios (e.g. I.Délos 2384) have been found there. The altar was located

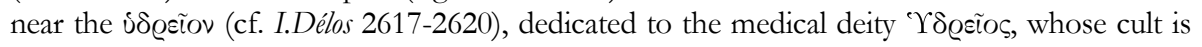
attested only in this sanctuary (e.g. I.Délos 2155 and 2160).

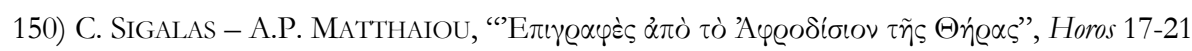
(2004-2009), p. 473-480 [BE 2010, 478; SEG LVIII 836-838]: Ed. pr. of three inscribed vases found in the sanctuary of Aphrodite in Thera (6th-4th cent.). Two inscriptions designate the

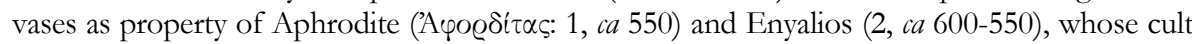
was obviously connected with that of Ares and Aphrodite. The third text mentions in the

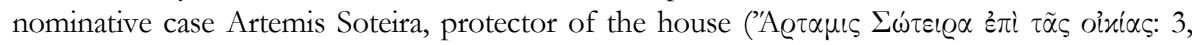
late 5 th/early 4 th cent.).

151) K. Sismanidis, "Catalogue of Exhibits", in P. Adam-Veleni (ed.), Kalindoia: An Ancient City in Macedonia, Thessalonike, 2008, p. 92-200: S. presents a catalogue of the exhibits in a temporary exhibition dedicated to Kalindoia (Archaeological Museum of Thessaloniki, February 
2008-January 2009). These exhibits include numerous inscriptions, most of them published: a list of the priests of Asklepios from 334 to 304 BCE (1 = SEG XXXVI 626); an honorific decree for the priest of Zeus, Dea Roma, and Augustus in 1 CE (8 = SEG XLII 579; EBGR 1992, 92); the building and dedicatory inscriptions of the Sebasteion $(23=$ SEG LIV 606; EBGR 2004, 251; 24 = SEG XLII 588; EBGR 1992, 92); dedications to Hermes (45) and to Apollon Pythios and Artemis Hagemona (47; SEG LXII 585/586; EBGR 1992, 92); a dedication to Demeter $\varkappa \alpha \tau^{\prime}$ ह $\pi \tau \tau \alpha \gamma \eta \dot{v}$ (SEG XLV 770). We focus on the new texts. The members of an elite family dedicated an exedra, a stoa, and the bouleuterion, which was part of the building complex of the Sebasteion; one of the dedicants served as priest of Zeus, Dea Roma, and

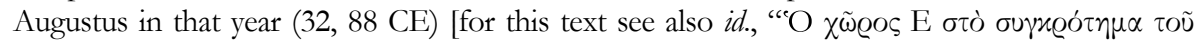

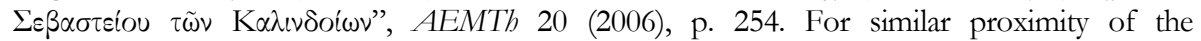
bouleuterion to the temple for the imperial cult, see the building excavated in Lyttos on Crete and its inscriptions; EBGR 1992, 45]. Lanasa made a dedication to the Babylonian goddess

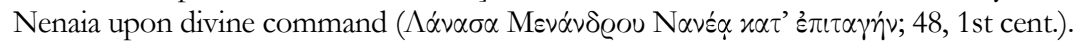

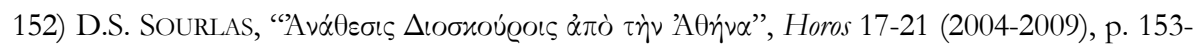
158 [BE 2011, 219]: Ed. pr. of a dedication to the Dioskouroi (Athens, ca 150-100), possibly from the sanctuary of these gods (Anakeion).

153) G. STAAB, "Epigramm auf eine Nemesisweihung und Sonnenuhr aus Oinoanda", EA 42 (2009), p. 135-141 [BE 2011, 566]: Ed. pr. of a fragmentary dedicatory epigram that commemorates the dedication of a statue of Nemesis and a sundial in the gymnasium by an 80-year-old

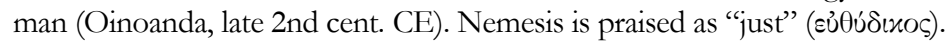

154) E. StafFord, "Cocks to Asklepios: Sacrificial Practice and Healing Cult", in Sacrifice antique, p. 205-221: After surveying the archaeological, literary, and epigraphic evidence of sacrifices to Asklepios (esp. LSCG 60, 159; IG II2 974), S. concludes that Asklepios received sacrifices of a whole range of animals (birds, sheep, pigs, cattle), but not goats. The sacrifice pertained to the type usually offered to gods: a blood sacrifice followed by feasting, although sometimes a bolokautesis is attested as are restrictions concerning the consumption of meat.

155) A.B. StAllsmith, “The Name of Demeter Thesmophoros”, GRBS 48 (2008), p. 115-131: After giving an overview of cult epithets of Demeter and of various interpretations of the epithet Thesmophoros, attributed to Demeter and Kore, S. raises serious objections to the interpretation of this epithet as referring to objects carried during the festival of the Thesmophoria. The celebrants are thesmophoriazousai not thesmophoroi; unlike the Oschophoria (there is no Apollon Oschophoros) or the Arrephoria (there is no Athena Arrephoros), the epithet refers to the goddess and not to the rites of the festival. Other epithets of Demeter include Pyrphoros, Malophoros, Karpophoros, and Horephoros. The epithet refers to agriculture and its secret rituals. In Arkadia, a telete was celebrated in the temple of Demeter Thesmia.

156) M. Stankovska-Tzamali, "Trois nouvelles inscriptions honorifiques de la Macédoine septentrionale (Stuberra). Notes prosopographiques”, REA 111 (2009), p. 115-125: Ed. pr. of an honorific inscription for Septimia Silvane Kelereine, daughter of a Makedoniarches, Septimius Silvanus Celer, and his wife, the high priestess of the imperial cult, Lucia Aurelia Trevonia Nikomacha (Styberra, 3rd cent. CE); the imperial cult is attested in Styberra (IG X 2, 2, 322). [The fact that Nikomacha was the wife of a Makedoniarches, who also served as the provincial high priest, suggests that Nikomacha was high priestess of the provincial, not the local imperial cult.] Her paternal uncle, Silvanus Claudianus, had also served as Makedoniarches.

157) E. Stavrianopoulou, "Norms of Public Behaviour Towards Greek Priests: Some Insights from the Leges Sacrae", in Norme -- religieuse, p. 213-229: S. examines how cult 
regulations prescribe measures in order to protect the rights, privileges, and authority of priests. A regulation concerning the priesthood of the Egyptian gods from Priene (I.Priene 165; LSAM 36; ca $200 \mathrm{BCE}$ ) provides for the service of an Egyptian ritual expert; when no such expert was available, only the priest had the right to perform a sacrifice; this was strictly forbidden to inexperienced individuals. In Pergamon, a regulation concerning the priesthood of Asklepios (I.Pergamon II.251; LSAM 13; late 2nd cent.) stipulates that the priesthood is to be a privilege of Asklepiades and his descendants; the hereditary character of the priesthood was confirmed under oath by the city's magistrates. The cult was probably founded privately by an ancestor of Asklepiades and was later transformed into a public cult. Measures to protect the priesthood are also attested in Kalchedon (e.g. I.Kalchedon 10; LSAM 5). In Pisidian Pednelissos, the person of the priestess was protected from insults ( $L S A M 79$ ). The purpose of all such measures was to reinforce the authority of ritual specialists.

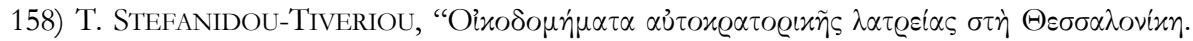

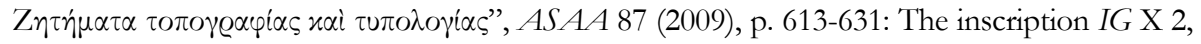

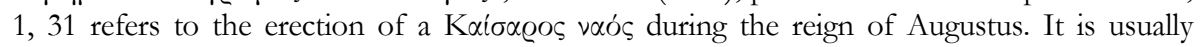
thought that the temple was dedicated to the cult of Caesar, although it has been suggested that the temple was erected for the cult of Augustus. The temple's location is not known (the eastern part of Thessalonike?). The imperial cult was also practiced in an Ionic temple north of the Serapieion (during the reign of Hadrian), possibly at the site of the earlier worship of Roma and Zeus Eleutherios. One or two further temples (under the Flavians and under the Severans) may have existed in the Forum.

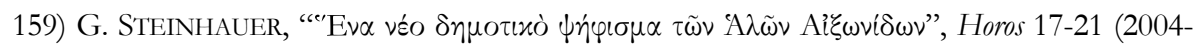
2009), p. 69-72 [BE 2011, 226]: Ed. pr. of a decree of the Athenian deme Halaieis (338/7 $\mathrm{BCE}$ ), which provides some information on the cultic life and the finances of the deme. The deme honors the treasurers for their service, for offering sacrifices to all the gods and heroes, and for giving to the hieropoioi the surplus from the deme's budget (338 drachmai).

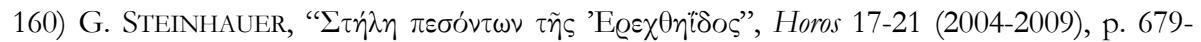
672: Although this text is only indirectly connected with religion (with the funerary cult), we mention it because of its great significance. A stele found in the villa of Herodes Atticus in Eua (Loukou [Kynouria]) contains an epigram referring to the Persian Wars and a list of the war dead from the tribe Erechtheis. This stone is the original grave inscription set up for the dead from the battle of Marathon, erected in their polyandreion. Presumably, this polyandreion supported 10 stelai, one for each tribe. Due to Herodes Atticus' antiquarian interests, the orator had the inscription (and probably the other 9 stelai) transported to his villa. The Athenian orator, who owned land in Marathon, must have demolished the old grave.

161) C. TANRIVER, “Three New Inscriptions from Tripolis”, EA 42 (2009), p. 81-86: Ed. pr. of two honorific inscriptions for victorious athletes that were found in Tripolis (Lydia, late 2nd cent. CE) [mentioned by A. ERDOĞAN - U. ÇÖRTÜK, "Tripolis Kazısı 2007 yllı çalişmaları", KST 30.4, p. 137]. The first text honors M. Aurelius Menandros, who won the boxing contest during the first celebration of the agonistic festival of Megala Attalianeia Olympia ( $\tau \dot{\nu} \nu \pi \varrho \omega \dot{\tau} \tau \varsigma$

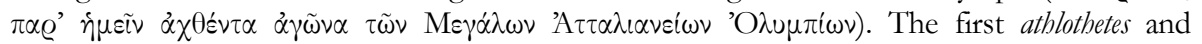
agonothes for life was M. Aurelius Attalianos, obviously the founder of the festival. The sponsor

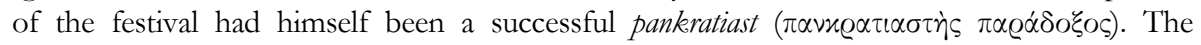
festival was connected with the cult of Zeus Olympios. The second inscription honors two boxers, who competed in the same festival in the same year; their combat ended in a draw

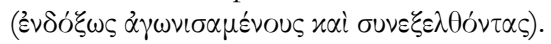




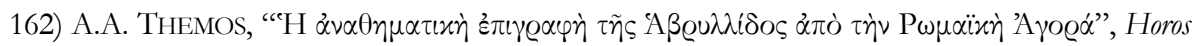
17-21 (2004-2009), p. 147-152 [BE 2011, 220]: Ed. pr. of the honorific statue of a priestess of Demeter and Kore, Habryllis (Athens, late 3rd cent.). She was already known as a priestess from $I G \mathrm{II}^{2} 3477$, and $I G \mathrm{II}^{2} 6398$ is her epitaph. Her statue was dedicated by her relatives, who included the most influential Athenians of the late 3rd cent., Mikion and Eurykleides.

163) G. THÉRIAUlt, "Quelques remarques sur le culte d'un magistrat romain à Thespies", ZPE 168 (2009), p. 183-186 [BE 2010, 292]: T. discusses the cult of Theos Tauros in Thespiai (I.Thespiai 72-80). This deified Roman benefactor cannot be Statilius Taurus, consul in 11 and 16 CE; such a cult of a prominent Roman senator would be impossible during Augustus' principate. The member of the family of the Statilii Tauri who received cultic honors in Thespiai cannot be identified with certainty.

164) J.B. Torres, "El himno de Epidauro a la Madre de los Dioses: epigrafía e intertextualidad", in Estudios de Epigrafia Griega, p. 239-247: T. studies the composition of the Epidaurian hymn to the Mother of the Gods (IG IV 2.1.131). He recognizes an aposiopesis in the dialogue between the goddess and Zeus (lines 15-18). This may be explained as the result of a semidramatic performance of the hymn. The hymn also bears some resemblance to the second stasimon in Euripides' Helena. Although the hymn follows the traditional structure of this genre, it introduces new elements.

165) N. Trippé, "Les épiclèses d'Artémis à Milet-Didymes: quelles offrandes et quels donateurs pour les différentes facettes de la déesse?, in Donateur, offrande, déesse, p. 273-285: Artemis had several epikleseis in Miletos and Didyma, which T. attempts to associate with different aspects of Artemis: Pythie was connected with public life; Boulaia was the patron of the council; Epipyrgidia was associated with the protection of the city; Chitone derives her name from the ritual offering of garments by young individuals; Lochie was a patron of birth; Lykeie is the female form of (Apollon) Lykeios. Patmia, related to rites on Patmos, may be the result of developments in the Roman period.

166) F. TROTTA, "A proposito delle due dediche della stoà orientale", in Iasos in età romana. Miscellanea storico-archeologica, Ferrara, 2008, p. 7-15 [SEG LVIII 1212]: T. publishes some fragments belonging to the dedicatory inscriptions of the stoa of the East Agora of Iasos (I.Iasos 8 and 254, 135/6 and 138 CE). The stoa was dedicated to Artemis Astias and to the emperor (Hadrian and Antoninus Pius, respectively).

167) C. Tuplin, “The Gadatas Letter”, in Greek History and Epigraphy, p. 155-184: T. discusses the language of the letter of Dareios I to Gadatas that concerned the privileges of a sanctuary of Apollon in Magnesia on the Maeander (I.Magnesia 115), arguing that the formulations used can be reconciled with an authentic letter [but see supra no. 88bis]. As concerns the cult of Apollon, probably at Aulai, T. expresses doubts about whether the ritual described by Pausanias (X, 32, 6), according to which 'holy men' leapt from cliffs, rocks, and uprooted trees, already existed in the Archaic period, when the letter [if authentic] was written. The cult place of Apollon in Aulai might have been an oracular site. The exact context of letter's authorship cannot be determined with certainty: Instead of supporting asylum or other rights, it could have been inscribed as propaganda for a local oracle.

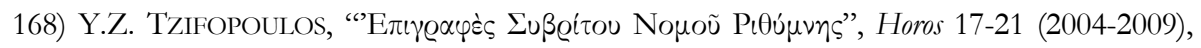
p. 567-578 [SEG LVIII 1021]: Ed. pr. of a fragmentary decree, possibly in honor of an individual (Syvritos, Crete, 3rd cent.). There is a reference to the festival Dionysia, possibly in connection with the announcement of honors. The cult of Dionysos was only indirectly attested in Syvritos. This is the first attestation of the Dionysia in this city. T. provides an overview of the cult of Dionysos in Crete. 
169) Y.Z. TZIFOpOulos, “Two Unpublished Inscriptions from the Rethymnon Prefecture”, in Estudios de Epigrafia Griega, p. 525-532 [BE 2011, 483]: Ed. pr. of a dedication of an altar to Nemesis in fulfilment of a vow, possibly in an agonistic context (area of Lappa, 1st/2nd cent.).

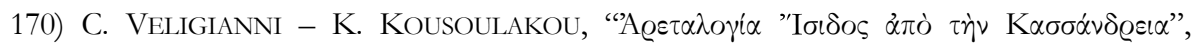

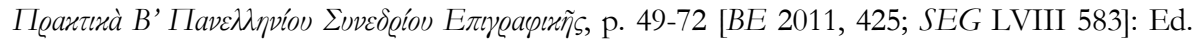
pr. of an aretalogy of Isis from Kassandreia (2nd cent. CE). The text preserves an invocation

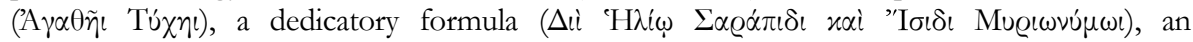
introduction stating that the text is a copy of the original in the sanctuary of Phtha in Memphis

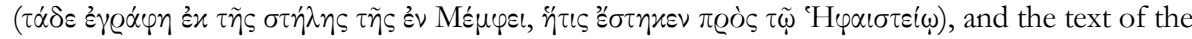
self-praise of Isis (lines 5-17). The content is very similar to that of the aretalogies of Kyme (RICIS 302/0204 = I.Kyme 41), Thessalonike (RICIS 113/0545 = IG X 2, 1, 254), and Ios (RICIS 202/1101 = IG XII 5, 14 + Suppl.). Preserved are the first 18 sections of the Isis' selfpraise contained in the copy of Kyme. The edd. pr. present detailed commentary of the content.

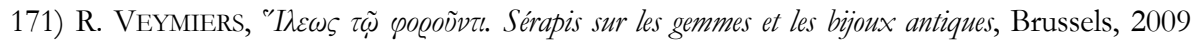
[BE 2010, 59]: V. presents an introduction to the cult of Sarapis, focusing on the iconography of Sarapis and his assimilation to Agathos Daimon, Helios, Ammon, and Zeus. The book contains a catalogue of gems, many of which are inscribed (p. 222-367). We can only briefly mention a selection of inscriptions. Most inscriptions consists of acclamations, usually of the

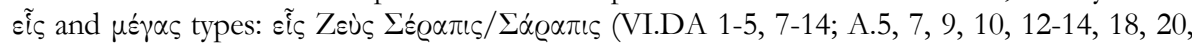

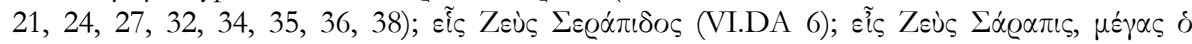

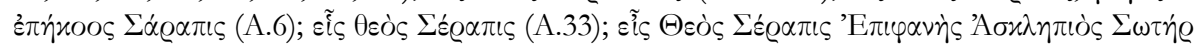

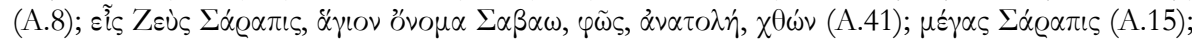

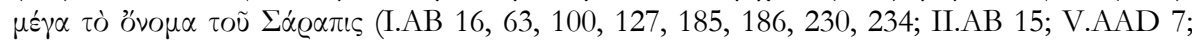

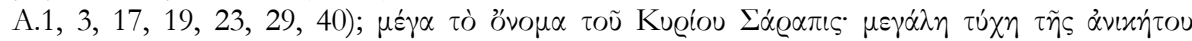

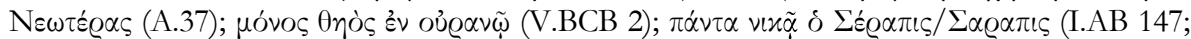

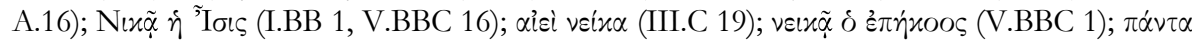

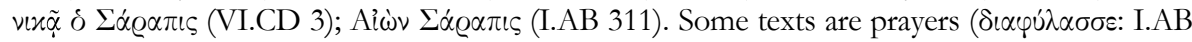

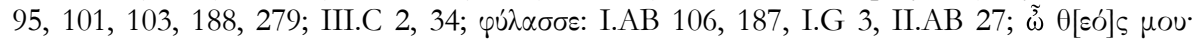

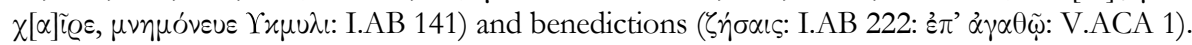
Also common are inscriptions giving the name and epithets of the god (I.AB 297; A.30; I.FC

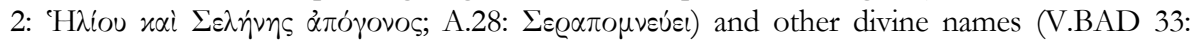

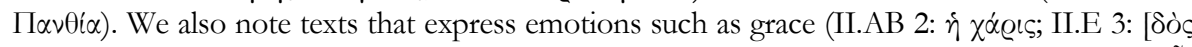

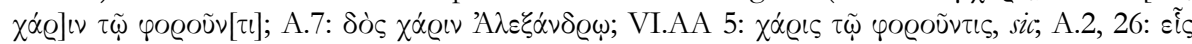

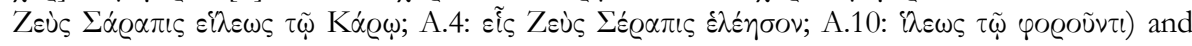
hope (I.AB 299: 'E $\lambda \pi i \varsigma$ ). Protection was the general expectation of those who wore the amulets

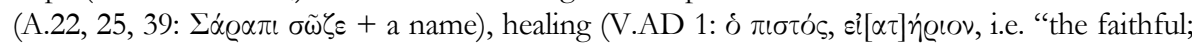

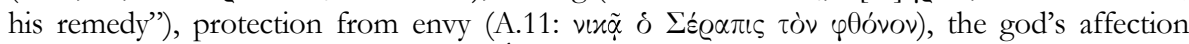

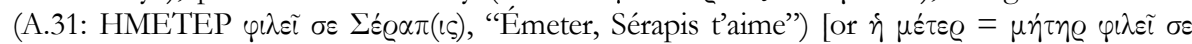
"the mother loves you; Serapis"]. There are numerous magical words, names, and formulas,

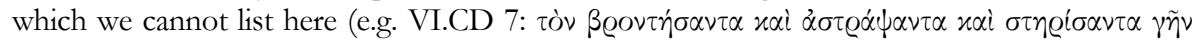

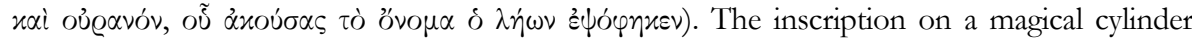
implies that it was made in accordance with an oracle (V.BCB 11: $\alpha_{\alpha} \dot{\alpha} \chi \varrho \eta \mu \alpha \tau \tau \mu$ óv) [In

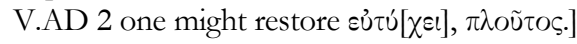

172) R. Veymiers, "Les cultes isiaques à Amphipolis. Membra disjecta (III' s. av. J.-C.-III' s. apr. J.-C.)", BCH 133 (2009), p. 471-520: V. collects the archaeological and epigraphic evidence for the cult of the Egyptian gods in Amphipolis. Their worship was introduced in the 3rd cent. BCE and continued until the 3 rd cent. CE. The epigraphic evidence consists of 11 texts (10-11 
are inedita). An epitaph mentions a priestess of Isis (1, 3rd cent.). A man made a dedication to Sarapis, Isis, and king Philip V (2, ca 200 BCE). A man who exercised the duties of a trierarches (during the navigium Isidis) was honored by the priest and the bypostoloi (5, 67/66 BCE). Other dedications are addressed to Sarapis, Isis, and Herakles (3, 2nd cent.), Sarapis, Isis, and Anubis

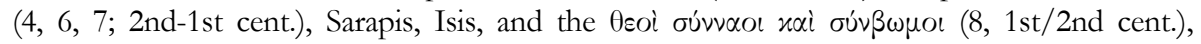
Totoes (represented as a sphinx) designated as Divine Demon and Sleep (9, 2nd cent. CE:

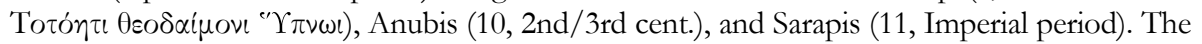
dedications were made in connection with vows (6: $\varepsilon \dot{0} \xi \dot{\alpha} \mu \varepsilon v o c)$, in fulfillment of a vow (9: $\tau \dot{\eta} v$

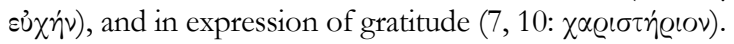

173) J. Wallensten, "Personal Protection and Tailor-Made Deities: The Use of Individual Epithets”, Kernos 21 (2008), p. 81-95 [SEG LVIII 802]: W. republishes a dedication to Isis Aphrodite Dikaia (I.Délos 2158, 169 BCE) found in the Sarapieion C. She argues that the

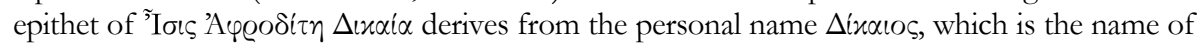

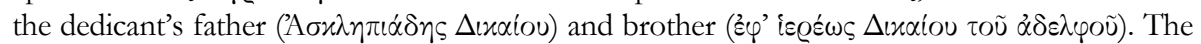
same epithet may be restored in a dedication made by Dikaios, the priest (I.Délos 2040). Isis Aphrodite Dikaia was a deity "that existed only in the context of a certain family", as its exclusive protectress; her cult was possibly introduced by a member of this family. Isis

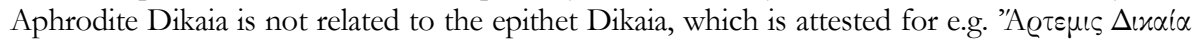

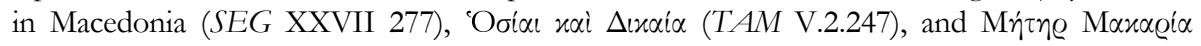
'Ooi $\alpha \Delta x \alpha i \alpha$ (MAMA X 158). In support of this interpretation, W. adduces evidence for the efforts of worshippers to assure the protection of gods and for epithets of gods that derive

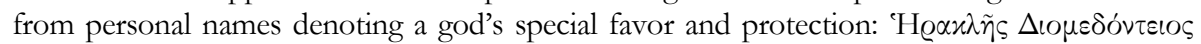

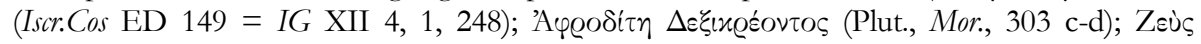

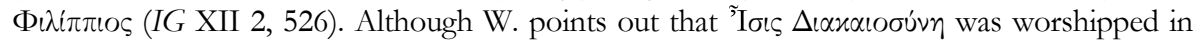
the Sarapieion C (I.Délos 2103; cf. I.Délos 2079 from an unknown context), she insists that the epithet Dikaia "does not imply a specific aspect of the goddess as much as it draws attention to a special relationship between the dedicator and the goddess. Isis Aphrodite was 'Dikaian', 'of Dikaios'. Obviously, this interpretation does not - and should not - in any way exclude that the epithet simultaneously had connotations of justice" (95). [In view of the presence of Isis Dikaiosyne in the same cult place, I find the opposite far more probable: Isis was the goddess of justice, but the members of this family certainly realized and exploited the connotations of their (not her) name. W. does not adequately consider Isis' connection with justice, clearly expressed in the Isis aretologies. She also ignores the extremely common phenomenon of adding the name of a cult's founder (in the genitive) to the name of a divinity. For such examples, see EBGR 2000, 108: Dionysos Kallonos; 2003, 31: Meter Menandrou; 2004, 177: Zeus Ariou; 2005, 46: Zeus Pharnaoua; 2006, 88: Dionysos Mousaiou; 2007, 66: Mes Tiamou, Mes Artemidorou.]

174) J. Wallenstein, "Demand and Supply? The Character of Aphrodite in the Light of Inscribed Votive Gifts", in Donateur, offrande, déesse, p. 169-180: Aphrodite received dedications in various capacities: sometimes as a patron of sexuality (anatomical votives representing genitalia) and marriage (Dosandra, Epiteleia), mostly as a patron of magistrates and seafaring. A study of dedications to Aphrodite shows that men worshipped the goddess primarily in their role as magistrates. Their dedications were often placed in public space - the agora - and not in the goddess' sanctuary. Her epithets were often connected with the office, whose occupants she was expected to protect (e.g. Nomophylakis, Stratagis). Under Roman rule, a new aspect was added to the perception of Aphrodite: the mother of Aineias and, later, the ancestor of the Julio-Claudian house. 
175) B. WICKKISER, “A Chariot for Asklepios: SEG 25.226”, ZPE 168 (2009), p. 199-201: The inscription narrating the foundation of the cult of Asklepios by Telemachos in Athens (SEG XXV 226) seems to refer to the arrival of the god $\dot{\varepsilon} \varphi^{\prime} \propto[\varrho \mu \alpha \tau o \zeta]$. The $\check{Q} \varrho \mu \alpha$ is usually translated

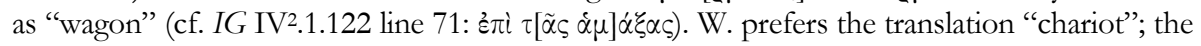
god was brought to Athens on Athena's favorite vehicle.

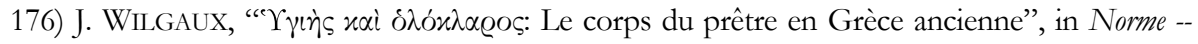
religieuse, p. 231-242 [BE 2010, 141]: After collecting the evidence provided by cult regulations concerning the physical integrity, health, and appearance of a priest, W. examines the possible reasons for the focus on the priest's body. In addition to practical reasons, this interest is explained by the perceived connection between appearance and moral qualities, as well as the view that beauty and health indicate the favor of the gods.

177) P. WILSON - A. HARTWIG, "IG I3 102 and the Tradition of Proclaiming Honours at the Tragic Agon of the Athenian City Dionysia", ZPE 169 (2009), p. 17-27 [BE 2010, 181]: IG I3 102 (the honorary decree for Thrasyboulos of Kalydon, who killed the oligarch Phrynichos) is the earliest evidence for the proclamation of honorific crowns at the City Dionysia in Athens (409 BCE). It is possible that this practice was introduced in response to this event, which had great political significance. According to the authors' restoration of the formula used in this document, the decree specified that the proclamation was to take place in the contest of tragedies. W.-H. present a list of the decrees referring to an announcement of honors at the Athenian City Dionysia with explicit reference to tragedy.

178) M. WÖRrLE, "Neue Inschriften aus Aizanoi V: Aizanoi und Rom I”, Chiron 39 (2009), p. 409-444 [BE 2010, 549]: Ed. pr. of the inscriptions on a plaque that contained a dossier with imperial letters. Two fragmentary letters of Caesar (46 BCE) concern themselves with the land belonging to the sanctuary of Zeus, probably in the context of a dispute with publicani.

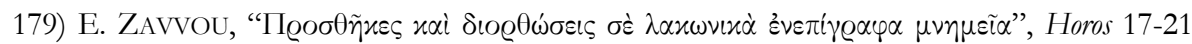
(2004-2009), p. 297-310: Z. presents new readings and interpretations of inscriptions from Lakonia. 1) A new fragment joins $I G \mathrm{~V} 1,38$ (Sparta, ca 150-200). The text is part of a list of gynaikonomoi, naming a bierothyrtes who served for the second time. 2) Ed. pr. of a dedication to Ortheia (early 5th cent.). 3) SEG XLVII 350 from Fagia is a dedication (6th cent.). 4) A new fragment of SEG XLIX 404 permits the restoration of the text as a dedication to Zeus Eleutherios Antoninus Soter (Sparta, ca 138-161). 5) Improved edition of a dedication to Poseidon from Tainaron (SEG LIII 381, 4th/3rd cent.).

180) A. Zografou, "Prescriptions sacrificielles dans les papyri magiques", in Sacrifice antique, p. 187-203: Z. presents a very good survey of sacrificial rituals prescribed in magical papyri, the

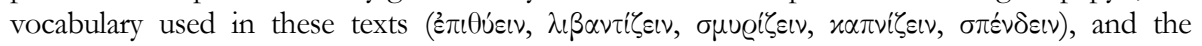
content of the sacrificial offerings. She argues that sacrifice in the papyri is not only understood

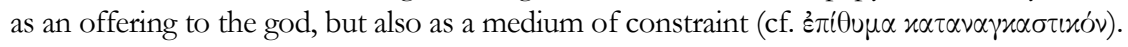

Angelos CHANIOTIS

School of Historical Studies

Institute for Advanced Study

Einstein Drive

Princeton, NJ 08540

E-mail:achaniotis@ias.edu 